UNIVERSIDADE DE SÃO PAULO

Escola de Comunicações e Artes

CAMILA LADEIRA SCUDELER RINALDI

\title{
Um olhar sobre a criação atoral e a relação com o espectador - Os filhos da Dita
}


Camila Ladeira Scudeler Rinaldi

\section{Um olhar sobre a criação atoral e a relação com o espectador - Os filhos da Dita}

Dissertação de mestrado apresentada ao Departamento de Artes Cênicas da Escola de Comunicações e Artes da Universidade de São Paulo como exigência parcial para obtenção do título de Mestre em Artes Cênicas.

Área de Concentração: Pedagogia do Teatro Formação do Artista Teatral

Orientador: Prof. Dr. Armando Sérgio da Silva

Versão corrigida. A versão original encontra-se disponível junto à Pós-graduação da ECA/USP. 
Autorizo a reprodução e divulgação total ou parcial deste trabalho, por qualquer meio convencional ou eletrônico, para fins de estudo e pesquisa desde que citada a fonte.

\section{Catalogação na publicação Serviço de Biblioteca e Documentação \\ Escola de Comunicações e Artes da Universidade de São Paulo}

Rinaldi, Camila Ladeira Scudeler

Um olhar sobre a criação atoral e a relação com o espectador - Os filhos da Dita / Camila Ladeira Scudeler Rinaldi - São Paulo: C. L. S. Rinaldi, 2011.

117 p.: il. + 2 DVDs

Dissertação (Mestrado) - Escola de Comunicações e Artes / Universidade de São Paulo.

Orientador: Armando Sérgio da Silva

1. Criação atoral 2. Biomecânica 3. Relação ator-espectador 4. Teatro épicodialético 5. Arlequins 6. Ditadura 7. Os filhos da Dita (peça de teatro) I. Silva, Armando Sérgio da II. Título 
Nome: RINALDI, Camila Ladeira Scudeler

Título: Um olhar sobre a criação atoral e a relação com o espectador - Os filhos da Dita

Dissertação de mestrado apresentada ao Departamento de Artes Cênicas da Escola de Comunicações e Artes da Universidade de São Paulo como exigência parcial para obtenção do título de Mestre em Artes Cênicas.

Aprovada em: 27 de outubro de 2011

Banca Examinadora

Prof. Dr. Armando Sérgio da Silva - Orientador Assinatura:

Prof. Dr. Alexandre Luiz Mate

Assinatura:

Prof. Dr. Reynuncio Napoleão de Lima Assinatura:
Instituição: CAC/ECA/USP

Instituição: IA / Unesp

Instituição: IA / Unesp 


\section{Agradecimentos}

Ao Professor Dr. Armando Sérgio da Silva, pela sabedoria e apoio e por ter pacientemente acompanhado meu processo de amadurecimento.

Ao Professor Dr. Flávio Desgranges, pela generosidade.

À Escola de Comunicações e Artes da Universidade de São Paulo, pela oportunidade de realização do curso de mestrado.

A todos os professores da pós-graduação da ECA cujos ensinamentos contribuíram sobremaneira com minha formação.

Aos companheiros do CEPECA que há anos vêm compartilhando da dor e delícia dos processos de criação teatral e acompanhando meus caminhos em busca da consciência do corpo político do ator.

Aos funcionários do CAC, sempre solícitos.

À Ana Maria Quintal, pela amizade, companheirismo e aprendizado constantes nesses anos de convivência.

Ao Sérgio Garcia Santiago, por me mostrar caminhos antes desconhecidos nos meandros da arte teatral.

À Marisa Quintal, Edson Frank, Alencar Ferreira, Luiz Soares, Bruno Garcia, Danielle Agostinho, Iná Camargo Costa, Ana Martins, Ivan Seixas, Paulo Eduardo Arantes, Yedda Carvalho Chaves, Luiz Carlos Scapi, Antonio Tadachi, Vinícius Carvalho, Eder Lopes, Gregory Slivar, Fábio Spila e Marcos Pinto que participaram, das mais diferentes formas, do projeto Geração AI-5 - Os filhos da Dita e somaram esforços para que se concretizasse.

Aos funcionários do Conjunto Desportivo Constâncio Vaz Guimarães, pela compreensão que sempre tiveram comigo e minha 'dupla' atuação profissional. 
Aos membros do Grupo Teatro Escambray, amigos queridos, que me servem de inspiração e cuja trajetória ainda pretendo retratar.

Aos meus pais, Regina e Wilson que, em sua sabedoria me deram espaço para trilhar meu caminho - mesmo sem muitas vezes entenderem minhas escolhas -, e são os responsáveis pela base que me sustenta.

À Cibelle, irmã e amiga que muito me estimulou durante todo o processo.

Ao Marcelo e Cinthia, meus amados irmãos, que, mesmo à distância, sempre se fizeram presentes.

À Denise, pelo apoio constante e compreensão nos longos meses em que meus livros e anotações estiveram espalhados por seu apartamento.

À Laura, Matheus, Ana Luisa, Danilo Henrique, Lívia e Diolando Luiz, meus sobrinhos amados, que sempre trazem alegria, luz e poesia à minha vida.

Ao Danilo, companheiro cuidadoso e sempre presente, pela compreensão e parceria nos caminhos da vida.

À Maria do Carmo pelas incontáveis horas de escuta.

Ao público que vem conjuntamente construindo e modificando esse processo. 
A todos aqueles que não se conformam com o estado de coisas. 
A los que creen que el artista está divorciado de una posición social, a los capaces todavía de defender el arte por el arte, a quienes piensan que la exposición de los intereses del pueblo carece de belleza, les respondemos que el arte es una forma de comunicación entre los hombres y solo cumple su misión plenamente, cuando logra plasmar en obras artísticas la época en que se produce.

Rafael González ${ }^{1}$

${ }^{1}$ GONZALEZ, Rafael. GTE - Grupo Teatro Escambray (1968-1988). Manicaragua, 1988, p. 2.

Rafael González é diretor e dramaturgo do Grupo Teatro Escambray - coletivo cubano que figura entre os grupos teatrais em atividade mais antigos da América Latina, fundado em 1968. 
RINALDI, Camila Ladeira Scudeler. Um olhar sobre a criação atoral e a relação com o espectador - Os filhos da Dita. 2011. 117 f. Dissertação (Mestrado) - Escola de Comunicações e Artes, Universidade de São Paulo, São Paulo, 2011.

\section{Resumo}

Esta pesquisa debruça-se no meu processo de criação atoral no espetáculo Os filhos da Dita, do Núcleo Arlequins da Cooperativa Paulista de Teatro, tendo como base teórico/prática principal o treinamento psicofísico proposto pelo encenador-pedagogo Vsévolod Meyerhold, buscando sublinhar as demandas e possibilidades de uma postura política consequente em cena.

A partir das relações estabelecidas desde a escolha do tema, o desenvolvimento da dramaturgia e posterior criação cênica propriamente dita, busco descrever os estímulos e motivações que me conduziram na criação cênica em diálogo com a estética desenvolvida pela companhia há 25 anos, e o posterior contato estabelecido com o espectador.

Palavras-chave: criação atoral, biomecânica, teatro épico-dialético, relação atorespectador, teatro de grupo, Arlequins, ditadura civil-militar brasileira. 
RINALDI, Camila Ladeira Scudeler. A look at an actress' creative process and relationship with the audience - Os filhos da Dita. 2011. 117 f. Dissertação (Mestrado)

- Escola de Comunicações e Artes, Universidade de São Paulo, São Paulo, 2011.

\begin{abstract}
This research lies on my acting creative process in the play called Os filhos da Dita, of Arlequins (Theatre group that belongs to the Cooperativa Paulista de Teatro), having as main theoretical/practical basis the psycho physical training proposed by pedagogue-director Vsévolod Meyerhold, aiming at underling the demands and possibilities of a consequent political posture on stage.

Based on the relationships established with various artists involved in a creative process from choosing the play theme, dramaturgy development and following scenic creation, I describe the stimulus and motives that led me in the scenic creation. The procedures are developed in open dialogue with the esthetics held by the group in the last 25 years, and subsequent contact established with the audience.
\end{abstract}

Key words: actor's creation, biomechanics, epic-dialectic theatre, actor-audience relationship, group theatre, Brazilian civil-military dictatorship. 


\section{Sumário}

1. Introdução..................................................................................................................................................01

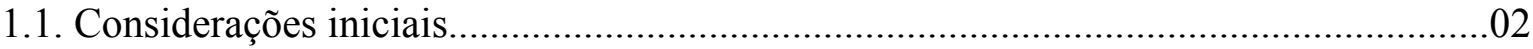

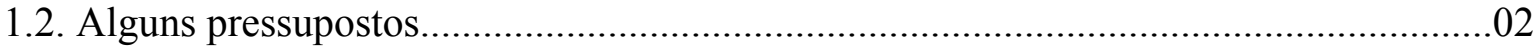

2. Atualidade e radicalidade do projeto e vivência político teatral de Vsévolod

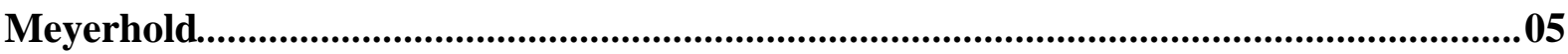

3. Processo de montagem do espetáculo Os filhos da Dita................................................18

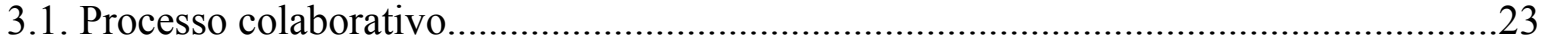

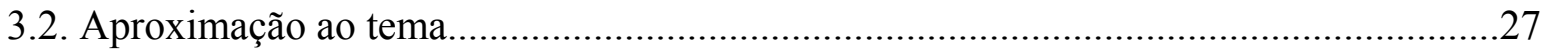

3.3. Pesquisa prática - A biomecânica no Arlequins ..........................................................28

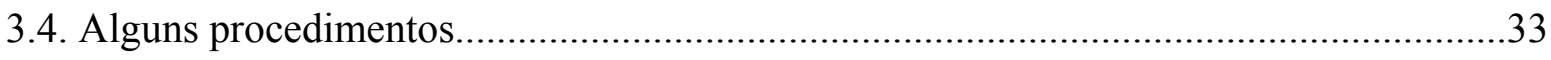

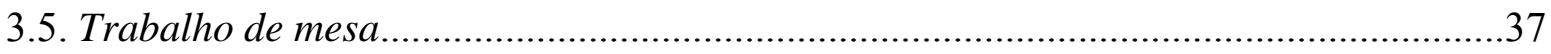

4. Nos meandros da criação atoral.........................................................................................43

4.1. Princípios e procedimentos da biomecânica utilizados na criação................................44

4.2. Descrição da criação de cenas de Os filhos da Dita........................................................49

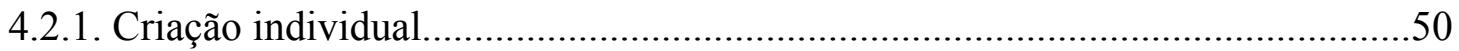

Iara

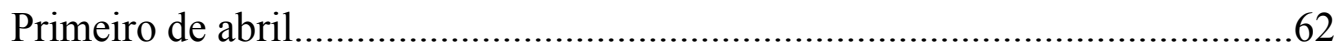

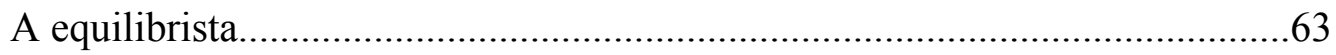

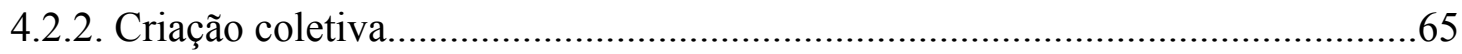

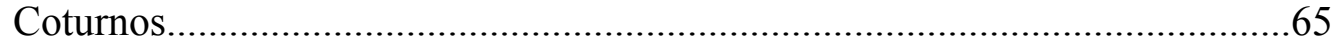

Congestionamento telefônico.....................................................................66

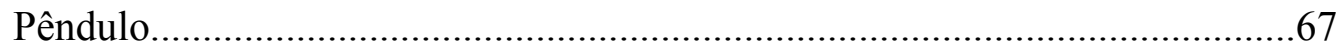

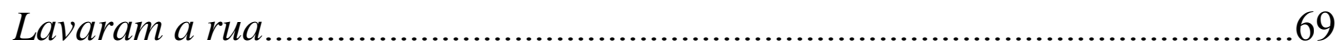

4.3. Registro fotográfico de cenas do espetáculo................................................................ 71

5. Relação ator/espectador...................................................................................................................74

5.1. Alterações a partir do contato com o público.................................................................. 78 
Bibliografia..

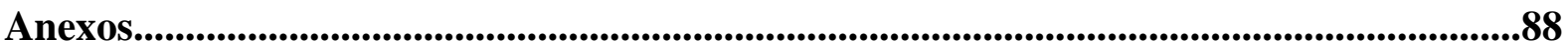

Anexo A - Ficha técnica do espetáculo Os filhos da Dita....................................................89

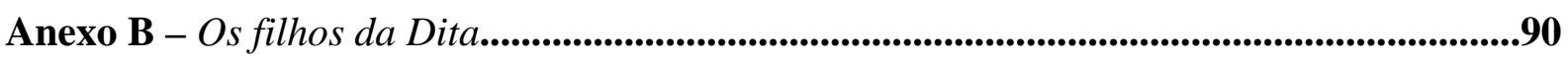

Anexo C - Lista das escolas participantes da temporada experimental de Os filhos da Dita (março a junho/2011)....................................................................................................................................115

\section{Encarte}

DVD - Registro do espetáculo Os filhos da Dita.

DVD - Um registro de olhares Arlequins sobre os filhos gerados pela Dita "dura” do nosso país (Brasil 1964-2011). 


\section{INTRODUÇÃO}

Se o homem, em sua natureza, tem a necessidade de viver em sociedade e se suas ações refletem, de alguma forma, no coletivo, pode-se concluir que o ser humano é um animal político, o que faz com que até mesmo afastar-se da política já signifique tomar uma posição de deixar que tomem decisões por si; ou seja, é também uma atitude política, uma vez que provoca consequências à sociedade. Necessário se faz, então, que se tenha consciência de que somente o viver já implica em tomar decisões, e que toda e qualquer ação influencia a coletividade.

Dalmo de Abreu Dallari ${ }^{2}$

${ }^{2}$ DALLARI, Dalmo de Abreu. O que é participação política. São Paulo: Brasiliense, 1999. 


\subsection{CONSIDERAÇÕES INICIAIS}

Descrever um processo de criação atoral ${ }^{3}$ e seus reflexos - eis o objetivo principal deste trabalho. Mas, qual o propósito de tal descrição? De que maneira as escolhas pessoais no desenvolvimento de um fazer artístico refletem um modo de ver e de se relacionar com o mundo? Ou mais, refletem um modo de inserção e, portanto, possibilidade de vislumbrar outra forma de relação entre os seres humanos?

Este trabalho busca relatar e analisar - a partir de documentação videográfica, fotográfica e escrita - a criação atoral individual e coletiva, e a relação estabelecida com o espectador no processo de construção do espetáculo teatral Os filhos da Dita do núcleo Arlequins. O recorte temporal compreende desde a definição do projeto Geração AI-5 - Os filhos da Dita ${ }^{4}$ até a estreia da peça e a temporada inicial no Teatro Coletivo em maio de 2011, na cidade de São Paulo.

A base teórico/prática principal é aquela proposta por Vsévolod Meyerhold, a partir de pesquisa e treinamento psicofísico desenvolvidos pelo encenador-pedagogo russo, buscando enfatizar as demandas e possibilidades de uma postura política consequente em cena.

\subsection{ALGUNS PRESSUPOSTOS}

Integrante do núcleo teatral Arlequins como atriz e produtora desde 2005, em 2006 iniciei pesquisa intitulada "Consciência do corpo político do ator" junto ao CEPECA Centro de Pesquisa em Experimentação Cênica do Ator da pós-graduação da ECA/USP - que tem como objetivo principal tornar consciente para o artista a dimensão político-social de seu fazer artístico. Partindo do pressuposto de que o teatro é político na medida em que trata de

\footnotetext{
${ }^{3}$ Atoral: relativo ao trabalho do ator. Ainda que seja uma palavra ainda pouco disseminada, optei por usá-la por conter o conceito de autoria do processo.

${ }^{4}$ O projeto Geração AI-5 - Os filhos da Dita busca desvendar as mazelas da ditadura, com um olhar contemporâneo sobre o golpe civil-militar de 1964, na tentativa de iluminar os acontecimentos decorrentes dessa história recente. Recuperando elementos da biografia de uma geração, descobrir uma poesia que conta a história do seu tempo, ao contar a história do homem nela. A opção por utilizar neste projeto, e consequentemente neste trabalho, o termo "golpe civil militar" - em detrimento do comumente usado "golpe militar" - deu-se por considerarmos necessário salientar que uma parcela da sociedade, representada por boa parte da elite e órgãos de imprensa, apoiou de distintas maneiras a ditadura, fato que não deve ser minimizado nem esquecido.
} 
relações sociais ${ }^{5}$, o fato do ator/atriz ter essa "consciência" possibilitará um resultado em que essas preocupações fiquem latentes e explodam para dramaturgia cênica como um todo ${ }^{6}$.

Desta feita, Meyerhold se apresenta como principal referência, em cujas proposições me baseio para desenvolver treinamento psicofísico e construir minha prática teatral. O estudo da poética planteada pelo encenador-pedagogo russo a partir de dados históricos e vivência prática ${ }^{7}$ de sua biomecânica ${ }^{8}$ - considerando as evidentes dificuldades de aproximação em razão do espaço/tempo que nos distancia -, nos permite reconhecer as inovações propostas por ele no que tange ao fazer teatral, à postura dos envolvidos na criação e na relação que se estabelece com o espectador.

O Arlequins, núcleo de trabalhadores do teatro, surge como um espaço de experimentação, compartilhamento e formação constante, em que buscamos resultados cênicos nos quais questões estético-políticas tão essenciais a mim estão presentes. Parafraseando auto definição do coletivo Dolores Boca Aberta Mecatrônica de Artes, podemos definir o Arlequins como "[...] um grupo de trabalhadores que exerce, entre todos os percalços, o direito de expressar o mundo que lhe atravessa através da arte" ${ }^{\text {" }}$ E a condição de trabalhadores que fazem arte "[...] tem total influência e consequência nas elaborações estéticas, tanto no tempo e na técnica do fazer quanto na leitura simbólica do mundo." 1011

\footnotetext{
5 Trato deste tema de maneira mais ampla no artigo intitulado "Criação do experimento cênico 'a Mulher e o Cisne': o trabalho individual na amplitude da criação coletiva - um relato", publicado no livro CEPECA: uma oficina de pesquisatores. Mas para conduzir a leitura desta dissertação de modo a evitar eventuais compreensões ambíguas acerca de minhas colocações, reproduzo aqui o trecho central deste pressuposto: “[...] ninguém, inclusive o ator, nunca é apolítico nem associal; cada um de nós é produto de seu meio, cujas linhas de força determinam a natureza do ator em suas variações individuais, sociais, históricas”. (Meyerhold apud GUINSBURG, 2001, p. 70). Enrique Buenaventura, do Teatro Experimental de Cali afirma que "[...]o teatro é político no sentido que se ocupa das relações entre os homens; esse é o tema do teatro: as relações sociais". Dentro dessa perspectiva, é necessária e esclarecedora a explicação de Iná Camargo Costa de que a distinção entre teatro/cultura e política foi estabelecida pelo capitalismo "para melhor transformar a cultura em mercadoria". E para desfazer tal imposição é necessário "recusar a distinção entre cultura e política (o que) significa entender que cultura é política e política é cultura". SCUDELER, Camila Ladeira. Criação do experimento cênico "a Mulher e o Cisne": o trabalho individual na amplitude da criação coletiva - um relato. In: SILVA, Armando Sérgio da (Org.). CEPECA: uma oficina de pesquisatores. 1. ed. São Paulo: Associação Amigos da Praça, 2010. p. 229.

${ }^{6}$ SCUDELER, op. cit., p. 229-244.

7 "A técnica de representação jamais poderá ser adequadamente entendida sem que seja praticada." In: CHEKHOV, Michael. Para o ator. São Paulo: Martins Fontes, 1996, p. XXI.

${ }^{8}$ Histórico e características da biomecânica serão apresentadas no Capítulo 2.

${ }^{9}<$ http://doloresbocaaberta.blogspot.com>

${ }^{10}$ Ibidem.

11 “" [...] para o materialismo histórico e dialético, [...] essencialmente antropocêntrico, a arte é um produto do trabalho espiritual-material humano, uma forma de conhecer, condensar e expressar aspectos de determinada visão de mundo, a partir de uma realidade histórica e socialmente datada. Desse modo, a arte, como uma forma ideológica, compõe a superestrutura social [...]." PEIXOTO, Maria Inês Hamann. A arte no cotidiano: consciência e autoconsciência. In: Anais III Fórum de pesquisa científica em arte. Escola de Música e Belas Artes do Paraná. Curitiba, 2005, p. 156-157.
} 
Nesse contexto se inserem descrição e análise de alguns procedimentos utilizados no meu trabalho como atriz na construção do espetáculo Os filhos da Dita. Este processo ocorreu a partir de constante e intenso diálogo com os demais trabalhadores da arte envolvidos na criação em seus distintos momentos: escolha do tema, o desenvolvimento da dramaturgia concomitante à criação cênica e a relação que se estabelece com o espectador a partir do momento em que o processo se abre para o olhar externo. $\mathrm{O}$ ponto de partida nesta construção foi a linguagem desenvolvida pelo grupo há 25 anos.

Importante salientar que as escolhas aqui descritas têm como base o teatro épicodialético de Brecht, que propõe uma reelaboração crítica do debate sobre o drama e a encenação épicos. ${ }^{12}$ Os pontos de demarcação do teatro épico são essenciais nesse processo que busca descrever e analisar a criação, e alguns pontos centrais da discussão merecem ser destacados: a questão da dialética não é só forma e conteúdo - é forma, conteúdo $e$ inserção na cadeia produtiva, trânsito entre palco e plateia ${ }^{13}$ : não existe arte do ator sem arte do espectador. O teatro épico busca princípios e escolhas que deem um sentido político-social à relação entre texto e cena, e a compreensão das relações desde a perspectiva proposta pela dialética nos permite compreender a afirmação de que não há distanciamento sem identificação. Como nos esclarece Anatol Rosenfeld, são duas a principais razões do teatro épico: “[...] primeiro, o desejo de não apresentar apenas relações inter-humanas individuais, objetivo essencial do drama rigoroso [...], mas também as determinantes sociais dessas relações. [...] A segunda razão liga-se ao intuito didático do teatro brechtiano, à intenção de apresentar um 'palco científico' capaz de esclarecer o público sobre a sociedade e a necessidade de transformá-la; capaz ao mesmo tempo de ativar o público, de nele suscitar a ação transformadora. O fim didático exige que seja eliminada a ilusão, o impacto mágico do teatro burguês. "14

A ênfase aqui é dada à criação atoral participativa, que busca não cair no erro histórico de tornar os principais mediadores do trânsito entre palco e plateia meros executores de uma ideia alheia e usufrui da "vantagem" de refletir acerca de um processo prático.

\footnotetext{
${ }^{12}$ Referência para o teatro moderno no tocante às relações entre experimentação formal e prática politizante, a obra de Bertolt Brecht, baseada na utilização livre e inventiva do pensamento de Marx no campo da estética, inaugura um campo de estudos - o do teatro épico-dialético - que inspira criações teatrais contemporâneas, interessadas na relação entre representação dos sujeitos e história.

${ }^{13}$ A escolha da utilização da palavra plateia dá-se com base no sentido que a mesma tem no contexto do teatro épico-dialético.

${ }^{14}$ ROSENFELD, Anatol. O teatro épico. São Paulo: Perspectiva, 2006, p. 147-148.
} 


\title{
2. ATUALIDADE E RADICALIDADE DO PROJETO E VIVÊNCIA POLÍTICO
}

\section{TEATRAL DE VSÉVOLOD MEYERHOLD}

\begin{abstract}
Arte revolucionária deve ser uma mágica capaz de enfeitiçar o homem a tal ponto que ele não mais suporte viver nesta realidade absurda.
\end{abstract}

Glauber Rocha

Passei a me interessar e buscar aprofundar-me mais acerca de V. E. Meyerhold quando identifiquei em seu trabalho sua contundente atuação político-social.

$\mathrm{O}$ encenador russo que desenvolveu sua arte no início do século XX - nasceu em 1874 e foi fuzilado em 1940 - norteou seu desenvolvimento artístico desde o início de carreira pela busca do diálogo entre arte/teatro e sociedade e aprofundamento na pesquisa acerca de forma/conteúdo visando uma nova relação palco/plateia. Como ator profisssional do Teatro de Arte de $\operatorname{Moscou}^{15}$, tais focos e sua insatisfação em relação à linha desenvolvida pelo teatro fundado por K. Stanislávski e N. Dântchenko ficaram evidentes em carta enviada à sua primeira esposa, Olga Munt, datada de 22 de julho de 1898 :

[...] Chorei e tive vontade de fugir de lá. Só se fala aqui da forma. Beleza, beleza, beleza! Não há lugar aqui para a ideia da peça e, quando eles falam sobre isso, é ultrajante. Meu Deus! Como essas pessoas bem alimentadas, esses capitalistas reunidos no Templo de Melpómene para o seu próprio prazer, para isso e nada mais, realmente podem entender a ideia por trás de Hannele, de Hauptmann? Talvez possam, mas eles não o querem, nunca, infelizmente. ${ }^{16}$

Na função de ator, Meyerhold sentiu necessidade de ser mais participativo e atuante em tudo o que circundava a peça que estava sendo montada, e carecendo de uma análise mais ampla que incluísse as implicações sociais dos temas tratados. Necessidade essa expressa em trecho da carta endereçada a Nemiróvitch-Dântchenko (datada de 17 de janeiro de 1899) na qual questionou a abrangência do papel do ator:

[...] Realmente somos o elenco que supostamente deve atuar e nada mais? Queremos também pensar enquanto atuamos. Queremos saber por que estamos atuando, o que estamos atuando e a quem estamos ensinando ou criticando com nossa atuação. Para fazer o que queremos, precisamos saber; nós queremos e precisamos ter clareza sobre a significação social e

\footnotetext{
${ }^{15}$ Ingressou no TAM no momento de sua fundação, em 1898.

${ }^{16}$ TAKEDA, Cristiane Layher. O cotidiano de uma lenda: cartas do Teatro de Arte de Moscou. São Paulo: Perspectiva: FAPESP, 2003, p. 71.
} 
psicológica da peça, as personagens positivas e negativas, qual sociedade ou com quais membros o autor simpatiza ou não. Só então, resumindo, os atores estarão conscientemente aptos para expressar as ideias do autor e só então o público conscientemente poderá se relacionar com a peça. ${ }^{17}$

Essas vivências, sua sede por outra forma de relação com o espectador e a necessidade de radicalização na comunicação foram o cerne de sua busca por um novo paradigma teatral, e levaram-no a desligar-se do TAM em 1902. Leach comenta ${ }^{18}$ :

A causa/fator fundamental da ruptura entre Stanislávski e Meyerhold logo no início do século deve-se à divergência de ponto de vista acerca do lugar ocupado pelo espectador ${ }^{19}$ no evento teatral. Stanislávski ensinava que: "um ator deve ter um ponto de atenção, e esse ponto de atenção não pode estar no público' e que 'durante a apresentação [...] é importante que a sequência dos objetos nos quais (o ator) se foca forme uma linha sólida. Essa linha deve manter-se do seu lado da ribalta, e não vaguear nenhuma vez pela plateia". Meyerhold sempre se opôs a esse conceito de o ator deliberada e indiscriminadamente excluir o espectador de sua consciência, e desde 1907 postulava um ator que 'se coloca frente a frente com o espectador [...] e livremente revela sua alma a ele intensificando assim a relação teatral fundamental entre ator e espectador'. ${ }^{20} 21$

O teatro de Meyerhold sempre foi voltado para o espectador, para quem está vendo - inclusive os demais atores (informação verbal) ${ }^{22}$. Vejamos:

Para Meyerhold o espectador era a quarta dimensão vital sem a qual não haveria teatro. As outras três dimensões - o dramaturgo, o diretor e o ator trabalhariam em vão se não houvesse o espectador, uma vez que é em algum lugar entre eles e seus espectadores que o teatro 'acontece'. ${ }^{23} 24$

\footnotetext{
${ }^{17}$ TAKEDA, Cristiane Layher. O cotidiano de uma lenda: cartas do Teatro de Arte de Moscou. São Paulo: Perspectiva: FAPESP, 2003, p. 98.

${ }^{18}$ Os textos citados provenientes de originais em inglês e espanhol são tradução nossa e a versão na língua original será sempre incluída em nota de rodapé, após indicação da referência bibliográfica.

${ }^{19}$ Optou-se por traduzir a palavra audience(s) por espectador.

${ }^{20}$ LEACH, Robert. Vsévolod Meyerhold. Cambridge: University Press, 1993, p. 30.

${ }^{21}$ The fundamental cause for the split between Stanislavsky and Meyerhold at the very beginning of the century lay in they divergent views of the place of the audience in the theatrical event. Stanislavsky taught that: 'an actor must have a point of attention, and this point of attention must not be in the auditorium' and that 'during a performance ... it is important that the sequence of objects you focus on should form a solid line. That line must remain on your side of the footlights, and not stray once into the auditorium'. Meyerhold always opposed this conception of the actor deliberately and unwaveringly excluding the spectator from his consciousness, and as early as 1907 posited an actor who 'stands face to face with the spectator... and freely reveals his soul to him, thus intensifying the fundamental theatrical relationship of performer and spectator'.

${ }^{22}$ Anotações feitas durante aula da disciplina "V. Meyerhold e o ator do futuro: processos de incorporação vistos pelas neurociências" ministrada pela Prof". Dra. Yedda Chaves de Carvalho no programa de pós-graduação da ECA/USP no dia 18 de março de 2010.

${ }^{23}$ LEACH, op. cit., p.30.

${ }^{24}$ For Meyerhold, the audience was the vital fourth dimension without which there was no theatre. The other three 'dimensions' - the playwright, the director, and the actor - worked to no avail if they had no audience, for it was somewhere between them and their audience that theatre 'happened'.
} 
Essa preocupação o levará a propor uma nova forma de relação palco/plateia que chamou de teatro de linha reta, em oposição ao "[...] teatro triângulo - cujo ápice representa o encenador, e os dois ângulos da base o autor e o ator. $\mathrm{O}$ espectador percebe a arte dos dois últimos através da arte do encenador (neste esquema o lugar do espectador encontra-se acima do ápice do triângulo)" (Meyerhold apud MARIA THAIS) ${ }^{25}$. A autora afirma que, para Meyerhold, o teatro triângulo

[...] privava o ator de sua liberdade criativa. O diretor estava no ápice de um triângulo imaginário, nos dois cantos restantes foram colocados o ator e autor, respectivamente. Seus trabalhos, em seguida, fluíam pelos dois lados do triângulo em direção ao diretor. Enquanto isso, o espectador estava, por assim dizer, além do diretor, e era através da sensibilidade do diretor que ele ou ela era capaz de ver e entender o trabalho dos outros dois artistas. [...] Meyerhold passou a argumentar apaixonadamente que "a arte do ator consiste em muito mais do que apenas familiarizar o espectador com a concepção do diretor". ${ }^{26} 27$

A proposta do teatro de linha reta prevê que "[...] o encenador, tendo assimilado o autor, traz ao ator sua própria arte [...]. O ator, tendo abordado a obra do autor por intermédio do encenador, vai encontrar-se face a face com o espectador [...] e revela sua alma livremente perante o público, acentuando assim a ação recíproca dos dois elementos fundamentais do teatro: ator e espectador."

Teatro de linha reta: uma linha reta (horizontal), onde os quatro fundamentos do teatro são representados por quatro pontos da esquerda para a direita: autor, encenador, ator e espectador. ${ }^{28}$

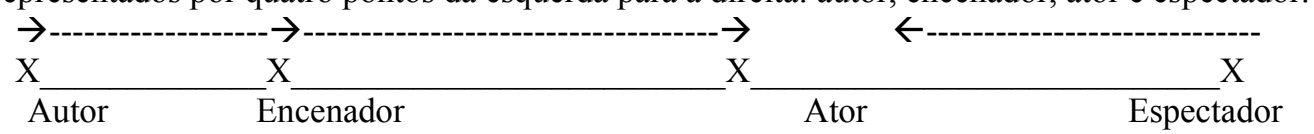

Desde seus primeiros trabalhos Meyerhold desafiou as convenções do teatro naturalista e focou sua atenção na criatividade dos espectadores, questionando a necessidade de grandes aparatos que visavam o convencimento do espectador. Bennett descreve:

\footnotetext{
${ }^{25}$ MARIA THAIS. Na cena do Dr. Dapertutto: poética e pedagogia em V. E. Meierhold: 1911 a 1916. São Paulo: Perspectiva/FAPESP, 2009, p. 220.

${ }^{26}$ LEACH, Robert. Stanislavsky and Meyerhold. Bern: Peter Lang, 2003, p. 34.

${ }^{27}$ This is what Meyerhold called the 'Theatre-Triangle', and it inevitably, according to Meyerhold, deprived the actor of his creative freedom. The director stood at the apex of an imaginary triangle, at the two remaining corners of which were placed the actor and the author respectively. Their work then flowed down the two sides of the triangle towards the director. Meanwhile, the spectator stood, as it were, beyond the director, and it was through the director's sensibility that he or she was able to see and understand the work of the other two artists. [...] Meyerhold went on to argue passionately that 'the actor's art consists in far more than merely acquainting the spectator with the director's conception'.

${ }^{28}$ MARIA THAIS, op. cit., p. 222.
} 
Todas as armadilhas do teatro comercial foram evitadas em favor de montagens não ilusionistas e componentes cênicas politicamente relevantes (cartazes, folhetos, atores na plateia para guiar reações). A quebra da barreira tradicional do proscênio, como Edward Braun assinala, providenciou "uma vantagem adicional $[\ldots]$ que insinuava uma polêmica contra o teatro burguês de escapismo e ilusão". ${ }^{29} 30$

Embora como parte do jogo cênico, trata-se de uma busca por estabelecer uma relação diferente daquela vigente, ou uma nova teatralidade, a qual foi posteriormente ampliada para pesquisa do Teatro da Convenção ${ }^{31}$ :

Meyerhold $^{32}$ recorreu à história do teatro para construir suas ideias de renovação da cena. Do drama antigo a Molière, do teatro de feira a Wagner, da Commedia dell'Arte a Púschkin, o encenador recuperou aspectos das antigas tradições cênicas e literárias a fim de defender novos procedimentos para o ator. No novo teatro, o teatro de Convenção, de jogo, o problema da técnica do ator tornou-se protagonista e colaborou para a formulação e a experimentação de um conceito de teatralidade, que se desenvolveu ao longo de sua trajetória como encenador. ${ }^{33}$

Esse novo conceito de teatralidade que ele buscava, aliado à tentativa de dissociação com o realismo, deve ser compreendido na amplitude de sua proposta:

Quando Meyerhold fala de realismo, ele distingue entre o realismo que imita as situações do cotidiano e o realismo que aporta novas visões ao mesmo. $\mathrm{O}$ primeiro não modifica a vida, ao máximo a documenta como faz a fotografia jornalística; o segundo, aspirado por Meyerhold, através de técnicas de composição enriquece as reservas de conhecimento por via da percepção e apercepção. $^{34}$

O caráter político do teatro de Meyerhold ficou evidenciado por suas escolhas e focos que instauraram uma nova forma de relação social no teatro a partir da quebra da quarta parede e ruptura com o realismo.

O movimento foi o cerne de sua poética, considerando que era a partir dele que seria suscitada a emoção. Chaves salienta que o encenador

\footnotetext{
${ }^{29}$ BENNETT, Susan. Theater audiences: a theory of production and reception. London: Routledge, 1990, p. 6.

${ }^{30}$ All the trappings of commercial theater were eschewed in favour of non-illusionistic staging and politically relevant scenic components (placards, leaflets, actors in the audience to guide reactions). The breaking of the traditional barrier of the proscenium provided, as Edward Braun points out, "an additional advantage... that this implied a polemic against the bourgeois theater of escapism and illusion".

${ }^{31}$ Conforme citação de Yedda Carvalho Chaves, "para Meyerhold o 'Novo Teatro' ou 'Teatro da Convenção' está vinculado à recusa do excesso da cena realista/naturalista, a qual havia sobrecarregado o palco com clichê antiartístico" (CHAVES, Yedda Carvalho. A Biomecânica como princípio constitutivo da arte do ator. Dissertação de mestrado. ECA/USP, 2001, p. 11)

${ }^{32}$ Para manter padronização na escrita do nome de Meyerhold neste trabalho, mesmo quando o autor citado utilize a grafia Meierhold, será utilizada versão com ' $y$ '.

${ }^{33}$ MARIA THAIS, Na cena do Dr. Dapertutto: poética e pedagogia em V. E. Meierhold: 1911 a 1916. São Paulo: Perspectiva/FAPESP, 2009, p. 57.

${ }^{34}$ CHAVES, op. cit., p. 34.
} 
concebe o movimento não como resultado ou objetivo do comportamento, mas como fase principal da realização cênica do pensamento, como um degrau que é possível ser saltado. Somente no movimento - e com o movimento - pode nascer no ator uma emoção precisa e uma palavra motivada interiormente. ${ }^{35}$

Propõe uma re-teatralização, baseada principalmente em três matrizes das revoluções de 1905 e $1917^{36}$ : a música, a dança e formas de estilização do corpo, a partir do que passa a ser imprescindível sentir as formas e não somente as emoções da alma, dar uma espécie de tratamento gráfico ao sentimento, construir a cena não mais como tentativa de imitação servil da realidade, mas buscando estilizá-la (informação verbal) ${ }^{37}$.

A opção pela utilização do grotesco, recorrente em seu trabalho, aparece na via da estilização. Por grotesco podemos compreender que

é uma estrutura. Poderíamos designar a sua natureza com uma expressão, que já se nos insinuou com bastante frequência: o grotesco é o mundo alheado (tornado estranho). Mas isto ainda exige uma explicação. O mundo dos contos de fadas, quando visto de fora, poderia ser caracterizado como estranho e exótico. Mas não é um mundo alheado. Para pertencer a ele, é preciso que aquilo que nos era conhecido e familiar se revele, estranho e sinistro. Foi pois o nosso mundo que se transformou. O repentino e a surpresa são partes essenciais do grotesco. ${ }^{38} 39$

\footnotetext{
${ }^{35}$ CHAVES, Yedda Carvalho. A Biomecânica como princípio constitutivo da arte do ator. Dissertação de mestrado. ECA/USP, 2001, p. 70.

${ }^{36}$ A Revolução Russa de 1905 foi a primeira grande revolução popular da época imperialista, a primeira revolução em que a classe operária interveio como força autônoma - com reivindicações e formas de luta próprias, fatos que, só por si, a tornaram um acontecimento de significado mundial. Para Lênin, ainda que tenham sido os acontecimentos de Outubro (greve geral que paralisou praticamente toda a Rússia, mobilizando mais de 2 milhões de trabalhadores), a revolução começou no dia 22 de Janeiro de 1905, com o "Domingo Sangrento", nome pelo qual ficou conhecido o massacre de operários perpetrado pelas tropas czaristas, quando milhares de operários se dirigiam pacificamente para o Palácio de Inverno para implorar junto do Czar uma vida melhor e mais liberdade. No conjunto das reivindicações destacam-se: anistia, liberdades cívicas, salário razoável, entrega progressiva da terra ao povo, convocação de uma Assembleia Constituinte por sufrágio universal.

A Revolução Russa de 1917 foi resultante de uma série de eventos políticos que, após a eliminação da autocracia, e depois do Governo Provisório (Tataks), estabeleceu o poder soviético sob o controle do partido bolchevique. Compreendeu duas fases distintas: a Revolução de Fevereiro (março de 1917, pelo calendário ocidental - ou gregoriano), que derrubou a autocracia de Nicolau II, o último Czar a governar, e procurou estabelecer em seu lugar uma república de cunho liberal; a Revolução de Outubro, na qual o Partido Bolchevique, liderado por Lênin, derrubou o governo provisório e impôs o governo socialista soviético. A Revolução Bolchevique ocorreu, no calendário juliano (ou oriental), em 25 de outubro de 1917 e, no calendário gregoriano, no dia 07 de novembro. Foi primeira revolução socialista da história da humanidade, tendo como consequência geopolítica a criação, a partir de 1922, da União das Repúblicas Socialistas Soviéticas (URSS).

${ }^{37}$ Anotações feitas durante aula da disciplina "V. Meyerhold e o ator do futuro: processos de incorporação vistos pelas neurociências" ministrada pela Prof". Dra. Yedda Chaves de Carvalho no programa de pós-graduação da ECA/USP no dia 18 de março de 2010.

${ }^{38}$ Esta afirmação é uma das três acepções de grotesco apresentadas por Wolfgang Kayser no livro mencionado abaixo.

${ }^{39}$ KAYSER, Wolfgang. O grotesco: configuração na pintura e na literatura. São Paulo: Perspectiva, 1986, p. 159.
} 
Para Meyerhold o grotesco não se resume a "estilo", ele o considera um método: “Grotesco: Exageração e transformação intencional (alteração) de dados naturais. Além de associar objetos que a própria natureza ou a nossa experiência cotidiana habitualmente não conciliam, coloca em relevo as características de uma acentuada deformação" (Meyerhold apud BONFITTO $)^{40}$. Sua opção pelo grotesco deveu-se principalmente ao fato de que "[...] o que é essencial no grotesco é o modo constante com o qual ele desloca o espectador de um plano perceptivo que acabou de intuir, para um outro que ele não esperava" (Picon-Vallin apud BONFITTO). ${ }^{41} 42$

Meyerhold estava atento aos novos caminhos apontados pela arte e pela ciência naquele momento e passou a priorizar modelos que se tornaram dominantes,

como as vanguardas produtivas e construtivas: atores operários, teatro nas fábricas, taylorização na interpretação; modelos, estes, que estão ligados à radicalização das suas posições políticas, ao seu empenho na revolução, ao seu interesse crescente pela máquina e pela fábrica. ${ }^{43}$

Debruçou-se no estudo sobre neurofisiologia, psicologia experimental e reflexologia ${ }^{44}$ (relação corpo e cérebro) baseando-se, entre outras, na Teoria das emoções periféricas proposta por William James - que afirmava que as emoções surgem a partir da ação, da movimentação - a fim de fazer com que a experiência teatral fosse parte constitutiva do período revolucionário que vivia (informação verbal) ${ }^{45}{ }^{46}$

Sua proposição acerca da ação psicofísica indica tal embasamento uma vez que, segundo afirmação de Bonfitto, “[...] privilegia o percurso que parte da execução para o

\footnotetext{
${ }^{40}$ BONFITTO, Matteo. O ator-compositor: as ações físicas como eixo - de Stanislávski a Barba. São Paulo: Perspectiva, 2002, p. 42.

${ }^{41}$ Ibidem, p. 43.

${ }^{42}$ Buscando elucidar o conceito à luz de uma das tradições teatrais que mais influenciaram Meyerhold, a commedia dell'arte, Kayser ilustra dizendo que "é grotesco quando as personagens da commedia dell'arte e de toda arte dela derivada se convertem em bonecos articulados, movidos de forma mecânica; quando no organicamente animado penetra o mecanicamente inanimado tornando com isso estranho o nosso mundo." KAYSER, Wolfgang. O grotesco: configuração na pintura e na literatura. São Paulo: Perspectiva, 1986, p. 50 .

${ }^{43}$ CHAVES, Yedda Carvalho. A Biomecânica como princípio constitutivo da arte do ator. Dissertação de mestrado. ECA/USP, 2001. p. 17.

44 "A nova teoria da reflexologia - inter-relação dos reflexos condicionados e não - levou-nos a estudar o comportamento do ator em cena também deste ponto de vista. [...] No entanto, nós não treinamos somente a fisiologia, mas também o cérebro, e não se trata de um simples treinamento, mas de uma visão dialética do treinamento." (Meyerhold apud CHAVES, op. cit., p. 71)

${ }^{45}$ Anotações feitas durante aulas da disciplina "V. Meyerhold e o ator do futuro: processos de incorporação vistos pelas neurociências" ministrada pela Profa. Dra. Yedda Chaves de Carvalho no programa de pósgraduação da ECA/USP nos dias 18 e 25 de março, 20 e 27 de maio de 2010.

${ }_{46}$ JAMES, William. What's an emotion. [?]
} 
desencadeamento dos processos interiores" ${ }^{47}$, elucidando cunho social e histórico da ação psicofísica.

As inovações propostas por Meyerhold fizeram eco no desenvolvimento do teatro no século XX como um todo, podendo ser identificadas e relacionadas em diversos aspectos à obra de Bertolt Brecht, conforme nos apresenta Eaton:

Meyerhold era conhecido pelo público de São Petersburgo como 'o homem das novas ideias'. Algumas dessas ideias anteciparam a teoria e prática de Brecht. As mais notáveis são as inovações estilísticas usadas para destruir a convenção do palco realista, tais como projeção de filmes, cartazes com comentários ou anunciando a ação, intercalação de danças e músicas (songs), [...] e o treinamento de atores artística e socialmente conscientes. [...] Brecht e Meyerhold foram condicionados pelo mesmo milieu revolucionário, acreditavam numa arte não ilusionista que serve a humanidade, e foram atraídos por elementos semelhantes dos teatros tradicionais do Oriente e Ocidente. ${ }^{4849}$

Em seu livro A linguagem da encenação teatral, Roubine salienta a influência exercida por Meyerhold sobre este e outros expoentes do teatro político, social:

E não é por acaso que homens de teatro como Piscator e Brecht, preocupados com a criação de formas novas adaptadas a um novo conteúdo e com a invenção de uma realização cênica crítica e política, atribuíram enorme importância às pesquisas de Meyerhold. Toda a sua obra demonstrou, com efeito, que, ao colocar em oposição o sentido e a forma, o teatro de texto e o teatro sem texto, deturpava-se e simplificava-se a crucial questão das relações entre texto e espetáculo. ${ }^{50}$

O "ator do futuro" - segundo nomeação dada por Meyerhold - estava no centro de suas aspirações, e para alcançá-lo era necessário ampliar a conscientização do ator em relação à sua função. Em palestra proferida no dia 12 de junho de 1922, Meyerhold afirma:

A arte do ator consiste em organizar seu material: isto é, na sua capacidade de utilizar corretamente os meios de expressão de seu corpo. $\mathrm{O}$ ator traz em si mesmo ambos o organizador e aquilo que é organizado (ou seja, o artista e seu material). A fórmula para a atuação pode ser expressa da seguinte maneira: $\mathrm{N}=\mathrm{A} 1+\mathrm{A} 2$ (onde $\mathrm{N}=\mathrm{o}$ ator, $\mathrm{A} 1=\mathrm{o}$ ator que concebe a ideia $\mathrm{e}$ cria as instruções necessárias para sua execução; $\mathrm{A} 2=\mathrm{o}$ executante que executa a concepção de A1). [...] Todos os estados psicológicos são determinados por específicos processos fisiológicos. Resolvendo

\footnotetext{
${ }^{47}$ BONFFITTO, op. cit., p. 39.

${ }^{48}$ EATON, Katherine Bliss. The theater of Meyerhold and Brecht. Westport: Greenwood Press, 1986, p. 9.

${ }^{49}$ Meyerhold was known to St Petersburg audiences as 'the man with the new ideas'. Some of these ideas closely anticipated the theory and practice of Brecht. Most notable are those stylistic innovations used to destroy the realistic stage convention, such as film projections, posters with comment on or announce the action, interpolation of dances and songs, [...] and the training of actors as artistically and socially conscious performers. [...] Brecht and Meyerhold were conditioned by the same revolutionary milieu, believed in a nonillusionistic art which serves humanity, and were attracted to similar elements in the traditional theaters of the Orient and the West.

${ }^{50}$ ROUBINE, Jean-Jacques. A linguagem da encenação teatral. Rio de Janeiro: Jorge Zahar, 1998, p. 62.
} 
corretamente a natureza de seu estado fisicamente, o ator alcança o ponto em que ele experiencia a excitação que se comunica com o espectador e o induz a compartilhar a performance do ator: o que costumávamos chamar de "cativar" o espectador. (Meyerhold apud BRAUN) ${ }^{5152}$

Yedda Carvalho Chaves, em sua tese de doutoramento intitulada V. Meyerhold: um percurso através do processo de incorporação - Traços de uma herança traz a tradução de material de Meyerhold - direto do russo - em que ele afirma que "o ator é mais livre na sua criação, pois, enquanto ele cria sob os olhos do espectador, sua arte é processo e resultado ao mesmo tempo". E segue afirmando que o ator tem que estar disposto a correr "riscos expressivos", que dizem respeito à ruptura dos limites perceptivos e ao desenvolvimento de novas integrações entre cérebro, corpo e mente (informação pessoal). ${ }^{53}$

Assim sendo, torna-se evidente o fato de que

[...] como qualquer artista genuíno, talvez particularmente aquele que alega ser marxista em sua abordagem, Meyerhold não estava meramente interessado na obra de arte como um objeto em si, ele estava igualmente interessado em seus "meios de produção", que em termos de teatro inclui a colaboração dos "consumidores" ou espectadores. "Pretendemos que o público não apenas observe", escreveu ele em 1907, "mas participe conjuntamente num ato criativo". 5455

As ideias teatrais mais importantes de Meyerhold buscavam ampliar e dinamizar o papel do teatro. Entre elas destacam-se:

[...] a transformação do palco tradicional em teatro agitprop, do ator "acadêmico" em organizador das massas socialmente ativo (grifo nosso), transformação da plateia como "encontro para trocas/intercâmbios" em um "coletivo fortemente estabelecido que interaja com a peça", a transferência da atenção dos aspectos puramente narrativos da peça para os métodos de sua construção [e] a invenção dos melhores métodos de organização (que transforme) um grupo em um coletivo cooperador". 5657

\footnotetext{
${ }^{51}$ BRAUN, Edward. Meyerhold: a revolution in theater. London: The Bath Press, 1995, p. 172-173.

${ }^{52}$ The art of the actor consists in organizing his material: that is, in his capacity to utilize correctly his body's means of expression. The actor embodies in himself both the organizer and that which is organized (i.e. the artist and his material). The formula for acting may be expressed as follows: $N=A 1+A 2$ (where $N=$ the actor; $A 1=$ the actor who conceives the idea and issues the instructions necessary for its execution; $A 2=$ the executant who executes the conception of A1). (...) All the psychological states are determined by specific physiological processes. By correctly resolving the nature of his state physically, the actor reaches the point where he experiences the excitation that communicates itself to the spectator and induces him to share in the actor's performance: what we used to call 'gripping' the spectator'.

${ }^{53}$ CHAVES, Yedda Carvalho. V. Meyerhold: um percurso através do processo de incorporação - Traços de uma herança. Tese de doutoramento (a tese de doutoramento encontra-se em fase de preparação para publicação). Mensagem recebida por camila_scudeler@yahoo.com.br em 27 set. 2010.

${ }_{54}^{54}$ LEACH, Robert. Vsévolod Meyerhold. Cambridge: University Press, 1993, p. 45.

${ }^{55}[\ldots]$ ]like any genuine artist, perhaps particularly one claiming to be Marxist in his approach, Meyerhold was interested not merely in the work of art as an object in itself, he was equally interested in its "means of production", which in terms of theatre includes the collaboration of the "consumers" or audience. "We intend the audience not merely to observe", he wrote in 1907, "but to participate in a corporate creative act".

${ }^{56}$ EATON, Katherine Bliss. The theater of Meyerhold and Brecht. Westport: Greenwood Press, 1986, p. 24.
} 
Em carta enviada a Tchekhov em 18 de abril de 1901, Meyerhold expressou sua indignação com o status quo e creditou ao teatro um lugar de destaque no processo revolucionário:

[...] Eu me revolto abertamente contra a arbitrariedade policial, da qual fui testemunha em Petersburgo no dia 04 de março, e não consigo me dedicar com seriedade à minha arte quando meu sangue ferve e tudo me chama à luta. Desejo arder com o espírito do meu tempo. Desejo que todos os homens de teatro tomem consciência da alta missão deles. Não posso apreciar tranquilamente meus companheiros que, alheios ao interesse público, se negam a se colocar acima dos interesses de classe. Sim, o teatro pode desempenhar um papel imenso na transformação de tudo o que existe! ${ }^{58}$

Embora não tenha isoladamente a possibilidade de transformar o mundo ou se responsabilizar por revoluções, Eagleton em Marxismo e crítica literária corrobora com tal afirmação salientando que: “[...] a teoria materialista da história nega que a arte possa por si só mudar o curso da história, mas insiste que ela pode constituir um elemento ativo dessa mudança". 59

Seu "grito", seu "chamado" a se pensar o teatro também a partir de sua função social levou Meyerhold a explorar e incentivar uma nova atitude atoral: o ator passou a desencadear os processos de atuação não somente a partir dos conteúdos oferecidos por um texto dramático, mas a partir de matriz psicofísica social, ampliando suas possibilidades expressivas e de diálogo com o texto.

A biomecânica surgiu, de alguma forma, como concretização de inúmeros experimentos feitos ao longo de muitos anos. Sua "invenção", no entanto, data de 1918, um ano após a Revolução. O nome foi sugerido por um médico amigo de Meyerhold, e esse treinamento psicofísico para o ator é resultado do cruzamento de tradições do teatro, os estudos de Vladimir Bekhterev, William James, da psicologia, do taylorismo ${ }^{60}$, da ideologia...

\footnotetext{
${ }^{57}$ The transformation of the traditional stage into agitprop theater, of the "academic" actor into a socially active organizer of the masses, of the audience from a "change gathering" into a "firmly established collective which interacts with the play", the transfer of attention from the purely narrative aspects from the play to the methods of its construction, [ and ] the invention of the best methods for the organization of a group into a cooperating collective.

${ }^{58}$ TAKEDA, Cristiane Layher. O cotidiano de uma lenda: cartas do teatro de Arte de Moscou. São Paulo: Perspectiva: FAPESP, 2003, p. 178.

${ }^{59}$ EAGLETON, Terry. Marxismo e crítica literária. Porto: Edições Afrontamento, 1976, p. 22.

${ }^{60}$ Conjunto de estudos desenvolvidos por Frederick Taylor (1856-1915) e aplicados nas indústrias de todo o mundo, determinando a organização do processo de trabalho contemporâneo. Tem por finalidade racionalizar a produção, logo, de possibilitar o aumento da produtividade do trabalho, "economizando tempo", suprimindo gestos desnecessários e comportamentos supérfluos no interior do processo produtivo. RAGO, Luzia Margareth; MOREIRA, Eduardo F. P. O que é taylorismo. São Paulo: Brasiliense, 1984, p. 10 e 14.
} 
Em seu estúdio havia pessoas de diferentes áreas/origens: atores, bailarinos, pesquisadores e, inclusive um especialista em commedia dell'arte - cujos conhecimentos e materiais foram de suma importância para os estudos de Meyerhold. Segundo Chaves, alguns dos princípios básicos da biomecânica:

- A biomecânica é fundada sobre o princípio de que movendo-se a ponta do nariz, o corpo todo se move. O corpo todo é envolvido pelo movimento do menor órgão. Ocorre, antes de tudo, encontrar a estabilidade do corpo inteiro. À menor tensão, todo o corpo reage.

- Na biomecânica, cada movimento é composto por três momentos: a) intenção; b) equilíbrio; c) execução.

- Os requisitos básicos da biomecânica são a coordenação no espaço e em cena, a capacidade de encontrar o próprio centro do grupo em movimento, a capacidade de adaptação, de cálculo e de precisão no olhar.

- A biomecânica não tolera nada de casual, tudo deve ser feito com consciência a partir do estoque de cálculos feitos em precedência. Todos que participam do trabalho devem estabelecer com precisão e ser conscientes da posição em que se encontra o próprio corpo, e também usar com desenvoltura cada parte do corpo para colocar em prática o seu propósito. ${ }^{61}$

Ao descrever em sua dissertação de mestrado sua vivência de treinamento da biomecânica ministrado pelo diretor e ator russo Guenádi Bogdanov, Chaves lembra que "é [...] com o objetivo de romper com o 'piloto automático' que os primeiros exercícios são propostos. O princípio de que 'nada é casual' e de que a cada momento o ator deve ter 'consiência das relações que está estabelecendo' encontra-se na base de todo treinamento.,"62 E completa afirmando que “[...] a biomecânica é um aprendizado do corpo, mas não no sentido de um corpo virtuoso, e sim de um corpo que pensa."

O treinamento de biomecânica no Teatro de Meyerhold era estruturado, via de regra, em três etapas que iam da realização de exercícios, passando pelo trabalho com os études ${ }^{64}$, até improvisação com tema. ${ }^{65} \mathrm{Um}$ dos pilares do treinamento psicofísico da

\footnotetext{
Grigolo, no entanto, nos apresenta a seguinte ressalva: "A zona de contato entre o sistema taylorista e as proposições de Meyerhold não estaria na radicalização dos processos produtivos, na construção de um 'atorpadrão, mas na possibilidade de articulação interna (da cena) com os mecanismos operantes no espetáculo, como também na divisão do trabalho em concepção e execução." GRIGOLO, Gláucia. O ator do futuro: por Meyerhold. Artigo disponível no site: ttp://www.portocenico.com.br/artigos/O_ator_do_futuro_por_meyerhold.

${ }^{61}$ CHAVES, Yedda Carvalho. A Biomecânica como princípio constitutivo da arte do ator. Dissertação de mestrado. ECA/USP, 2001, p. 49.

${ }^{62}$ Ibidem, p. 119.

${ }^{63}$ Ibidem, p. 117.

${ }^{64}$ Assim como a maioria dos estudiosos da área, optamos por manter o a palavra em francês por este estar ancorado ao termo técnico-musical, sem correr o risco de confundi-la com estudo.
} 
biomecânica, esta "composição cênica extraída de várias convenções teatrais"66 são verdadeiros amálgamas de princípios expressivos de diferentes fontes e servem ao ator como amplas fontes de estímulos. ${ }^{67}$ Leach salienta que "cada étude foi concebido como tendo uma forma arquetípica em que o ator poderia expressar-se: como a forma do soneto serve para o poeta, assim também o étude biomecânico deveria fornecer uma disciplina externa para o ator, dentro da qual ele tinha liberdade interna de desempenho." 6869 Segundo Bogdanov

cada étude contém uma série de problemas sobre os quais o ator deve trabalhar. [...] Um modelo completo e que contém tudo aquilo que constitui um espetáculo na sua totalidade e complexidade: um início, um desenvolvimento e um fim, com as suas características rítmicas e dramáticoexpressivas. (Bogdanov apud CHAVES) ${ }^{70}$

Dentre as ciências que despertavam o interesse de Meyerhold, a psicologia ${ }^{71}$ teve papel fundamental, pois havia pesquisadores extremamente agudos na URSS que trabalhavam com a relação de como os movimentos ocorrem no cérebro. A divisão do movimento do ator em cena em três partes está intimamente relacionada à descoberta feita por Ivan Pavlov acerca dos reflexos condicionados. Pavlov distinguiu no movimento três momentos: a intenção, o movimento e a reação; a partir disso Meyerhold dividiu o movimento cênico em:
1. INTENÇÃO
2. REALIZAÇÃO
3. REAÇÃO
A Intenção é a assimilação intelectual de uma tarefa prescrita externamente pelo dramaturgo, o diretor ou por iniciativa do ator. A Realização é o ciclo volitivo, mimético e os reflexos vocais. A Reação é a atenuação do reflexo volitivo após sua realização mimética e vocalmente, preparatória para a recepção de uma nova

\footnotetext{
65 “A aula básica consistia em exercícios físicos, seguido por dois études. [...] Os exercícios progrediam de correr, pular, rolamentos, e assim por diante, para acrobacias bastante avançadas, e eram tipicamente biomecânicos em sentido estrito - varrendo, forte, através de movimentos amplos planos diferentes, muitas vezes baseada em joelhos, flexão. [...] Mas este não era o caso com os études. Se os exercícios (físicos) eram concebidos para promover o controle técnico, os études seguiam numa dimensão teatral. In: LEACH, Robert. Stanislavsky and Meyerhold. Bern: Peter Lang, 2003, p. 111.

The class consisted of basic physical exercises, followed by two etudes. [...] The exercises progressed from running, leaping, rolls, and so on, to quite advanced acrobatics, and were typically Biomechanical in the narrow sense - sweeping, strong, broad movements through different planes, often based in knees, flexing. [...] But this was not the case with the études. If the exercises were designed to foster technical control, the etudes moved into a theatrical dimension.

${ }^{66}$ CHAVES, Yedda Carvalho. A Biomecânica como princípio constitutivo da arte do ator. Dissertação de mestrado. ECA/USP, 2001, p. 112 - nota 132.

${ }^{67}$ Dos cerca de 50 études que eram ensinados no Teatro de Meyerhold, apenas 8 são conhecidos e praticados atualmente - resultado dos longos anos a que toda a obra de Meyerhold foi condenada ao ostracismo após seu fuzilamento, em 1940.

${ }^{68}$ LEACH, Robert. Stanislavsky and Meyerhold. Bern: Peter Lang, 2003, p. 152.

${ }^{69}$ Each étude was conceived as having an archetypal form within which the actor could express himself: as the sonnet form does for the poet, so the Biomechanical etude was to provide an external discipline for the actor, within which he had internal freedom of performance.

${ }^{70}$ CHAVES, op. cit., p. 142-143.

${ }^{71}$ Os psicólogos da época trabalhavam a questão do movimento em nível cerebral - esses cientistas são os precursores da neurociência de hoje.
} 
intenção ( a transição para um novo ciclo de atuação). (Garin apud BRAUN) ${ }^{72} 73$

Depois que o ator tinha se apropriado e internalizado os princípios do movimento, podia seguir para a livre improvisação. Inicialmente isso era feito com base nos études, o ator podia então jogar com as características de cada um deles, variando ritmo e dinâmicas do movimento, jogando com seu parceiro, o espaço e objetos. O trabalho com a voz era adicionado ao trabalho com música e máscaras. "[...] Os études constituem o material com o qual o ator treina. Através de seus estudos com eles, ele deverá desenvolver a liberdade de agir/atuar/criar os mais variados papéis e estilos criativamente." 74

A biomecânica em, digamos, "estado bruto" foi levada à cena somente no espetáculo O Corno Magnífico, de 1922. Sofreu crítica ferrenha da 'crítica comunista' devido aos mais distintos aspectos: a forma como redimensionalizava o corpo, a encenação em si, a relação com o público, a utilização das máquinas, a relação com o texto - tratava-se de proposta radical e, considerada inaceitável.

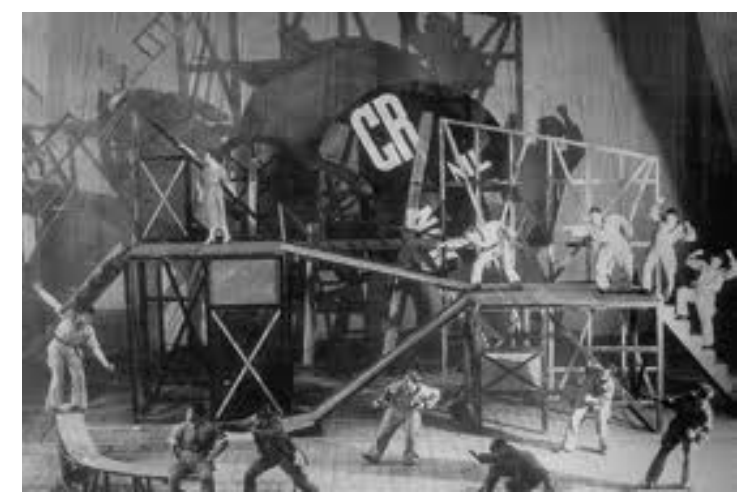

Cena do espetáculo O Corno Magnífico, de Crommelinck.

Quando em temporada pela França o espetáculo foi censurado pelo governo local por outro motivo: foi considerado um espetáculo "comunista".

\footnotetext{
${ }^{72}$ BRAUN, Edward. Meyerhold: a revolution in theater. London: The Bath Press, 1995, p. 174.
73 1. INTENTION
2. REALISATION
3. REACTION

The Intention is the intellectual assimilation of a task prescribed externally by the dramatist, the director or the initiative of the performer.

The realization is the cycle of volitional, mimetic and vocal reflexes.

The reaction is the attenuation of the volitional reflex after its realization mimetically and vocally, preparatory to the reception of a new intention (the transition to a new acting cycle)

${ }^{74}$ Trecho extraído do vídeo: Meyerhold's Theatre and Biomechanics: A film by the Mime Center Berlin in collaboration with Gennadi Bogdanov / Item: Improvisation with mask and voice.
} 
Ao contrário do que muitas vezes é erroneamente interpretado, Bogdanov esclarece em que termos o treinamento é entendido na biomecânica: “[...] a coisa principal do sistema da biomecânica é o treinamento, que não é uma simples série de exercícios físicos, mas são exercícios que levam à compreensão das possibilidades do ator." (Bogdanov apud CHAVES) ${ }^{75}$

Definitivamente, aquelas novas proposições incomodaram, mobilizaram, subverteram o "lugar das coisas". O conjunto proposto por Meyerhold foi essencialmente subversivo, revolucionário.

Teatro como uma ferramenta importante numa mudança social foi um conceito que Meyerhold nunca abandonou. Sua opção pela busca da emancipação humana, e sua perspectiva por meio do teatro nortearam sua vida como um todo. Uma ideia que o impulsionou foi a convicção de que para mudar o teatro era preciso primeiro mudar o público, então a revolução buscou abrir a cena a um novo público: e essa era a condição para se mudar o teatro, e é sempre a condição para se mudar o teatro - mesmo hoje.

${ }^{75}$ CHAVES, Yedda Carvalho. A Biomecânica como princípio constitutivo da arte do ator. Dissertação de mestrado. ECA/USP, 2001, p. 120. 


\title{
3. PROCESSO DE MONTAGEM DO ESPETÁCULO Os filhos da Dita
}

\begin{abstract}
O tempo não é subjetivo, mas coletivo. Porque nós o dividimos como um pão. Um dia a Dita Chegou. Um dia a Dita ficou. Não se sabe do fundo de que intuição a certeza: "vai durar pouco", vã filosofia! Durou muito mais. Quanto? É a conta que queremos fazer. Queria que você soubesse. Queria que vocês soubessem não a vida como ela é. Ou foi. Não a história contada em seus detalhes. O assunto transborda: onde foi que enterramos o nosso passado? São filhos querendo saber dos pais, são pais querendo saber dos filhos. Da mesma pátria. Das vizinhas. Que dor tem que ser abafada para se cumprir o ciclo civilizador da razão. Quem está querendo enganar a quem, nesse jogo de menos tendo mais.
\end{abstract}

Texto do programa da peça Os filhos da Dita

Para acompanhar com acuidade os processos pessoais descritos neste trabalho fazse necessário um resumo dos caminhos percorridos coletivamente, ambos intrinsecamente ligados.

A escolha da ditadura civil militar brasileira de 1964 como tema de um espetáculo do Arlequins ocorreu em 2006 quando, há mais de um ano em cartaz com pra Não dizer que Não falei das Flores ${ }^{76}$ achamos por bem, paralelamente às apresentações, definir os rumos do próximo projeto do coletivo. E essa escolha se deu a partir de distintos estímulos. Um deles foi a leitura que Sérgio Santiago ${ }^{77}$ fez de uma edição especial da revista Caros Amigos ${ }^{78}$ sobre o tema e trouxe a ideia de fazer um espetáculo que visasse analisar aquele período com vistas ao nosso presente, focando no diálogo com as novas gerações. Outro foi resultante dos debates $^{79}$ que fazíamos após apresentação de pra Não dizer que Não falei das Flores. A peça, que tem como tema o sistema capitalista no Brasil nos dias atuais, adota como título o nome da célebre música de Geraldo Vandré ${ }^{80}$ para remeter a um momento da história do país em

\footnotetext{
${ }^{76}$ Espetáculo que marcou minha entrada no Arlequins. Após trabalhar com Ana Maria Quintal - atriz fundadora do grupo - na montagem de A mais-valia vai acabar, seu Edgar (direção Tim Urbinatti, com Pessoal da maisvalia, em 2005), fui convidada a integrar o Arlequins.

${ }^{77} \mathrm{Um}$ dos fundadores do grupo, é diretor e dramaturgo do Arlequins, e desenvolve trabalhos como ator e iluminador com os pseudônimos de Éjo de Rocha Miranda na dramaturgia, Sérgio Garcia na atuação e Ira Montenegro como iluminador.

${ }^{78} \mathrm{O}$ Golpe de 64: Edição dedicada à juventude que deseja conhecer em detalhes esse episódio da história política brasileira. Edição Especial 019 - Outubro 2004. Ed. Casa Amarela. (1 ${ }^{\text {a }}$ edição publicada nos 40 anos do Golpe civil-militar; uma $2^{\text {a }}$ edição foi publicada em outubro de 2008, em ocasião dos 40 anos do Ato Institucional $\mathrm{n}^{\mathrm{o}}$ 5)

79 "O debate, de certa forma, explicita a intenção do grupo e torna mais íntima a sua relação com o público e, consequentemente, com a comunidade. É um momento privilegiado durante o qual o grupo pode aferir o alcance de seu trabalho e também aprofundar o seu conhecimento sobre a realidade de seu público, tendo em vista a continuidade de sua militância artística.” In: GARCIA, Silvana. Teatro da militância - A intenção do popular no engajamento político. São Paulo: Editora Perspectiva, 2004, p. 187.

80 "Para não dizer que não falei das flores" (também conhecida como "Caminhando"), canção escrita e interpretada por Geraldo Vandré, ficou em segundo lugar no Festival Internacional da Canção de 1968 e, depois
} 
que, havendo um "inimigo comum", havia certa organização coletiva de diversos setores da sociedade, e busca esse título como força motivadora. No entanto, muitas pessoas eram atraídas ao teatro com a expectativa de assistirem a uma peça sobre a ditadura, e muitos dos jovens, estudantes, nos questionavam o porquê do título e demonstravam uma mescla de curiosidade e total desconhecimento sobre os anos de exceção de nosso país, desconhecimento esse resultado direto da própria ditadura e dos passos subsequentes a seu término, baseado em acordos que previam - e ainda hoje prevêem - um virar as páginas sem enfrentamento da verdade. Esta foi outra motivação que ficou nos cutucando: a necessidade de colocar o dedo nessa ferida, atualizar o assunto, colocá-lo como pauta do dia principalmente buscando analisar o quê daquele ontem que é presente no nosso hoje.

A partir dessas situações/inspirações, alguns membros do grupo identificaram-se com o tema mostrando grande interesse em pesquisar, aprofundar, analisar e criar a partir dele. Garcia comenta:

Em Brecht [...] não é mais a História que entra no teatro, mas o teatro que se insere na História. A realidade aparece, portanto, dimensionada historicamente, mas não uma História imutável, determinada por forças ocultas, mas uma relatividade histórica que, no "ser assim", traz implícito que "poderia ser de outra maneira". Logo, reproduzir essa atualidade histórica significa desvendá-la, descobrir o seu interior camuflado, da mesma forma que, no palco, revela-se a maquinaria teatral denunciando que "aquilo é teatro". A relação que se estabelece, assim, entre palco e plateia não tem mais por base a empatia, mas um estranhamento que permite arrancar o véu de familiar que obstrui a visão crítica da realidade. ${ }^{81}$

Encontravam-se nesse momento no Arlequins membros de duas gerações: alguns nascidos no início da década de 1950 - que viveram parte de suas infâncias e toda sua juventude sob botas e coturnos -, e outros nascidos no início da década de 1980 - cuja infância da qual ocorriam as lembranças provinham do governo Sarney ${ }^{82}$ na presidência e, posteriormente na escola, receberam poucas e superficiais informações sobre o sombrio período anterior da história político/social do Brasil.

Essa falta de informação despertou principalmente na "geração anos 1980" um enorme desejo de desvendar os processos, entender os fatos.

disso, teve sua execução proibida durante anos, pela ditadura militar brasileira. Tornou-se ícone de passeatas e manifestações populares.

${ }^{81}$ GARCIA, Silvana. Teatro da militância - A intenção do popular no engajamento político. São Paulo: Editora Perspectiva, 2004, p. 86.

${ }^{82}$ José Ribamar Sarney de Araújo Costa (1930-), vice de Tancredo de Almeida Neves - presidente eleito por colégio eleitoral (ou seja, não pelo voto popular) na transição da ditadura para a redemocratização -, assume em 1985 o cargo de Presidente da República do Brasil após morte de Tancredo. 
Partiremos da seguinte afirmação: "Aqui, o teatro é um meio - instrumento de ação política - que pretende tornar-se fim $^{83}$ - produto expressivo ideologicamente adequado de uma determinada categoria social." ${ }^{84}$ Vale ressaltar: um teatro deliberadamente político, pois o teatro sempre foi político, por condição ontológica. (Dort apud GARCIA) ${ }^{85}$

Definido o tema, seguimos com a temporada de pra Não dizer que Não falei das Flores e começamos a elaborar projetos buscando patrocínio que tornasse possível a produção do espetáculo. E essa fase levou mais de dois anos: participação em inúmeros editais nacionais, estaduais e municipais, até que em julho de 2008 nosso projeto foi aprovado pelo Programa Nacional de Cultura ${ }^{86}$. Depois de aprovado, mais um ano e meio para conseguirmos patrocinador para parte do projeto ${ }^{87}$.

Agora tínhamos um problema nas mãos: como utilizar os meios disponíveis e, ao mesmo tempo, inverter a lógica mercadológica?

Walter Benjamin chama à atenção os artistas para que assumam o controle de seus meios de produção e se tornem, eles mesmos, seus produtores, buscando assim não ficar escravos dos meios de produção da burguesia, o que obriga ao artista desenvolver obras comprometidas com aquela classe e sua ideologia. Benjamin afirma:

O caráter modelar da produção é, portanto, decisivo: em primeiro lugar, ela deve orientar outros produtores em sua produção e, em segundo lugar, precisa colocar à disposição deles um aparelho mais perfeito. Esse aparelho é tanto melhor quanto mais conduz consumidores à esfera da produção, ou seja, quanto maior for sua capacidade de transformar em colaboradores os leitores ou espectadores. Já possuímos um modelo desse gênero, do qual só posso falar aqui rapidamente. É o teatro épico de Brecht. ${ }^{88}$

Essa questão nos faz remeter ao tipo de relação, a forma de organização interna, e a relação com os meios de produção estabelecida no Arlequins desde seu surgimento, em

\footnotetext{
${ }^{83}$ Grifo da autora.

${ }^{84}$ GARCIA, Silvana. Teatro da militância - A intenção do popular no engajamento político. São Paulo:

Editora Perspectiva, 2004. p, 77.

${ }^{85}$ Ibidem, p. 77.

86 PRONAC, mais conhecido como "Lei Rouanet", é uma lei federal de incentivo à cultura através do mecanismo de renúncia fiscal.

${ }^{87}$ Entendemos que se faz necessário destacar as dificuldades e procedimentos a que os coletivos independentes, organizados como teatro de grupo estão expostos ao tentar viabilizar um projeto artístico, uma vez que no Brasil há meios escassos e insuficientes de financiamento público de bens culturais. Esse tema será recorrente em nossa descrição, pois entendemos que "no mundo precário do trabalho dos grupos de São Paulo, em que a luta de classes não é uma abstração teórica, em que os avanços estéticos nascem do enraizamento social na megalópole (esse laboratório avançado do capitalismo mundial" *, as escolhas temáticas e estéticas deste processo estão diretamente relacionados.

* Citação de CARVALHO, Sérgio de. Três vinténs: sobre o trabalho com Brecht no Brasil. Disponível em www.sergiodecarvalho.com.br.

${ }^{88}$ BENJAMIN, Walter. O autor como produtor (Conferência pronunciada no Instituto para o Estudo do Fascismo, em 27 de abril de 1934). In: Magia e técnica, arte e política: ensaios sobre literatura e história da cultura. São Paulo: Brasiliense, 2010, 1985, p. 129, 132.
} 
meados de 1970 quando nasceu o germe do grupo que em 1986 passou a se chamar Arlequins. A passagem do Núcleo Independente - originado no Núcleo Dois do Teatro de Arena - com seu trabalho de teatro jornal pela cidade de Guarulhos fortaleceu a continuidade do Grupo Perspectiva de Teatro Amador, formado por alunos secundaristas. Marotinho (1976), espetáculo de teatro-jornal sobre o despejo de uma favela em Salvador (com entrevistas de moradores e uma forte influência brechtiana), abriu novos horizontes. Em 1980, o grupo passou a se chamar Avis Rara, Avis Cara e, a partir de 1986, Arlequins, ambos da Cooperativa Paulista de Teatro.

Tais características são comuns a outros grupos contemporâneos ao Arlequins, tais como o Engenho, em seu início denominado Apoena, e que ainda têm em comum o fato "viver em certa contramão" do dito "mercado". Suas montagens não representam o mundo como conflito de personagens. Partem do pressuposto de que a vida não se resume a relações pessoais, afetivas, à psicologia e ao caráter desse ou daquele. E têm a convicção de que nem sempre historinhas pessoais, fábulas, dão conta de relações fundamentais entre os homens ${ }^{89}$.

Como descreve Alexandre Mate ao narrar os 30 anos de história da Cooperativa Paulista de Teatro, “[...] voltando à década de 1970, houve nesse momento intensos processos de luta. Dentre eles, um movimento de artistas, agrupados em coletivos autonomeados 'não empresariais' ou 'independentes' (que) promoveu um conjunto de ações que culminou na criação da Cooperativa" ${ }^{90}$, buscando organizarem-se para produzir em grupo, dentre os quais figuram os dois citados. Silvana Garcia salienta, ao analisar o trabalho de grupos de teatro popular dos anos 1970, outras características semelhantes a esses grupos, cuja "maioria [...] adota um sistema amador de sustentação financeira, cada membro mantendo sua sobrevivência por meio de trabalhos de diversas naturezas e dedicando-se ao teatro durante os períodos noturnos e fins de semana." 91

E foi buscando modificar um pouco essa ordem - (uma vez que também o Arlequins adotava até então o sistema descrito acima) - e ter condições de vida/produção um pouco mais estáveis que contribuíssem para avançarmos ainda mais em termos de linguagem estética (com mais tempo disponível para o trabalho teatral) que optamos por buscar meios de viabilização do projeto Geração AI-5 - Os filhos da Dita, conforme citado. Uma vez que tínhamos captado parte da verba necessária, podíamos dar início ao processo de montagem

\footnotetext{
${ }^{89}$ Descrição de características do Engenho Teatral e da mostra anual que promovem em seu espaço, disponível no blog do grupo: engenhoteatral.wordpress.com.

${ }^{90}$ MATE, Alexandre. Trinta anos da Cooperativa Paulista de Teatro - uma história de tantos (ou mais quantos, sempre juntos) trabalhadores fazedores de teatro. São Paulo, 2009, p. 76.

${ }^{91}$ GARCIA, Silvana. Teatro da militância - A intenção do popular no engajamento político. São Paulo: Editora Perspectiva, 2004, p. 126.
} 
propriamente dito. Em janeiro de 2010 iniciamos formalmente a montagem com aprofundamento e compartilhamento da pesquisa teórica que vínhamos, até então, desenvolvendo individualmente e sem critério comum definido. ${ }^{92}$ Neste momento o grupo de estudos contava com 3 atores e o diretor ${ }^{93}$ ao redor de mesas - ou em roda, ou caminhando... - intercambiando informações, buscando sanar dúvidas das leituras e pesquisas que continuávamos a fazer individualmente. Registrávamos então:

Quanto custa fazer teatro no Brasil? Com o atual sucateamento inevitável dos meios de produção nesse modelo de mercado onde arte é mercadoria, construímos o nosso teatro na precariedade. Mas esse é um projeto patrocinado pela Lei Rouanet, portanto com dinheiro público, então queremos prestar contas aos contribuintes. Teatro custa querer e depois mover e então crer que moveu, para querer de novo. E sempre. Custa se perguntar: para quê mover? Custa a aposta do público de que algo se moverá. Custa o tempo, que passa. Custa o apoio, que conseguimos nesses coletivos, públicos e privados. Obrigado. Algo se move.

Texto do programa da peça Os filhos da Dita

\footnotetext{
${ }^{92}$ Foi a primeira vez que trabalhávamos com a garantia de um cachê mensal para todas as funções, ainda em período de criação, ensaios etc. O que deveria ser corriqueiro na carreira artística - como trabalhadores que somos - nos causa até certo espanto dada sua raridade...

93 Neste momento a montagem contava com Ana Maria Quintal, Bruno Garcia, Camila Scudeler e Sérgio Santiago.
} 


\title{
3.1. PROCESSO COLABORATIVO
}

\begin{abstract}
A ditadura, com sua mirada única de barbárie e intolerância se foi... Com que olhos devemos olhar o que surgiu da maré em que se afogou mais de uma geração? Com os olhos da continuidade 'desenvolvimentista' verde-oliva do acordo que foi ficando amarelo? Com os olhos que viram romper a corda de um desenvolvimento que poderia ter sido mais igualitário? Com os olhos de acordo com o futuro, que não pode nem pensar na corda com que se enforcou a liberdade, para não comprometer o presente, comprometido com outras histórias? Com que olhos se deve ver? Bem abertos? Bem fechados? Com olhos de descobrir ossadas que talvez nem tenham sido enterradas? Com lágrimas secas de espantos e dores esquecidos? Com dor? Com alegria de haver passado? Com que olhos? Eis a questão.
\end{abstract}

Texto do programa da peça Os filhos da Dita

$\mathrm{Na}$ história do teatro ocidental, várias foram as formas de criação teatral desenvolvidas ao longo dos séculos. No entanto, nos interessa focar aqui nas experiências compartilhadas ${ }^{94}$ que servem como base para descrever o processo de criação posto em prática pelo Arlequins na montagem de Os filhos da Dita.

Para apresentarmos um breve panorama da criação a partir de processos coletivizados, optamos por utilizar o encaminhamento indicado por Antonio Araújo em sua tese de doutoramento, como veremos a seguir. ${ }^{95}$ A começar citando o processo inaugurado pelos Meininger, e as experiências desenvolvidas por Dântchenko, Stanislávski e demais encenadores-pedagogos vinculados ao Teatro de Arte de Moscou (TAM) - como Sulerjitski Araújo ressalta que foi a partir das experiências latino americanas de criação coletiva das décadas de 1960 e 1970 - sobretudo as empreendidas na Colômbia, em que se destacam as atuações do Teatro Experimental de Cali (TEC) e Teatro La Candelária ${ }^{96}$ - que se referencia o chamado processo colaborativo ${ }^{97}$, surgido como tal na década de 1990 . Historicamente

\footnotetext{
94 Fazendo importante ponte com principal referência deste trabalho, ressaltamos que Meyerhold - como nos conta Leach - ia à contramão do que era vigente no início do século XX e "[...] em nenhum momento da sua carreira como diretor apresentou aos atores um plano de produção definido no primeiro ensaio e passava então os ensaios subsequentes exercitando os atores para que eles pudessem reproduzir exatamente o que ele havia planejado. O 'plano' da produção era o produto final, ou ainda uma configuração em curso, acionada pelas improvisações dos atores". *

Citação de: LEACH, Robert. Stanislavsky and Meyerhold. Bern: Peter Lang, 2003, p. 57.

Meyerhold did not, at any time in his directing career, present the actors with a cut and dried production plan at the first rehearsal, and then spend the subsequent rehearsals drilling the actors so that they could reproduce exactly what he had planned. The production "plan" was the end product, or perhaps an ongoing configuration, thrown by the actors' improvisations.

95 Embora tenhamos optado por seguir as definições e descrições apontadas por Araújo, faz-se necessário salientar que o Teatro Popular é uma manifestação que na totalidade dos casos se dá, historicamente, em processo colaborativo.

${ }^{96}$ Destacamos também o trabalho desenvolvido pelo TUOV - Teatro União Olho Vivo, desde 1966, e do Grupo Teatro Escambray ( de Cuba), desde 1968.

${ }^{97}$ É este modo de criação compartilhada que dá régua e compasso para o processo de criação que aqui descrevo.
} 
situadas, as diferentes vertentes da criação teatral compartilhada apresentam a perspectiva coletivizada de construção da obra cênica, em que a autoria passa a ser comungada por todos, reconfigurada a dinâmica entre as funções artísticas. ${ }^{98}$

Trata-se, então, de um processo de criação em que os artistas envolvidos participam ativamente das decisões, ficando responsáveis por sua área de atuação. No entanto, “[...] a responsabilidade de cada um alcança não só a sua área específica de criação, mas também colabora na área do parceiro" ${ }^{99}$. Abreu esclarece:

Esse novo processo de criação não poderia conviver com o subjetivismo exacerbado que comumente acompanha o trabalho artístico. [...] Tudo é jogado numa arena comum e examinado, confrontado, debatido até o estabelecimento de um 'acordo' entre os criadores. É claro que esse acordo não significa reduzir a criação ao senso comum, nem transformar o vigor da criação artística num acordo de cavalheiros. É um acordo tenso, precário, sujeito, muitas vezes a constantes reavaliações durante o percurso. Confrontação (de ideias e material criativo) e acordo são pedras angulares no processo colaborativo. ${ }^{100}$

No Arlequins trazemos como herança principal dos processos de criação coletiva o fato de que "[...] os grupos de novo tipo de teatro (que trabalham métodos de criação coletiva) são grupos que adotaram o ponto de vista dos trabalhadores, sua forma de organizarse"101 102 , como nos conta Carlos José Reyes.

No que tange à criação dramatúrgica de Os filhos da Dita, a mesma foi desenvolvida - escrita e reescrita diversas vezes - durante o processo. Foi construída a partir do palco, em diálogo com ele. "Uma regra geral no processo colaborativo: tudo deve ser testado em cena, sejam ideias, propostas ou simples sugestões". ${ }^{103}$

Após somente 2 semanas nas quais nos dedicamos exclusivamente a estudos de mesa, buscando criar uma base comum de dados iniciais que possibilitasse a todos participarem ativamente de todo o processo de criação, em fevereiro de 2010 começamos a experimentar cenicamente o que vínhamos pesquisando e a raciocinar no palco, termo muito usado pelo diretor. Após aquecimento livre, seguido de indicações do diretor liderando um aquecimento coletivo, partíamos quase sempre para improvisação livre, tendo apenas o tema

\footnotetext{
${ }^{98}$ ARAÚJO, Antonio. A Encenação no Coletivo: desterritorializações da função do diretor no processo colaborativo. Tese de doutoramento. ECA-USP, São Paulo, 2008.

${ }^{99}$ ABREU, Luís Alberto de. Processo colaborativo: relato e reflexões sobre uma experiência de criação. $S / R$ (artigo não publicado), p. 40.

${ }^{100}$ Ibidem, p. 36.

${ }^{101}$ REYES, Carlos José. La creación colectiva: una nueva organización interna del trabajo teatral (1974). In: El Teatro Latinoamericano de Creación Colectiva. Ciudad de La Habana: Casa de Las Americas, 1978, p. 77.

${ }^{102}$ Los grupos de Nuevo tipo de teatro que trabajan metodos de creación colectiva significan, por lo tanto, grupos que han adoptado el punto de vista de los trabajadores, su forma de organizarse.

${ }_{103}$ ABREU, op. cit., p. 39.
} 
geral como mote: podia-se recorrer a algum fato histórico pontual, personagem marcante, releitura do período, crítica de uma situação específica... Improvisação é análise, e exige um grupo com pensamento crítico, com conhecimento intelectual. Trata-se de atirar-se no abismo e ir construindo as asas enquanto se está caindo. Tamanha "liberdade" e abrangência davam um sabor de angústia a esse processo, e a ansiedade dos atores pulsava... ${ }^{104}$

Algumas diretrizes, no entanto, estavam claras para todos os envolvidos no processo criativo: a peça seria fragmentada (característica marcante e recorrente no trabalho do Arlequins, uma vez que esse formato não exige criação de personagens fixas, rompe com ação linear, ficava claro que não haveria fábula contínua nem personagens marcados a percorrê-la toda); não teria caráter demasiadamente escolar/didático (mesmo tratando de um período histórico); seria necessário fazer escolhas pontuais quanto a que aspectos priorizar em nossa narrativa (dada a impossibilidade de lidar de outra maneira com material tão abrangente e complexo); buscaríamos aprofundar o caráter narrativo e explorar distintas formas de utilizá-lo (pesquisa antiga do grupo).

Surge um dos primeiros insights, de origem fantástica: uma situação fíctícia serviria de metáfora do golpe e de mote para chegarmos até os dias atuais - o parto, de uma mulher chamada Dita ocorre em meio à Avenida Brasil na cidade do Rio de Janeiro no dia $1^{\circ}$ de abril de 1964. A confusão ficava por conta das tropas militares que aguardavam ordens para definir se dariam suporte ou não ao golpe, iniciado pelo General Olímpio Mourão Filho a caminho do Rio de Janeiro, vindo de Juiz de Fora, Minas Gerais. Uma criança nasce em meio a essa situação: acompanhar a trajetória de vida desse "filho da Dita" serviria de ligação entre as inúmeras situações ocorridas nos 47 anos seguintes. Esse primeiro elemento foi sendo, ao longo do processo, redimensionado e modificado.

Já a definição de quais episódios retratar e que figuras ressaltar foram perguntas que fomos aos poucos tentando responder. Embora a equipe de dramaturgia tivesse o pressuposto da definição, os processos de brainstorming e proposições ocorreram no coletivo. $^{105} 106$

\footnotetext{
${ }^{104}$ A sensação de estar a um passo do abismo e sentir-me impotente era constante. Mas o diretor insistia - e insistiu até o final - na construção da peça a partir desse processo, de construção de dentro do palco, o que resultou efetivamente em um trabalho intensamente autoral.

${ }^{105}$ Bruno Garcia participou do projeto de janeiro a setembro de 2010, com as funções principais de ator e preparador corporal. Sua saída se deu por decisão pessoal.

${ }^{106}$ Em março de 2010 somou-se à montagem Danielle Agostinho, como parte do elenco. Tendo participado do processo de definição do tema e de montagem de projetos que viabilizassem sua execução, deu à luz no início de fevereiro, e trazia seu filho aos ensaios, situação atípica e que trouxe novo tom à criação. Até outubro do mesmo ano ela permaneceu na função de atriz, tendo depois comunicado ao grupo a impossibilidade de continuar com tal função, passando assim a produzir o DVD que registra este processo - material que é parte integrante do
} 
O fato de não ter (até novembro de 2010, pelo menos) um texto acabado, tornava o processo estimulante, mas por muitas vezes a ansiedade tomava conta... 


\subsection{APROXIMAÇÃO AO TEMA}

O aprofundamento dos conhecimentos do grupo acerca da temática que optamos por tratar deu-se de inúmeras formas: através de livros, revistas, filmes, documentários, mas também estudos, palestras, debates, conversas, visitas a memoriais etc...

Dentre eles, vale destacar os encontros - abertos e fechados ao público - de estudo e aprofundamento que tiveram importantes nomes colaborando com nossa compreensão do período.

A série de debates Segundas Opiniões, aberta ao público em geral, foi realizada em setembro e outubro de 2010. Tratou-se de uma série de encontros marcados para discutir a ditadura militar brasileira e seus desdobramentos contando com a presença de Paulo Arantes $^{107}$, Iná Camargo $\operatorname{Costa}^{108}$, Ana Martins ${ }^{109}$ e Ivan Seixas ${ }^{110}$.

Já os encontros internos, intitulados Arlequins encontra, tiveram como objetivo rastrear, do ponto de vista econômico, a era Getúlio Vargas até os dias de hoje, com ênfase no chamado Milagre Brasileiro (período que foi de 1968 a 1973). Para tanto contamos com Antonio Tadachi ${ }^{111}$ e Luiz Carlos Scapi. ${ }^{112} 113$

\footnotetext{
${ }^{107}$ Filósofo, professor aposentado do Departamento de Filosofia da Universidade de São Paulo. Autor de O Fio da Meada (1996), Zero à esquerda (2004), Extinção (2007) e artigo intitulado 1964- o ano que não terminou do livro $\mathbf{O}$ que resta da ditadura (2010), entre outros.

${ }^{108}$ Dramaturgista do grupo Ocamorana, é pesquisadora de teatro e professora aposentada de Teoria Literária da USP. Autora de A hora do teatro épico no Brasil (1996), Sinta o drama (1998), entre outros estudos sobre as relações entre forma teatral e política.

${ }^{109}$ Viúva de Antonio de Almeida Soares (Tom), que foi padre e militou na JOC (Juventude Operária Católica). Militante do Partido Comunista do Brasil, Tom foi preso e passou pela ante sala de torturas do DOPS. Juntamente com seu companheiro, Ana foi viver no interior da Bahia desenvolvendo trabalho popular de apoio a guerrilha do Araguaia.

${ }_{110}$ Jornalista e presidente do Núcleo de Preservação da Memória Política do Fórum Permanente de ex-Presos e Perseguidos Políticos de São Paulo.

${ }^{111}$ Economista.

${ }^{112}$ Educador popular do Núcleo 13 de Maio e do Fórum Nacional de Monitores.

${ }^{113}$ Para maiores informações sobre os eventos que fizeram parte do projeto Geração AI-5 - Os filhos da Dita, acessar blog do projeto: geracaoai5.blogspot.com.
} 


\subsection{PESQUISA PRÁTICA - A BIOMECÂNICA NO ARLEQUINS}

Dado o objeto deste trabalho, minha criação como atriz, optei por focar aqui o espaço e a liberdade que encontrei no Arlequins e que foram imprescindíveis para que pudesse desenvolver as cenas do espetáculo aqui descritas: as proposições se deram dentro de um processo horizontal de criação, no qual interferi diretamente e encontrei respaldo e sustentação por parte da direção e dos demais atores que participaram do processo.

Vamos por partes... A começar pelo meu interesse em aprofundar-me no treinamento psicofísico da biomecânica, já em 2007. Com meu "conhecimento" acerca da vida e obra de Meyerhold, limitado ao (pouco) contato que tive por meio de textos - nenhuma vivência prática - durante a graduação, decidi buscar meios de conhecer um pouco mais de perto, e experimentar no corpo proposições que sempre me pareceram muito instigantes. Desde o início, minha sugestão despertou em Sérgio Santiago ${ }^{114}$ particular interesse principalmente dada a amplitude e eloquência da poética pensada por Meyerhold em seu papel de encenador-pedagogo junto a seus alunos e atores - propondo-se inclusive a participar de oficinas práticas. Já Ana Maria Quintal ${ }^{115}$, apesar de sempre estimular minha pesquisa individual, viu com certa desconfiança uma possível 'obrigatoriedade' de utilização dos princípios, quando minha pesquisa se configurou num trabalho acadêmico, com necessidade de 'comprovação' em cena... Nada contra, por sua parte, desde que não a incluísse nessa 'obrigatoriedade'... A ela interessa mais a máxima do Arlequins - que influenciou inclusive a escolha o nome do grupo quando essa se deu: a liberdade de lançar mão de qualquer poética, técnica, estética que venha a contribuir na construção e transmissão de seu fazer teatral, assim como a roupa do Arlequim ${ }^{116}$ é composta por uma verdadeira colcha de retalhos que lhe confere personalidade - daí a inspiração ao nome.

No entanto, desde o início da montagem deste espetáculo, o treinamento de biomecânica fez parte da rotina de criação do grupo. Num primeiro momento tendo como propositor o ator Bruno Garcia (enquanto fez parte do elenco), e a partir de novembro de 2010 em encontros com Yedda Carvalho Chaves ${ }^{117}$ - importantíssimos para a compreensão e experimentação dos princípios norteadores da biomecânica em cena.

\footnotetext{
${ }^{114}$ Diretor e dramaturgo do grupo.

${ }^{115}$ Atriz e dramaturga e produtora do grupo.

${ }^{116}$ Personagem da commedia dell'arte.

117 Professora e pesquisadora do Departamento de Artes Cênicas da Escola de Comunicações e Artes da Universidade de São Paulo, doutora em Estudos Teatrais pela Universidade de Paris III - Sorbonne Nouvelle, sob orientação da professora Béatrice Picon-Vallin, especialista em estudos sobre Vsévolod Meyerhold, e co-
} 
Além das constatações - inclusive formais - mais evidentes e facilmente identificáveis nas cenas que descrevo em pormenores no próximo capítulo e cujos registros fotográficos estão aqui reproduzidos, é possível vislumbrar vestígios da poética proposta por Meyerhold - e revisitados pelos Arlequins: nuances de atuação das duas atrizes, escolha e utilização de objetos, desenho do palco, uso da musicalidade, exploração de espaços cênicos potenciais, jogo com níveis, com o público, opções de utilização de iluminação, projeções, sonoplastia... Vestígios de um processo que foi assimilado com suas próprias nuances...

Um texto de Ana Maria Quintal perpassa os pontos destacados:

"Nem os mortos vão estar a salvo enquanto o dominante estiver vivo." Walter Benjamin

No Arlequins fazer o teatro político (épico-dialético) leva em consideração que certamente sofreremos uma certa resistência daqueles que assistem a esse tipo de narrativa com resquícios de uma visão do drama. As ferramentas disponíveis de observação e crítica de uma maneira geral não contemplam essa outra forma, e ao assistir produções alternativas com elementos do drama, esse ato sempre será frustrante ou embaraçoso. Forma não depende de ser antiga ou nova ela tem que ser adequada para o conteúdo a ser organizado. Usar a verossimilhança como argumento de validade é cair no atoleiro dos conceitos que preservam o drama. Por isso a escolha na nossa poética em explicitar o processo de criação, todas as nossas apresentações são experimentais, - como assim? (perguntarão alguns) - respondo, citando Iná Camargo Costa "[...] por que vetar aos artistas a possibilidade da experiência como aos cientistas?". Então, é isso, estamos sempre em processo, e o público passa a ser co-autor no nosso espetáculo. As suas dificuldades e inquietações são estímulos para a nossa criação.

Para que estejamos aptos e não defendidos para essa experiência precisamos de uma prontidão, adquirida pelo treinamento cotidiano de nosso aparelho (corpo e voz) que potencializa nossa capacidade de movimentação e constrói a possibilidade de manifestarmos a nossa expressão política que justifica o nosso fazer teatral. Nesse espetáculo, Os filhos da Dita, a biomecânica de Meyerhold é a principal ferramenta utilizada. Ela possibilita que o gesto final mostre a síntese das perturbações que o geraram com o distanciamento indispensável, isto é o que precisávamos para tratarmos de um assunto tão doído e cruel como o golpe militar brasileiro de 1964, e não podíamos permitir a simples identificação emocional do público, o que seria imediato, já que a ditadura é um inimigo reconhecido por todas as classes. A utilização dessa gestualidade permite que a construção do pensamento venha como resultado do confronto (dialético) entre as forças envolvidas. O presente é para iluminar o passado, isso é épico. Absolutamente impecável!

Ana Maria Quintal

orientação do professor e neurofisiologista Alain Berthoz, e mestre em Artes Cênicas pela Universidade de São Paulo. 
Paralelamente ao raciocinar em palco, reservamos parte de nossos encontros para, além do treinamento psicofísico a partir de princípios da biomecânica de Meyerhold ${ }^{118}$, o trabalho sobre conceitos musicais e seus desdobramentos, e o trabalho a partir das técnicas de máscara neutra ${ }^{119}$.

\footnotetext{
${ }^{118}$ Para descrição detalhada da relação e aprofundamento pessoal em relação à biomecânica, ver item 4.1 deste trabalho.

${ }^{119}$ A máscara neutra possibilita aprofundar e aprimorar o potencial expressivo do artista, através da ação de um corpo vivo e presente, tendo o ator como criador da expressão teatral. Busca-se com elementos desta técnica, desenvolvida por Jacques Lecoq, a preparação do ator para o trabalho, a limpeza de vícios expressivos e trejeitos, explorar a disponibilidade do ator através da escuta, visão e percepção, no tempo presente, a concretude expressiva do corpo, a relação com o espaço, com objetos e com outros. A máscara neutra em Copeau contribuiu para ultrapassar a convenção pantomímica do gesto que traduz as palavras; desenvolver as qualidades dinâmicas do movimento, ritmo e intensidade; utilizar o princípio da independência articular e muscular do corpo.
} 


\section{Registro de treinamento de biomecânica para montagem de Os filhos da Dita Experimentação de princípios e trabalho com études}
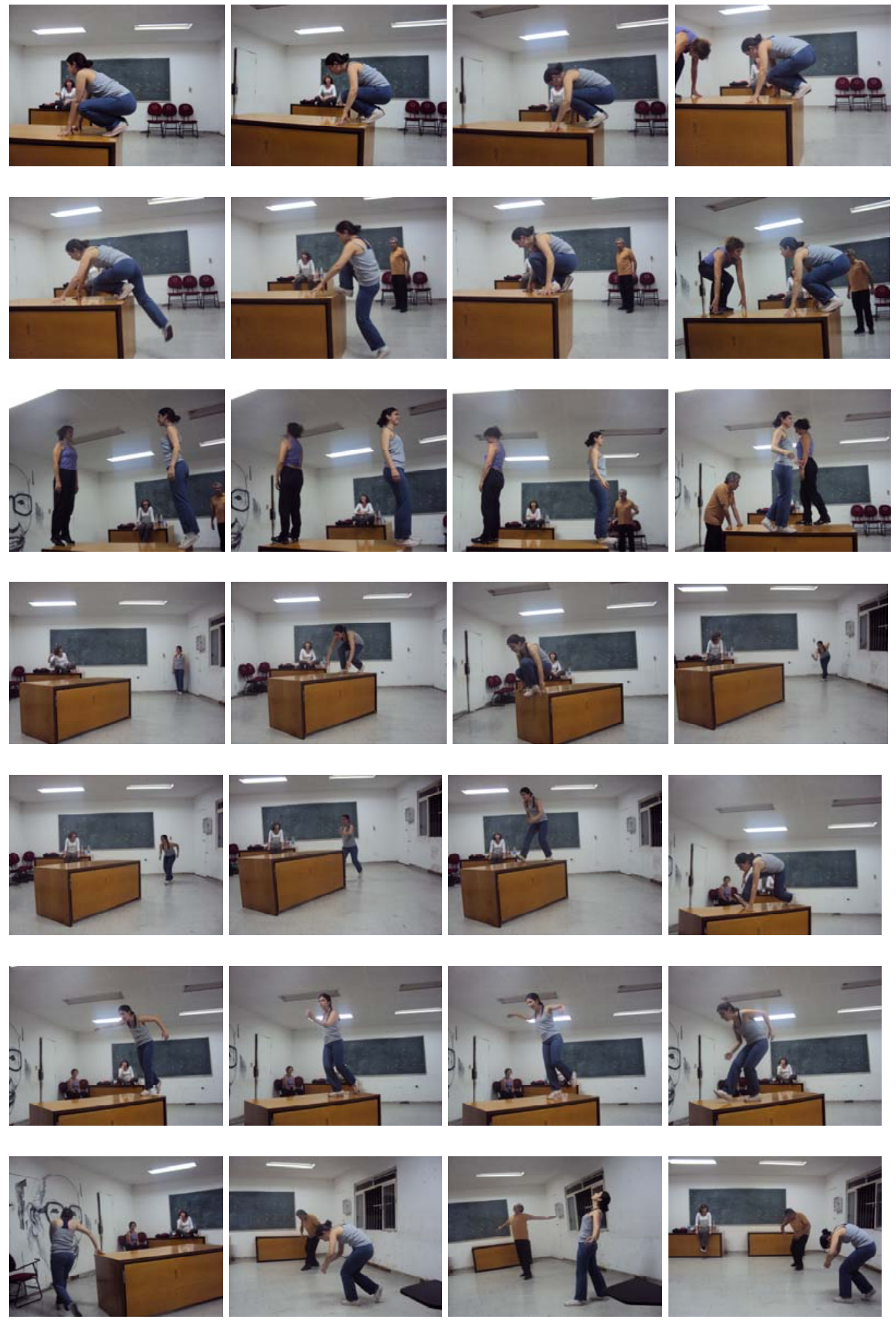

Sequência de fotos 1 - exercícios que estimulavam a destreza, equilíbrio, prontidão e desenvoltura.

Nas fotos: Camila Scudeler, Ana Maria Quintal e Sérgio Santiago - efetuando os exercícios e Yedda Carvalho Chaves - ministrando o treinamento

Local: Auditório Castro Alves / São Paulo

Período: novembro / 2010

Crédito: Danielle Agostinho. 


\section{Étude “Golpe com adaga”}
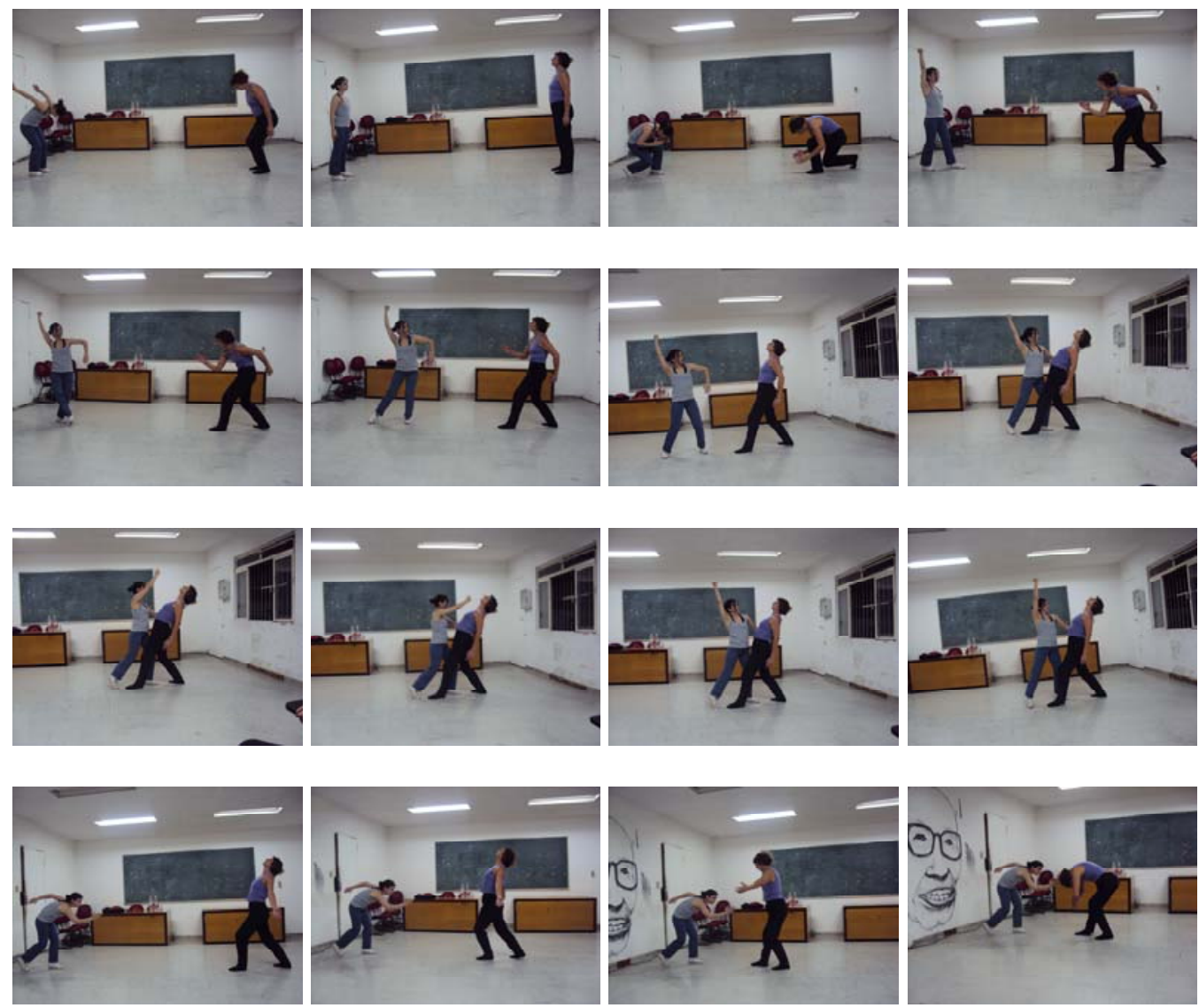

Sequência de fotos 2 - execução do étude "Golpe com adaga" Nas fotos: Camila Scudeler e Ana Maria Quintal e

Local: Auditório Castro Alves / São Paulo

Período: novembro / 2010

Crédito: Danielle Agostinho. 


\subsection{ALGUNS PROCEDIMENTOS}

No processo de construção cênica da "Dita" o espetáculo vai emergindo, primeiramente, do desenho rítmico na fala, no falar. A perspectiva mirada é a de narrar com todo o corpo, além da própria voz, mas o andaime por onde se começa a descobrir o espetáculo é a palavra falada. Numa fase inicial isso conduz a um excesso. De palavras, claro. Que devem ser substituídas na medida em que a utilização mais ampla da ação física o permita.

Sérgio Santiago

Embora não seja objeto deste trabalho a descrição dos procedimentos desenvolvidos e empregados pelo Arlequins há mais de 25 anos de trabalho contínuo ${ }^{120}$, optei por descrever alguns daqueles que foram marcantes nesse processo.

\section{Procedimento 1}

No início desses estudos, antes de nos aprofundarmos no tema, Ana Maria Quintal pediu que eu e Bruno Garcia (representantes da geração de 1980), expuséssemos o que sabíamos, tínhamos ouvido falar, estudado em nosso tempo de escola sobre a ditadura - um período que não tínhamos vivenciado. ${ }^{121}$ Desde o início foi rico perceber, a partir de nossos

\footnotetext{
${ }^{120}$ Desde 1986 o grupo optou por montar obras de alguns dos mais importantes dramaturgos mundiais, assim como desenvolveu dramaturgia dentro do próprio núcleo quando necessário. Destacam-se como montagens mais significativas: Medida por Medida, de William Shakespeare; Casa de Bonecas, de Henrik Ibsen; Orfeu Despedaçado, de Éjo de Rocha Miranda; O Ar que é do Arco-Íris, de Maria do Rosário; Certas Palavras, de Ana Maria Quintal; Depois daquele Beijo, de Éjo de Rocha Miranda; Muito Prazer, de Ana Maria Quintal; pra Não dizer que Não falei das Flores, de Éjo de Rocha Miranda e Ana Maria Quintal; Castro Alves - Livre, de Éjo de Rocha Miranda.

${ }^{121}$ Incluo aqui trecho do meu caderno de anotações no qual guardei este exercício. A fim de aproximar o leitor à pessoalidade e informalidade do texto, optei por utilizar fonte que remete à letra cursiva.

Como estava envolvida neste processo há alguns anos já tinha me aprofundado um pouco mais, e tido acesso a inúmeros materiais. No entanto fiz este exercicio buscando minhas sensaçóes anteriores, meus conhecimentos prévios a esse momento. Reproduzo aqui algumas dessas lembranças, pontuando situações que me marcaram.

Ponto 1: Nascida em agosto de 1981, não tinha 4 anos completos quando da morte do quase Presidente da República Tancredo Neves (anunciada em 21 de abríl de 1985). No entanto, lembro-me com clareza da comoção mostrada incessantemente com muito sensacionalismo pelas emissoras de televisão ao
} 
próprios relatos, as impressões que nossas famílias tinham do período, as marcas sofridas por alguns professores... Deparei-me com certa ideia romantizada que tinha daquelas situações, um resquício de meus devaneios adolescentes e certa nostalgia por ter nascido em um momento em que os estudantes já não estavam organizados, a sociedade não mais se mobilizava coletivamente etc... Buscou-se com esse procedimento resguardar informações, impressões de pessoas com pouco (ou nenhum) contato com o assunto - condição provável da maioria dos espectadores com os quais viríamos a nos deparar posteriormente - antes de mergulharmos nas informações que a pesquisa nos traria.

ponto de minha mãe chegar em casa e ew estar aos prantos no sofá. Qual não foi sew espanto ao saber que o motivo do choro era a morte do Dr. Tancredo! Ponto 2: $\mathcal{O}$ ano era 1989, tinha 8 anos, e tios que moravam em São Bernardo do Campo. Estar no berço do movimento operário durante o segundo turno da eleição presidencial (em 17 de dezembro), a primeira direta desde 1960, foi certamente marcante. Fomos diversas vezes ao comitê do Partido dos Trabalhadores buscar adesivos da campanha de Lula, sempre com $\sigma$ slogan Lula lá, nasce uma estrela.. Faziamos bandeirinhas, que colocávamos para fora da janela do carro, orguthosos ao passear pela cidade. Fui votar com meus tios, coloquei $\sigma X$ para Lula e sai dali radiante. Qual nã $\sigma$ foi minha imensa decepção quando, à noite liguei para meus pais e minha mãe me disse ter votado em Fernando Collor de Mello. Mais uma vez, sem entender o que aquilo significava ao certo, as lágrimas foram mew único consolo...

Ponto 3: Já no ensino médio (chamado então de colegial) tive uma professora de história sensacional, e suas histórias - principalmente aquelas que ilustravam suas andanças e vívências durante a ditadura militar exerciam certo fascínio sobre mim. Lembro-me dos relatos sobre seu periodo como universitária, encontros clandestinos de estudantes, a policia por todos os lados... Recebia tudo aquilo com um alto graw de romantismo, com uma nostalgia de um passado ideatizado...

Apesar de toda a nação ter sofrido com os desmandos dos generais e toda a estrutura civil e militar que thes dava suporte nas mais diversas áreas (económica, social, cultural etc), há certo senso comum segundo o qual as atrocidades foram sofridas somente nas grandes capitais, e somente por membros de organizaçóes de esquerda que insistiam em se contrapor ao regime imposto. No entanto, as restriçóes impostas pelo regime de exceção atuavam categoricamente em cada canto desse pais. No interior, atividades corriqueiras (até hoje, mas mais ainda naquele então) como jogos de baralhos em botecos passaram a ser proibidos, por serem considerados reunióes - ato subversivo que consta no Ato Institucional no 5 de 13 de dezembro de 1968. Tal impedimento é um dos fatos que meu pai se recorda ao analisar o periodo da ditadura em Santa Cruz do Rio Pardo.

Meu pai vivenciou também a fúría dos policiais e sens cavalos sobre professores e estudantes que se manifestavam no centro da cidade de São Paulo em 1969. 


\section{Procedimento 2}

Pesquisa buscando distintas e eficazes maneiras de fazer o deslizamento do discurso direto para o discurso indireto ${ }^{122} /$ narração. Tal busca está embasada na seguinte máxima, destacada por Rosenfeld:

O ator épico deve "narrar" seu papel, com o "gestus" de quem mostra um personagem, mantendo certa distancia dele. Por uma parte da sua existência histriônica - aquela que emprestou à personagem - insere-se na ação, por outra mantém-se à margem dela. Assim dialoga não só com seus companheiros cênicos e sim também com o público. Não se metamorfoseia por completo ou, melhor, executa um jogo difícil entre a metamorfose e o distanciamento, jogo que pressupõe a metamorfose. Em cada momento deve estar preparado para desdobrar-se em sujeito (narrador), mas também para 'entrar' plenamente no papel, obtendo a identificação dramática em que não existe a relativização do objeto (personagem) a partir de um foco subjetivo (ator). Que o distanciamento pressupõe a identificação - pelo menos nos ensaios - foi destacado por Brecht [...]. Na medida em que o ator, como porta-voz do autor, se separa do personagem, dirigindo-se ao público, abandona o espaço e o tempo fictícios da ação. ${ }^{123}$

Durante todo o processo de montagem de Os filhos da Dita esteve presente a pesquisa acerca da narratividade - tanto buscando os porquês da escolha por essa forma de contar nossa história quanto experimentando distintas maneiras de utilizá-la. O trabalho do Arlequins é embasado na apresentação do ator-narrador que, mesmo ao fazer uma personagem dela se distancia afim de colocar seu ponto de vista, sua crítica.

Ao distanciar-se do personagem, o ator-narrador, dividindo-se a si mesmo em 'pessoa' e 'personagem', deve revelar a 'sua' opinião sobre este último; deve 'admirar-se ante as contradições inerentes às diversas atitudes' do personagem [...]. Assim o desempenho torna-se também tomada de posição do 'ator', nem sempre, aliás, em favor do personagem. O ponto de vista assumido pelo ator é o da crítica social. ${ }^{124}$

Tal procedimento aparece em distintos momentos da peça, mas vale ressaltar a primeira cena (do espetáculo que temos atualmente, já "acabado") em que aparecem juntas as duas atrizes. Uma vez que o prólogo é composto por duas cenas individuais, a função principal é exatamente apresentar as duas narradoras as quais (em texto que ironiza o tempo

\footnotetext{
${ }^{122}$ Segundo as regras da língua, em se tratando de língua escrita, o discurso é direto quando são as personagens que falam. O narrador, interrompendo a narrativa, põe-nas em cena e cede-lhes a palavra. No discurso indireto não há diálogo, o narrador não põe as personagens a falar diretamente, mas faz-se o intérprete delas, transmitindo ao leitor o que disseram ou pensaram. Em se tratando de teatro, texto falado, é preciso ficar claro para o espectador esse jogo entre narrador/personagem.

${ }^{123}$ ROSENFELD, Anatol. O teatro épico. São Paulo: Perspectiva, 2006, p. 161.

${ }^{124}$ Ibidem, p. 162.
} 
atual $^{125}$, o hoje) explicitam que irão olhar para um tempo anterior a fim de iluminar e ampliar as possibilidades de percepção dos tempos atuais.

Iniciado o processo em janeiro de 2010, em dezembro do mesmo ano saímos em duas ocasiões da sala de ensaio para compartilhar o que estávamos concretizando, tendo no elenco Ana Maria Quintal e Camila Scudeler - formação que se mantém. Voltamos a trabalhar em sala e em 16 de março de 2011 estreamos a temporada experimental ${ }^{126}$ e em 7 de maio de 2011 a temporada oficial ${ }^{127}$ de Os filhos da Dita.

\footnotetext{
${ }^{125}$ Texto inicial do espetáculo (ver anexo B para dramaturgia completa): "Eu sou de um tempo que, assim, quando alguém falava já não era mais fala de gente, era fala da sociedade civil. Eu sou de um tempo em que a tragédia e a dor já tinham se transformado em discurso, a década perdida e a dor - ridícula - a ser esquecida; eu sou do tempo em que o próprio tempo ia acabar, num nunca mais ser de novo qualquer coisa, e qualquer coisa ia acabar antes da noite que ia descer, que ia descer; Eu sou do tempo, feito de mais valia.”

${ }^{126}$ O projeto Geração AI-5 - Os filhos da Dita previa 30 apresentações gratuitas em escolas públicas das distintas regiões da cidade de São Paulo. Esta temporada teve como característica principal a possibilidade de uma troca mais próxima com o espectador uma vez que se tratava de abertura de um processo ainda não totalmente fechado, e que estava, portanto, definindo certos encaminhamentos. Esta relação - tanto durante a peça quanto nos debates/conversas que aconteciam ao final - foi responsável por alterações de texto, ordem de cena, criação de novas etc (maiores detalhes a respeito dessa mútua interferência no item 5.1 deste trabalho). De 16 de março a 02 de junho de 2011 completamos todas as apresentações, envolvendo um total de 8.949 espectadores entre alunos, professores e funcionários das escolas (para lista completa das escolas contempladas ver anexo C). As apresentações aconteceram nas próprias escolas (pátios, refeitórios, quadras, auditórios), e com exceção ao CIEJA Sapopemba, escola localizada em frente ao CEU Sapopemba (Centro de Educação Unificado da cidade de São Paulo), e que foi possível apresentar no teatro da instituição.

${ }^{127}$ A temporada oficial ocorreu de 07 a 29 de maio de 2011 no Teatro Coletivo, na cidade de São Paulo, com 8 apresentações.
} 


\subsection{TRABALHO DE MESA - O\& fühos da Díta}

Após as alterações de elenco citadas, e com data de estreia da temporada experimental já definida, optamos por dedicar alguns dias de nossos encontros ao que denominamos trabalho de mesa. Neste momento, tratava-se de analisar o material que tínhamos construído ao longo de um ano de trabalho e definir nomenclaturas comuns às cenas, os seus 'tons' e, dessa maneira, poder inclusive diagnosticar eventuais problemas.

Por ter sido um procedimento muito produtivo e ilustrativo do processo, optei por incluí-lo aqui, utilizando (assim como na nota de rodapé 121) uma fonte que remete à letra cursiva, à minhas anotações à mão - uma vez que o que está aqui retratado é a minha forma de entender o processo. ${ }^{128}$ Ele serve, ainda, como uma espécie de roteiro do espetáculo.

$01 / 02 / 2011$

- Palavra: SINTAGMA ${ }^{129}$

- Partituratonal

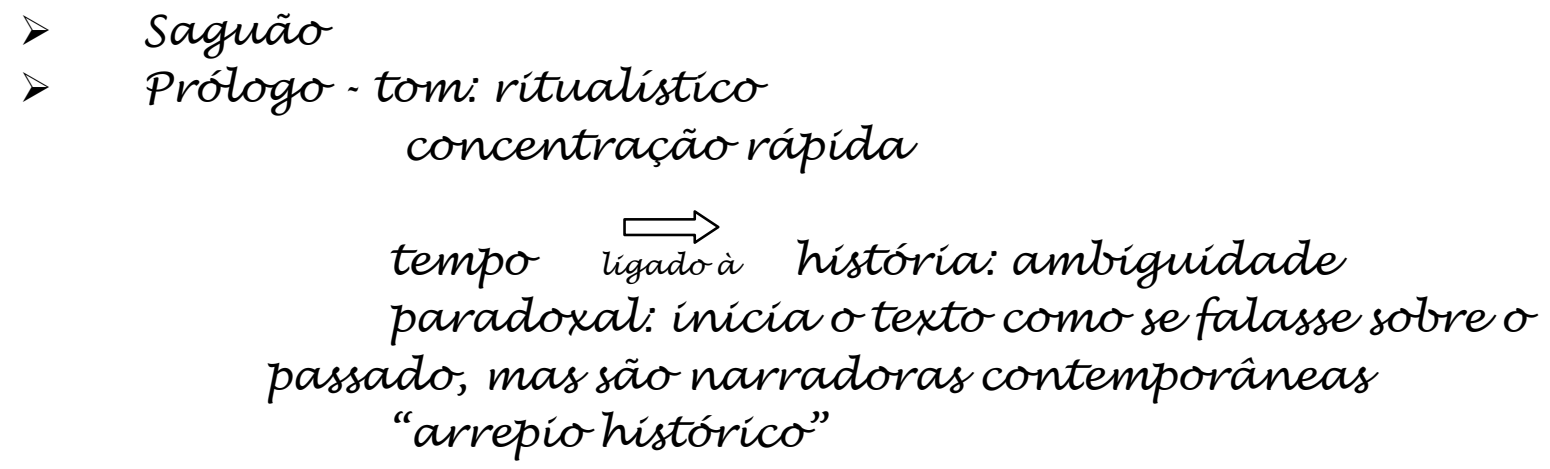

- Luz sobre o cravo - condensa o significado do prólogo, prepara a expectativa, focaliza

\footnotetext{
${ }^{128}$ Anotações de temas, palavras-chave, sem necessidade de concatenação sintática. Embora o material de cada um dos participantes, resultante das conversas, fosse sempre comparado, desde que a ideia principal, a função da cena tivesse o mesmo sentido, mantivemos nossas próprias palavras. Depois desse procedimento o espetáculo seguiu sofrendo alterações, e algumas cenas aqui descritas não foram mantidas no espetáculo - tendo sido cortadas ou substituídas.

129 Segundo o Dicionário Aurélio, Sintagma é um segmento linguístico que expressa uma relação de dependência. Nessa relação de dependência, diz-se que existe um elemento determinado e outro determinante, estabelecendo um elo de subordinação entre ambos. Cada um desses elementos constitui um sintagma. Na concepção original de sintagma, essa noção era utilizada para se referir a qualquer segmento lingüístico: a palavra, a sentença e o período. Mais recentemente, o temo sintagma tem sido mais comumente empregado para se referir às partes da sentença.
} 
$>$ Coturnos

Canção do expedicionário: - o oupação/invasão

- louca

- parto

- Invasão-tom: apressado, opressivo, ansioso

Músicas entrecortadas por falas de contenção/suspensão

- Louca - tom: premonição/euforía

Muda a cena, puxa para ela a narrativa

Quebra a narrativa

* Parto-tomi crueza

partir, separar, nascer

- Cabos-tom: indecisãol indefinição

Confusão / clownesco

(quebra para inclusão de informaçöes que nã ficaram claras nas falas dos cabos)

$>$ Sargento trás a louca - tom: absurdo

louca cría espaço atemporal/ apresenta-se como Dita

$>$ Congestionamento telefónico - tom: congestionamento

sonoro

$02 / 02 / 2011$

tons de voz, variações

$1^{\circ}$ de abril - vinheta de ligação

tom: pegadinhal brincadeira

$>$ Jango-tom: derrota/melancolia

fim do dia, fim de feira

> Black out: vinheta/escuro 
> Tempestade: tempestuosa

$>$ Lanternas:

- 19 parte: Iara na cela - tom: tempestade de ódio

Luz que procura fugitivolódio

- 2a parte: procissão das datas - tom: desrespeitoso/teatro de revista fogueira/papel rasgando notas para Camila: cantar as datas, cantar VI-TÓ -RI-A baixando otom

fogueira: abre luz e fecha com a leitura de manchete da imprensa no dia 02 de abril de 1964

- Pêndulo: luz pendular - tom: dívidas, procura As dividas explodem para plateia, para $\sigma 3^{\circ}$ abajur

- Coro dodecafónico: recorrente na peça/dele emerge tudo

- Panorama/ O baile-tom: grotesco

sangue/ hígubre/baile de vampiros do famitiar para o inesperado

$\longrightarrow$ Baile: os que deram o golpe

4 Crise: outros lados

- Crise: as coisas não têm um lado só - tom: dualismo irônicolexplosóes reprimidas/suspiros guardados abrir o leque de conteído othos

Iara lança mão de criar tipos, dialogar com eles, eles dialogarem entre si

- Apresentação da missa negra-vinheta de ligação

chicotes com a luz

falsa mistica

exorcizaçãoé $\sigma$ füm

> Missa negra-tom: decrépitol seres 'doentes'solene/cadenciamento fúnebrelesotérico desenho definido 
- Diagonal da equilibrista - tom: baixa rotação/câmera lenta/suspensão

ponte de ligação/preparação

na corda bamba: a esperança

> Milagre-recintos:

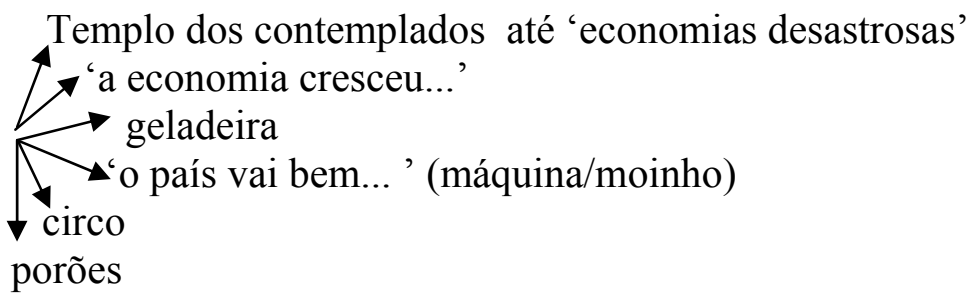

- Templo dos contemplados - tom: circol up and down

- Alameda Casa Branca - tom: tributollembrar e enterrar os mortos

$$
\text { fecha-abre: simbólica }
$$

$08 / 02 / 2011$

$2^{\circ}$ tempo

- Fantasmas (cela II) - tom: conclusivo/não cría dívidas/cqd ponte do final do $1^{\circ}$ para $2^{\circ}$ tempo recriação/continuação dos 'procedimentos' da Iara

* destizamento da narradora para Iara, como se a narradora percebesse o que estava por trás do milagre, e ao adentrar nos poróes encontra Iara

* necessidade da Dita

$>$ Invenção - tom: ansiedade/tensão (ex: pesagem de lutadores antes da luta)

$$
\begin{aligned}
& \text { justifica a criação da Dita } \\
& \text { criar o inimigo e se subjugar } \\
& \text { já que desceu ao inferno, abrace o capeta' }
\end{aligned}
$$

> Grande fala da Dita - tom: 'inevitabilidade' do sistema capitalista 
$\sigma$ importante, para Dita, é defender esse caminho aproveitar o 'cadáver' nos braços: mãe legista do fitho morto?

- Ordeme progresso - retoma as duas narradoras jogo de palarras com:

- a corda

- acorda

- acordo

- cordata

- cordados

'acabou' a ditadura, mas...

- Entrada da diagonal dabandeira
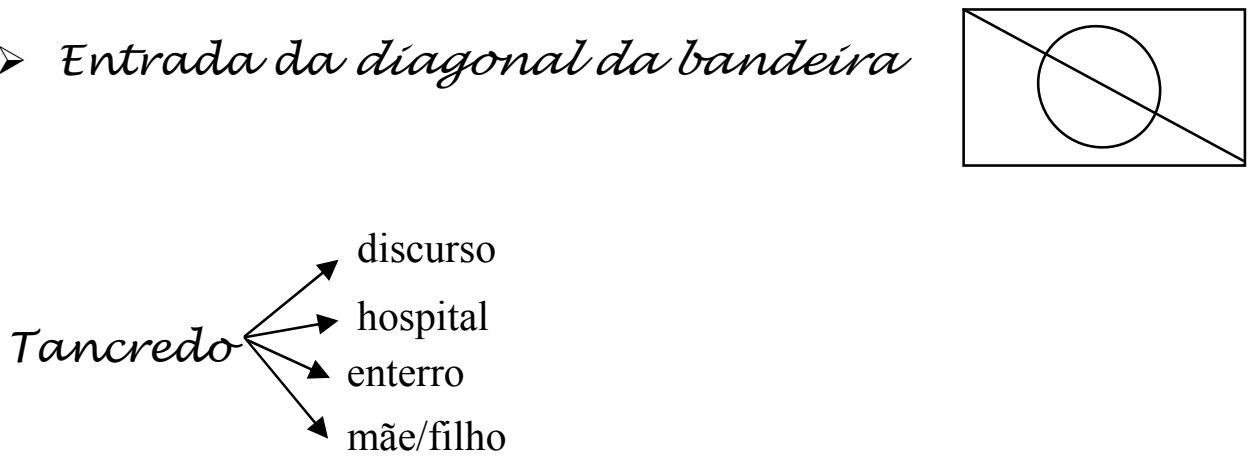

- discurso: é um novo día, não interessa o passado / certeza de que vai fazer a diferença

- hospital: 'deu merda'/ incerteza instaurada / ilusãorealidade

- enterro: efetivação da morte

- mãe/fitho: nulidade da oposição

09/02/2011

$>$ Seleção-tom: absurdo

clima: derrota

relação contraditória (derrota/vitória)

- Centro da 'bandeira': ordeme progresso Anjo da história

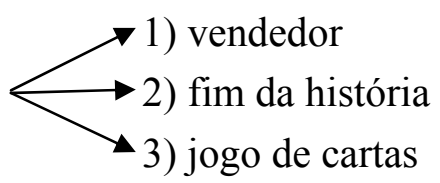


1) tom: feira

2) a história acabou $\sigma$ anjo - os dois othos da história: um otha o passado, outro ofuturo

$3^{\circ}$ tempo

$>$ indo para plateía - direitos de maiorias e minorias

> cena de violência - partitura física sem texto, projeção de texto de casos de violencia gratuita

tritha: gritos

- Lavaram a rua - tom: romântico das narradoras X reatidades de antes e de hoje

as coisas não são $\sigma$ que parecem, e acontecem em todo lugar

spots

$>$ Amanhece

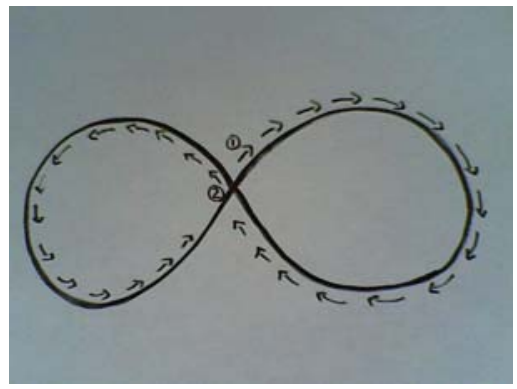

> Epúlogo-desabafo 


\section{NOS MEANDROS DA CRIAÇÃO ATORAL}

Sensação esquisita a de descrever exercícios. Tentativa imperfeita de narrar o que acontece num palco. As palavras não fazem justiça. Algumas coisas são mediocrizadas, outras não ficam claras.

Armando Sérgio da Silva ${ }^{130}$

A descrição de meu processo de criação na montagem do espetáculo Os filhos da Dita engloba - como toda criação artística - elementos de natureza objetiva e mais facilmente identificáveis e outros arraigados na subjetividade, mas que tento aqui acessar. $O$ foco principal está voltado à minha busca em utilizar procedimentos e/ou princípios da biomecânica de Meyerhold desde o momento de pensar a cena até sua concretização no palco, a relação com os demais atores (no início com Ana Maria Quintal, Bruno Garcia e Danielle Agostinho; posteriormente somente com Ana Maria Quintal), diretor (Sérgio Santiago), consultor musical (Gregory Slivar), preparadores corporais (Bruno Garcia e Yedda Carvalho Chaves - no treinamento de biomecânica) e, também, na aproximação ao tema tratado na peça: a ditadura civil militar brasileira instaurada entre 1964-1985 e seus reflexos até os dias atuais.

Faço minhas as palavras de Armando Sérgio da Silva que explicitam a dificuldade do ator em relação à formalização, pois, “[...] para nós, que trabalhamos com a prática, o exercício da escrita fica tão distante que frequentemente o adiamos." ${ }^{131}$ E complementa dizendo que "[...] o ato de criação implica sempre, em qualquer fase do processo, a obrigatoriedade de atos opcionais." 132

Algumas dessas opções é que serão aqui retratadas.

\footnotetext{
${ }^{130}$ SILVA, Armando Sérgio da. Oficina da essência. In: CEPECA: uma oficina de pesquisatores/ Armando Sérgio da Silva (organizador). São Paulo: Associação Amigos da Praça, 2010, p. 58.

${ }^{131}$ Ibidem, p.45.

${ }^{132}$ Ibidem, p. 50 .
} 


\subsection{PRINCÍPIOS E PROCEDIMENTOS DA BIOMECÂNICA UTILIZADOS NA CRIAÇÃO}

O contato com a biomecânica tem que se dar pelo corpo, tem que ser físico. É preciso experimentar as provocações, proposições. Como afirma Beatrice Picon-Vallin, “[...] é muito difícil compreender o que é a biomecânica por meio dos livros, mas os livros podem ajudar desde que se tenha compreendido alguma coisa com o corpo, como é com o corpo" (informação verbal). ${ }^{133}$

Durante o processo de montagem de Os filhos da Dita e desenvolvimento deste trabalho, pude vivenciar a prática da biomecânica de diversas formas, com distintos enfoques: junto aos demais membros do Arlequins em nosso processo de montagem, em disciplina ministrada por Yedda Carvalho Chaves no programa de pós-graduação da ECA/USP e como participante da oficina "Iniciação à biomecânica", durante o ECUM - Centro Internacional de Pesquisa Sobre a Formação em Artes Cênicas.
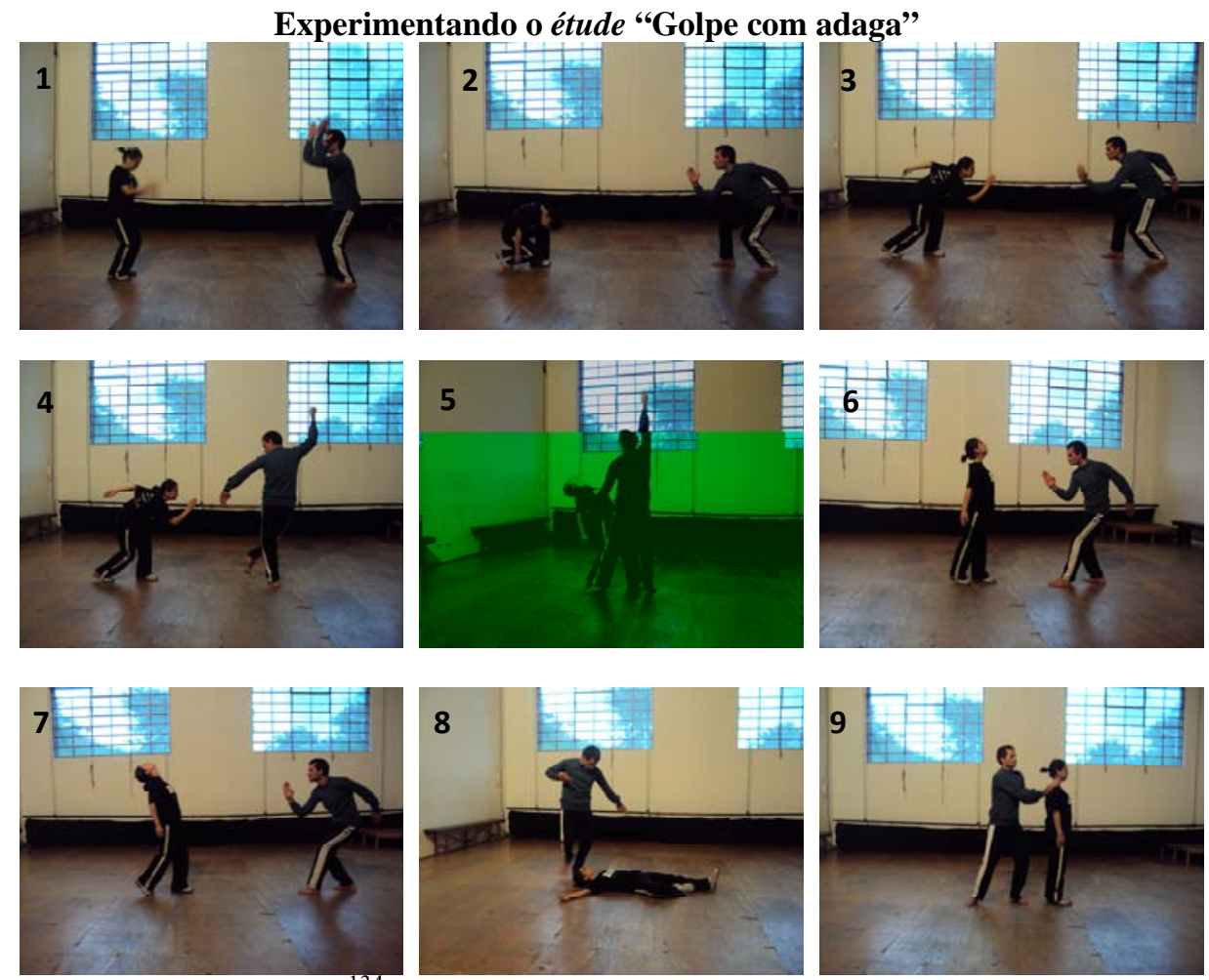

Sequência de fotos $3^{134}$ - Execução do étude "golpe com adaga" buscando compreender com o corpo as posturas, torções e tornar a repetição única, pessoal.

Nas fotos: Camila Scudeler e Renato Sérgio Sampaio (mestrando ECA/USP).

Período: maio/2010.

\footnotetext{
${ }^{133}$ Seminário sobre biomecânica ministrado por Béatrice Picon-Vallin durante ECUM, em 25 de outubro de 2010 .

${ }^{134}$ Disciplina da pós-graduação da ECA/USP intitulada "V. Meyerhold e o Ator do Futuro: Processos de Incorporação Vistos Pelas Neurociências", ministrada pela Prof ${ }^{a} \operatorname{Dr}^{a}$ Yedda Carvalho Chaves. ECA, maio de 2010.
} 
As distintas frentes de treinamento de biomecânica - no Arlequins, na disciplina da pós-graduação e do ECUM - foram complementares e de importância fundamental, embora a experiência durante o ECUM tenha me possibilitado trabalhar a poética proposta por Meyerhold em carga horária integral, durante 7 dias. A edição de 2010 do ECUM - Centro Internacional de Pesquisa Sobre a Formação em Artes Cênicas - ocorreu de 23 a 30 de outubro em Belo Horizonte/MG e teve como programa o Leste Europeu. A oficina intitulada "Iniciação à biomecânica", co-ministrada por Alexey Levinskiy ${ }^{135}$ (responsável pela prática) e Béatrice Picon-Vallin ${ }^{136}$ (que encarregou-se do embasamento teórico), tinha como objetivo estudar os elementos práticos da biomecânica e, paralelamente, trabalhar sobre as pesquisas de Meyerhold, sobre o movimento cênico e a biomecânica, por meio de textos, imagens e vídeos a fim de levar os atores participantes a sentir e a compreender como a biomecânica pode ajudar o ator a se perceber no tempo e no espaço cênico, ensinar o equilíbrio e a coordenação.

O ator e diretor russo Levinskiy, que aprendeu a biomecânica com Kustov (ator de Meyerhold), salientou durante os dias de intenso treinamento psicofísico, que, embora estivéssemos partindo de exercícios estruturados, marcados, o que deveríamos almejar era escutar o próprio corpo para que cada repetição servisse de caminho para desvendar nossas possibilidades e limitações individuais, para então podermos transpor tais barreiras. Muito além do que poderia ser considerado movimento mecânico, deve-se buscar, a partir da repetição, algo muito próprio, muito estimulante.

O trabalho prático com Levinskiy esteve calcado na exploração e ampliação da consciência rítmica (exercícios com os pés), prontidão e destreza (sequências com bastão), além do trabalho com o étude "Atirando a pedra". Reproduzo na sequência descrição de Robert Leach ${ }^{137}$ de exercícios de trabalho rítmico e com bastão ${ }^{138}$.

\footnotetext{
${ }^{135}$ Alexey Levinskiy é ator, diretor e professor. Laureado com o State Prize, graduou-se pela School-Studio of Moscow Art Theatre (MkhAT) em 1969. Nos anos 1970, foi um dos atores líderes do Satire Theatre, em Moscou. Começou a estudar a biomecânica com Nicolai Georgyevich Kustov, antigo colega de Meyerhold e professor de biomecânica na escola GosTIM nos anos 1930. Em 1979, Levinskiy se formou em direção teatral na The Russian Academy of Theatre Arts (GITIS). Atualmente, trabalha como ator e diretor nos teatros OKOLO e Ermolova, ambos em Moscou, e ministra master classes de biomecânica no The Meyerhold Centre (TMC), entre outros.

${ }^{136}$ Béatrice Picon-Vallin é pesquisadora, historiadora e teórica especialista em teatro russo e diretora do Laboratório de Pesquisas sobre as Artes do Espetáculo no Centro Nacional da Pesquisa Científica (CNRS). Doutora e professora em Estudos Teatrais e dirige um seminário de Diploma de Estudos Aprofundados (DEA) e Diploma de Estudos Superiores Especializados (DESS) sobre a encenação na Universidade Paris III (Sorbonne Nouvelle, Paris X - Nanterre), além de coordenar um programa de pesquisas sobre o teatro e as novas tecnologias. É ainda professora no Conservatório Nacional Superior de Artes Dramáticas (CNSAD) e em diversas escolas de teatro na França e Alemanha.

${ }^{137}$ LEACH, Robert. Stanislavsky and Meyerhold. Bern: Peter Lang, 2003.
} 
Trabalho rítmico com os pés - passos simples, colocação rítmica dos pés no chão (seguindo a ordem:), metatarso-calcanhar, metatarso-calcanhar, metatarso-calcanhar ou calcanharmetatarso, calcanhar-metatarso, calcanhar-metatarso, o grupo com cerca de trinta alunos deslocando-se juntas em círculo, para os lados, ou em direção ao centro. ${ }^{139} 140$

Trabalho com bastão - (pedaço de madeira de um metro de comprimento, ou cabo de vassoura, era usado para melhorar o senso de equilíbrio) equilíbrio na palma da mão, na testa, no ombro, no pé - e para ser jogado no ar e pego, jogado da mão esquerda para a direita, girando uma ou duas vezes no ar, jogado para o parceiro e assim por diante. [...] O trabalho com o bastão ensinava o ritmo básico da biomecânica, ou, inicialmente, métrica: "I-raz-dva '('E- um -dois'). Segure o bastão a cerca de um quarto de seu comprimento, dobre os joelhos e estique e, enquanto os joelhos são esticados, lançar o bastão levemente no ar, à medida que desce, deixe-o cair na palma da mão aberta, pegue-o." 141142

Todos os movimentos da biomecânica são divididos em três fases ${ }^{143}$ denominadas otkáz, possil, stoika, e referem-se, respectivamente, a: preparação da ação, a ação em si e suspensão da ação. Outro princípio fundamental é chamado raccourci. Apresento definição de otkáz e raccourci, uma vez que ambos serviram como norte para mim tanto na criação de cada fase das cenas como no meu pensamento sobre a peça como um todo (informação verbal) ${ }^{144}$ : - otkáz, em russo significa recusa. Trata-se de um movimento que vai em sentido inverso à direção do movimento principal. Pode-se encontrar o otkáz tanto na atuação como na composição cênica. No trabalho de ator, ele permite passar de um segmento de ação a outro, e o serve de "trampolim", o elo entre os movimentos. É importante a imagem do trampolim

\footnotetext{
${ }^{138}$ Optei pro reproduzir o texto de Leach, que descreve detalhes da estrutura dos exercícios ensinados pelos professores de biomecânica do Teatro de Meyerhold (o treinamento geralmente ocorria no GITIS ou no Zon Theatre), uma vez que são estes mesmos exercícios trabalhados por Levinskiy na oficina do ECUM. Estes exercícios estiveram na base de minha criação em vários aspectos: primeiramente por aguçarem o senso rítmico (base de qualquer movimentação cênica), e por desenvolverem o senso de equilíbrio, destreza, direção, concentração e jogo.

${ }^{139}$ LEACH, Robert. Stanislavsky and Meyerhold. Bern: Peter Lang, 2003, p. 153.

${ }^{140}$ Footwork - simple steps, as the rhythmic placing of the foot on the ground, toe-heel, toe-heel, toe-heel, or heel-toe, heel-toe, heel-toe, the group of up to thirty students moving together in a circle, sideways, or towards the centre.

${ }^{141}$ Ibidem, p. 153.

${ }^{142}$ Stick work, in which a meter long piece of dowel, or broom handle, was used to improve the sense of balance - balance it on the palm of the hand, the forehead, the shoulder, the foot - and to be tossed in the air and caught, tossed from left hand to right hand, spun once or twice in the air, tossed to the partner and so on. [...] The work with the stick taught the basic Biomechanics rhythm, or, initially, meter: 'I-raz-dva' ('And-one-two'). Hold the stick about a quarter of the way up its length, bend the knees and straighten, and as the knees straighten, lightly toss the stick in the air; as it descends, let it fall into the open palm, catch it.

${ }^{143}$ Conforme mencionado no capítulo 2 deste trabalho.

${ }^{144}$ As definições apresentadas são provenientes de anotações e transcrição das falas de Béatrice Picon-Vallin em seminário sobre biomecânica durante o ECUM (outubro 2010).
} 
para se compreender realmente a função do otkáz, que serve ainda como um sinal para o parceiro.

- raccourci é uma perspectiva sobre um objeto, uma pessoa (um corpo), visto de um ponto de vista não ordinário, não cotidiano, não habitual: a partir de baixo, de cima, de lado. A busca por essa perspectiva é perceptível nos exercícios de biomecânica uma vez que estes são compostos por movimentos que privilegiam torções e ângulos que não são vistos cotidianamente.

A utilização de treinamento no processo criativo tem como estrutura gerar e criar um território onde se buscam experiências. Não se trata somente de levar o corpo ao limite, mas deixar que a ação seja pensamento, ou melhor, que o pensamento seja guiado pelo corpo e, dessa maneira, as decisões são tomadas a partir das relações corporais que se estabelecem. A biomecânica vai dar ao ator a capacidade de criar movimentos inéditos e não cotidianos, já que, para Meyerhold, o teatro não é a reprodução do cotidiano.

Matteo Bonffitto, no livro $\mathbf{O}$ ator-compositor, salienta que as chamadas bases $d a$ biomecânica são “[...] um treinamento global 'que envolve o cérebro e o corpo' do ator; e que têm como cerne do sistema a 'pesquisa sobre as diferentes possibilidades de relação entre movimento e palavra; e a importância do ritmo." ${ }^{145}$ E continua:

Mesmo não sendo um 'sistema de interpretação', o sistema biomecânico envolve o inteiro processo criativo do ator. Uma característica de tal sistema é que ele, segundo Meyerhold, deveria desenvolver-se inteiramente na esfera do consciente. 'O inteiro sistema biomecânico, o inteiro processo de nossos movimentos, é ditado por um princípio fundamental: o pensamento, o cérebro humano, o aparato intelectivo. Esta é a coluna portante do inteiro sistema biomecânico'. (Meyerhold apud BONFFITTO) O objetivo de tal princípio era o de levar o ator, dessa forma, a aprender a controlar os próprios meios expressivos independentemente das condições do momento. A biomecânica coloca em relevo a compreensão, por parte do ator, de sua atividade psicofísica durante seu processo criativo. ${ }^{146}$

Para concluir este sub-capítulo é importante salientar que - assim como para Meyerhold, o objetivo na relação com a commedia dell'arte (uma das maiores inspirações de seu trabalho) não era chegar até ela, mas partir dela - também me proponho a trabalhar com a biomecânica desta maneira: como ponto de partida.

\footnotetext{
${ }^{145}$ BONFFITTO, Matteo. O ator-compositor - as ações físicas como eixo: de Stanislávski a Barba. São Paulo: Perspectiva, 2002, p. 43.

${ }^{146}$ Ibidem, p. 44.
} 


\section{Registro ECUM}

\section{Étude "Arremesso da pedra"}
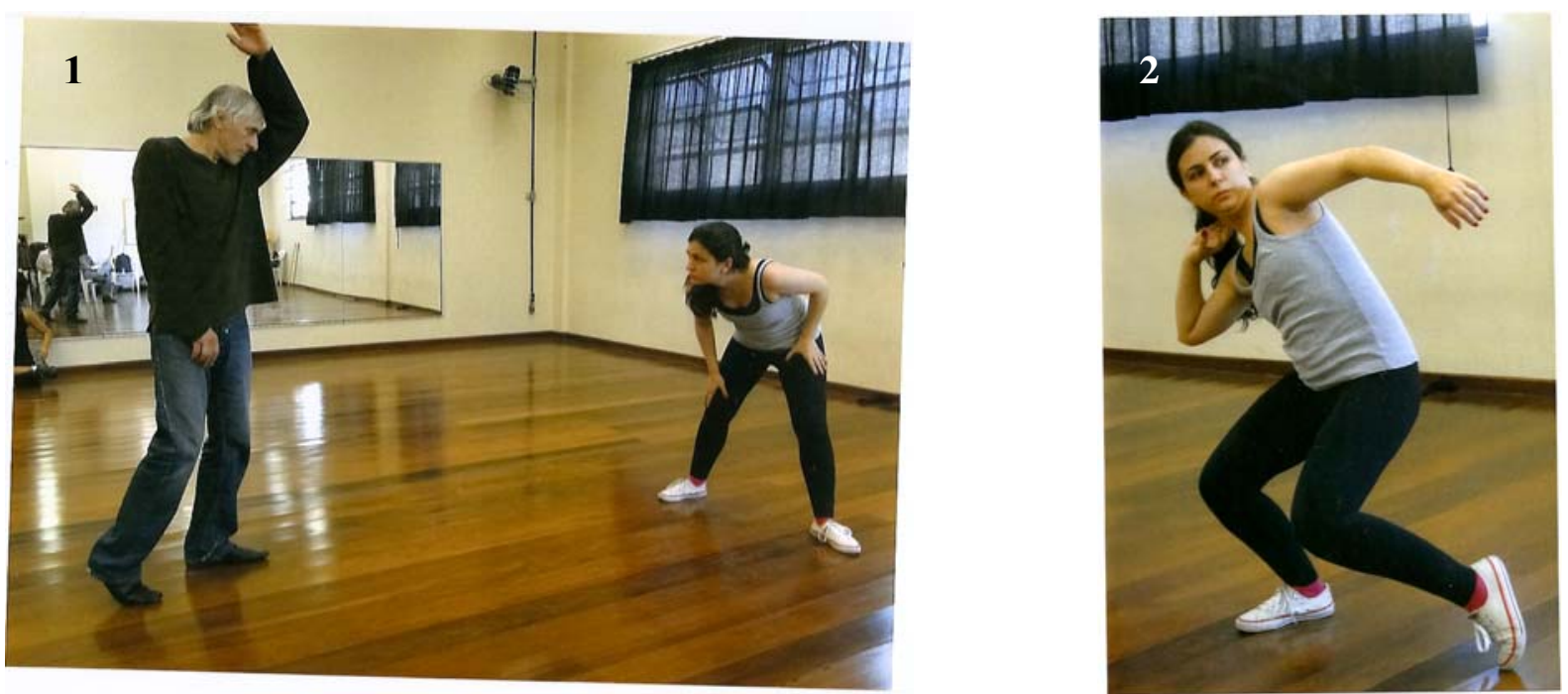

Sequência de fotos 4: foto número 1 - recebendo instrução de Alexey Levinskiy foto número 2 - executando trecho do étude "Arremesso da pedra"

Período: outubro/2010.

Crédito: Gustavo Côrtes

Trabalho com bastão
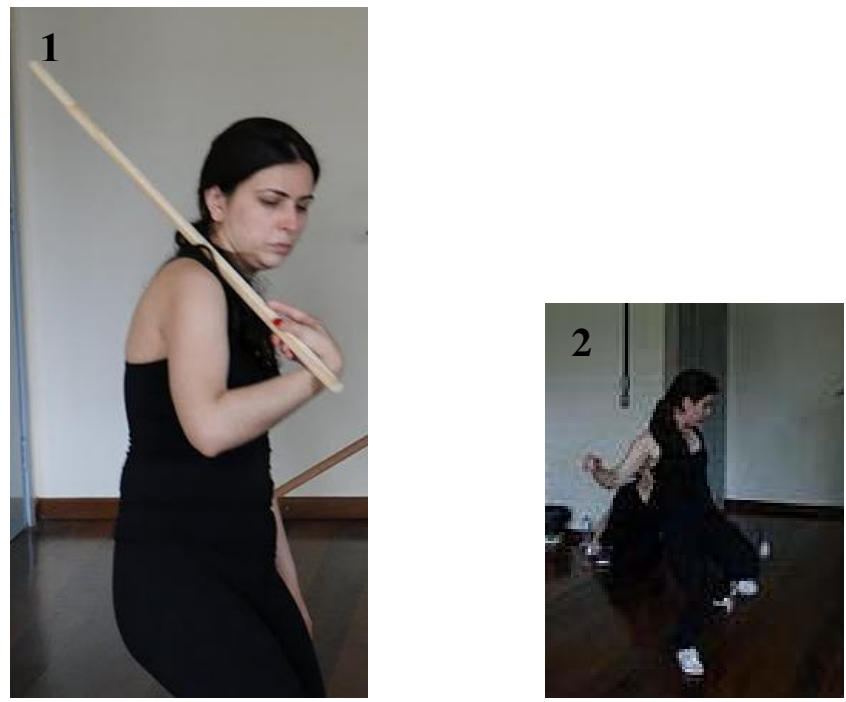

Sequência de fotos 5: foto número 1 - deslizando o bastão pelo ombro

foto número 2 - equilibrando bastão com o lado externo do pé esquerdo

Período: outubro/2010.

Crédito: Gustavo Côrtes 


\subsection{CRIAÇÃO DE CENAS DE Os filhos da Dita}

As cenas aqui descritas estão agrupadas em dois blocos: aquelas nas quais a criação se deu individualmente, e aquelas em que a criação se deu a partir das relações com os demais atores - nas diferentes fases do processo.

O espetáculo tem como essência de linguagem a fragmentação, o que possibilitou ao grupo optar por retratar distintos aspectos da ditadura. ${ }^{147}$ Dado o caráter deste trabalho, foram escolhidas algumas cenas para serem aqui descritas, cujo critério principal de seleção foi o diálogo da criação com a biomecânica, cenas criadas individualmente por mim e ressonância com outros espetáculos do grupo (que servem para consolidar características da linguagem desenvolvida). Outras cenas aparecem por meio de registro fotográfico.

\subsubsection{CRIAÇÃO INDIVIDUAL}

$\mathrm{O}$ ator meyerholdiano mantém certo afastamento do papel. Ele nunca usa sua própria experiência emocional para construir sua performance. De fato, deliciar-se com sua própria habilidade pode ser contrastado deliberadamente com a emoção de sua personagem para fornecer um determinado tipo de tensão - e prazer - para os espectadores.

Robert Leach 148149

Meu processo de criação sempre ocorre a partir do corpo - minha 'manivela ativadora' de ideias e sentimentos é o movimento. Com raízes na graduação em Artes Cênicas, quando trabalhávamos prioritariamente explorando as capacidades de expressão do corpo e a partir da desconstrução do sentido, da fala, da gestualidade cotidiana, meu corpo ampliou sua capacidade de pensar - inerente a todo ser humano. Meu corpo pensa cenicamente primeiro e, somente numa segunda fase, consigo fazer as correlações que se dão à medida que se faz necessária a organização de sentidos.

Na criação de Os filhos da Dita esteve sempre latente em mim todo o material teórico que vinha estudando e sua concretização em cena se deu a partir dos espaços que meu corpo ocupava na sala de ensaio e no palco. Tal procedimento pode dar a impressão de que acontece somente num nível subjetivo, mas não é. Tampouco se trata de "livre expressão corporal". É,

\footnotetext{
${ }^{147} \mathrm{O}$ espetáculo é composto por cerca de 30 cenas.

${ }^{148}$ LEACH, Robert. Stanislavsky and Meyerhold. Bern: Peter Lang, 2003, p. 110.

149 The Meyerholdian actor keeps his distance from the role. He never uses his own emotional experience to construct his performance. Indeed, delight in his own skill may be deliberately contrasted with his character's emotion to provide a particular kind of tension - and pleasure - for the audience.
} 
na realidade, a expressão do corpo que ocorre em velocidade superior à compreensão e organização intelectual. Como sublinha Yedda Carvalho Chaves, ao analisar a obra de William James e como essa influenciou o trabalho de Meyerhold, o corpo tem a capacidade de pensar antes (informação verbal). ${ }^{150}$

IARA

Personagem que perpassa o espetáculo, aparecendo em diversos momentos dentro da estrutura fragmentada do espetáculo, é a referência àqueles que resistiram aos desmandos da ditadura.

\section{Como encontrar Iara?}

A aproximação à personagem se deu a partir de distintos estímulos. Um deles foi a biografia de Iara Iavelberg ${ }^{151}$, que serviu como menção e poesia para essa personagem à qual emprestou seu nome e a força de sua luta - fica registrada nossa homenagem.

Mas, como encontrá-la?

[...] para o ator, num primeiro momento, a personagem não existe, pelo menos, como um objeto sensível e identificável. O estímulo inicial, aquilo que chama a atenção do ator, é uma espécie de dado incompleto, um quebracabeça, um jogo que ele pretende completar. Se esse estímulo, por exemplo, é uma foto, falta, em primeiro lugar, o movimento que é ligado ao sentido do tato, depois o ritmo, as palavras etc. Se o estímulo é uma música, falta a iconografia, que é ligada ao sentido da visão, as palavras, o jogo dramático etc. Se for uma narrativa literária faltam, em primeiro lugar, as configurações das ações dramáticas. Em resumo, quaisquer que sejam os dados ausentes, a operação que se exige, sempre, é a da imaginação criadora. $^{152}$

Uma vez que a personagem aparece em distintas cenas - em meio à fragmentação - busquei utilizar um objeto que remetesse à personagem e pudesse ser percebido pelos

\footnotetext{
${ }^{150}$ Anotações feitas durante aula da disciplina "V. Meyerhold e o ator do futuro: processos de incorporação vistos pelas neurociências" ministrada pela Prof ${ }^{\mathrm{a}}$. Dra. Yedda Chaves de Carvalho no programa de pósgraduação da ECA/USP, no dia 18 de março de 2010.

${ }^{151}$ PATARRA, Judith Lieblich. Iara: reportagem biográfica. Rio de Janeiro: Rosa dos Tempos, 1992.

Iara Iavelberg (1944 - 1971) foi uma militante e guerrilheira, integrante da luta armada contra a ditadura militar brasileira. Psicóloga e professora, depois de entrar na luta contra o regime militar, primeiro integrando a Organização Revolucionária Marxista Política Operária (Polop) e depois o Movimento Revolucionário 8 de Outubro (MR-8), tornou-se companheira do ex-capitão do exército Carlos Lamarca, um dos principais líderes da oposição armada ao governo militar no Brasil, até morrer num cerco de agentes de segurança em Salvador, Bahia, em agosto de 1971.

152 SILVA, Armando Sérgio da. Oficina da essência. In: CEPECA: uma oficina de pesquisatores. Armando Sérgio da Silva (organizador). São Paulo: Associação Amigos da Praça, 2010, p. 52.
} 
espectadores mais atentos: a escolha foi um bracelete preto e vermelho, feito de zíperes e elástico (objeto sugerido pelo figurinista, Eder Lopes).

Sua trajetória: já na cena inicial podemos vê-la no pau de $\operatorname{arara}^{153}$ estilizado. Depois aparece em cena com mais ação na qual o jogo de luzes dá a dimensão de uma tentativa de fuga frustrada que resulta em prisão - a partir deste momento aparecem na personagem o desespero e as mazelas de uma presa política em uma cela após série de seções de torturas (que nunca são mostradas em cena, são no máximo mencionadas em suas falas ${ }^{154}$ ). e sua próxima aparição trata da Iara já presa... Silva ressalta que “[...] o conhecimento da personagem, obrigatoriamente, se dá através do corpo e este possui memória própria e diferenciada." 155

$\mathrm{Na}$ construção de uma das cenas em que aparece Iara, a dificuldade estava me consumindo... Texto denso... E a cena não surgia... Foi então que decidi partir do bastão, busquei na relação com esse objeto e em algumas sequências aprendidas (durante o ECUM) o suporte para aproximar-me do texto com o qual vinha tendo dificuldades. Em princípio a ideia foi "preencher" aquele espaço, "marcar território" e não deixar que aquele momento, aquele lugar fossem engolidos por outras cenas - fim comum para cenas que não resultam... Queria poder testar mais, experimentar novas possibilidades... Em princípio serviu somente para isso: a partir da execução de movimentos já dominados, minha mente estava livre para poder brincar com o texto, testar distintas maneiras de enunciá-lo, buscar possibilidades.

O bastão tradicional - em geral de madeira, com espessura semelhante a de cabo de vassoura e 1 (um) metro de comprimento - devido à sua leveza, foi trocado por um bastão já usado em outras cenas do espetáculo - mais espesso e longo. A relação que buscamos estabelecer com os objetos no Arlequins está calcada na múltipla possibilidade de significações que um objeto pode ter - e a utilização deste bastão ocorre dentro do mesmo princípio: o objeto torna-se "coringa" e compõe com outros objetos que também têm sua significação reinventada a cada cena. Para exemplificar como isso ocorre com o bastão: aparece como um fuzil do cabo (soldado) na cena inicial (“Canção do expedicionário"), pau

\footnotetext{
${ }^{153}$ Termo usado também para designar caminhões adaptados para o transporte de passageiros, muitas vezes usado para levar migrantes nordestinos para o sudeste do Brasil, aqui se refere a uma técnica de tortura amplamente empregada durante a ditadura civil-militar brasileira. Consiste em uma barra de ferro que é atravessada entre os punhos amarrados e a dobra do joelho, sendo o conjunto colocado entre duas mesas. Este método quase nunca é utilizado isoladamente, seus complementos mais frequentes são eletrochoques, a palmatória e o afogamento.

${ }^{154}$ A opção de não colocar a tortura em cena foi tomada no início da pesquisa. Parte-se do pressuposto de que é algo tão terrível que nenhuma representação cênica atingiria o grau de atrocidade cometida, então melhor seria registrar sua existência por meio de textos, menções, sugestões...

${ }^{155}$ SILVA, Armando Sérgio da. Oficina da essência. In: CEPECA: uma oficina de pesquisatores. Armando Sérgio da Silva (organizador). São Paulo: Associação Amigos da Praça, 2010, p. 82.
} 
de arara estilizado, barreira (delimitação de espaço), é utilizado recorrentemente para compor cenas de espancamento (sugerindo pauladas) e ainda como arma de treinamento nas mãos de uma militante revolucionária que participa da luta armada (Iara).

Voltando às dificuldades que encontrei na construção da cena: uma vez que, em princípio o bastão foi simplesmente colocado (quase que forçosamente), aquela movimentação começou a ficar demasiadamente marcada, remetendo ao marcial, lhe faltava função, motivação real, necessidade de estar ali para que não fosse apenas "decorativo"... Num ensaio, Sérgio Santiago pediu que eu compartimentasse o movimento, explicitando o momento em que eu gostaria de sugerir que Iara apanhava. Aquilo me soou muito estranho porque, para mim desde o início, era a Iara quem batia e quem apanhava. Era ela em seu treinamento de guerrilha e sendo capturada. Como muito disso estava só em minha cabeça, o fato de ser meu subtexto não garantiu que conseguisse expressar essas nuances. Sérgio entendeu o que eu queria dizer, levou para sua casa a câmera de vídeo que havia registrado todo o ensaio - inclusive meu momento de 'defesa' da personagem, aquele no qual eu explicitava minhas intenções (para mim claras e óbvias), momento da atriz argumentando a fim de aproximar-se da personagem. Sérgio transcreveu as falas e, mais importante, as pausas que utilizei naquele momento em que busquei articular e organizar o conteúdo. No ensaio seguinte ele propôs compartimentar a movimentação e incluir, naquela dinâmica, o processo de aproximação da atriz à personagem, e meu texto que agora seria levado à cena. Com a nova estrutura, a cena passou a sintetizar uma das pesquisas mais arraigadas do Arlequins conter o cerne da pesquisa ter: deslizamento do discurso direto/indireto/direto. ${ }^{156}$

\begin{tabular}{|c|c|c|}
\hline 1. Iara & $\begin{array}{c}\text { 2. atriz / personagem } \\
\text { (narradora/Iara) }\end{array}$ & 3. Iara \\
\hline
\end{tabular}

\footnotetext{
${ }^{156}$ Para maior compreensão desta descrição ver texto completo da cena na página 98 (Anexo B).
} 


\section{Menção estilizada ao pau de arara}
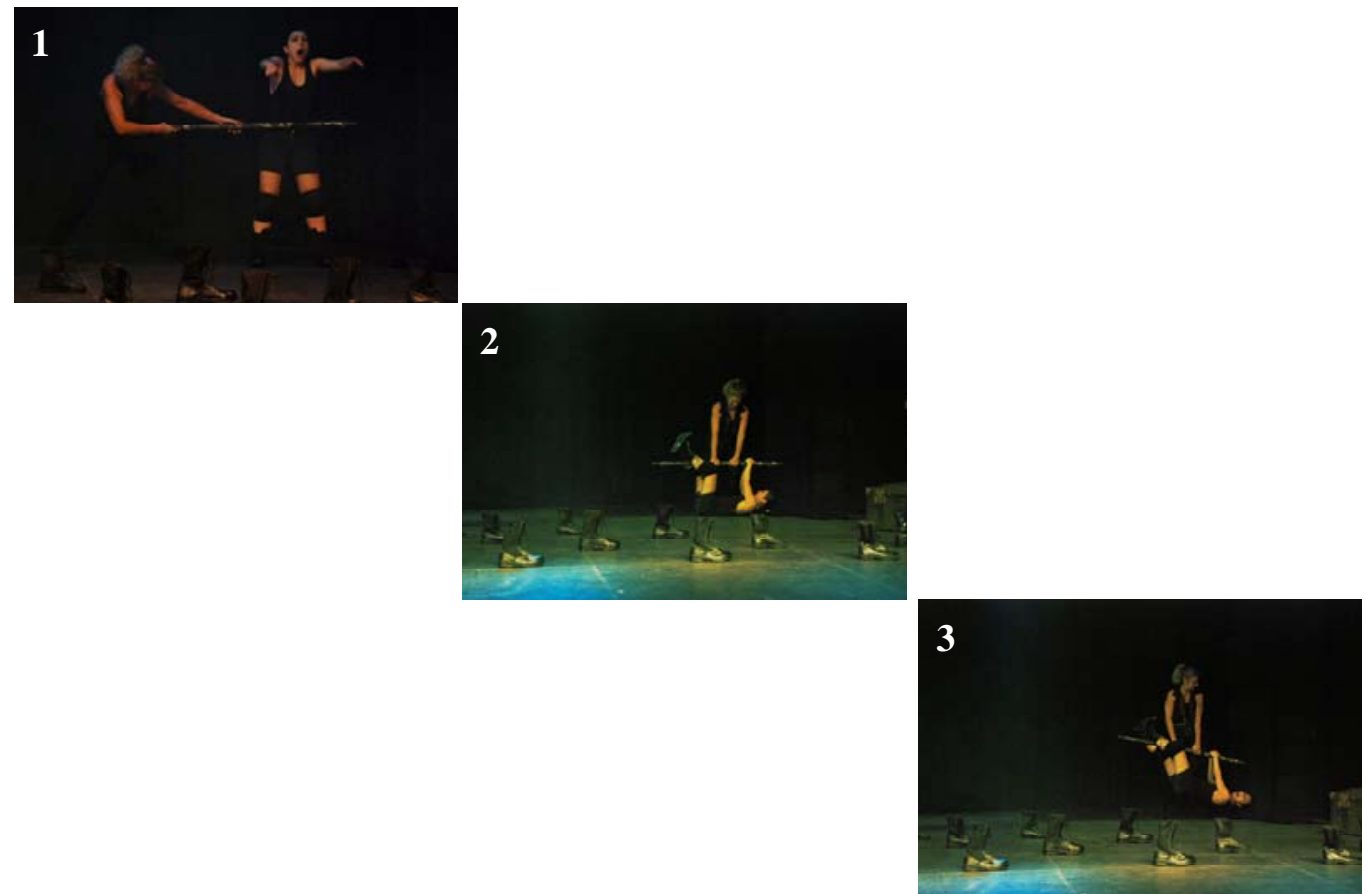

Sequência de fotos 6: foto número 1 - apanhando com o bastão fotos números 2 e 3 - sendo colocada e levantada no pau de arara

Nas fotos: Camila Scudeler e Ana Maria Quintal

Período: maio/2010.

Local: Teatro Coletivo / São Paulo

Crédito: Marisa Quintal

\section{Iara em fuga}
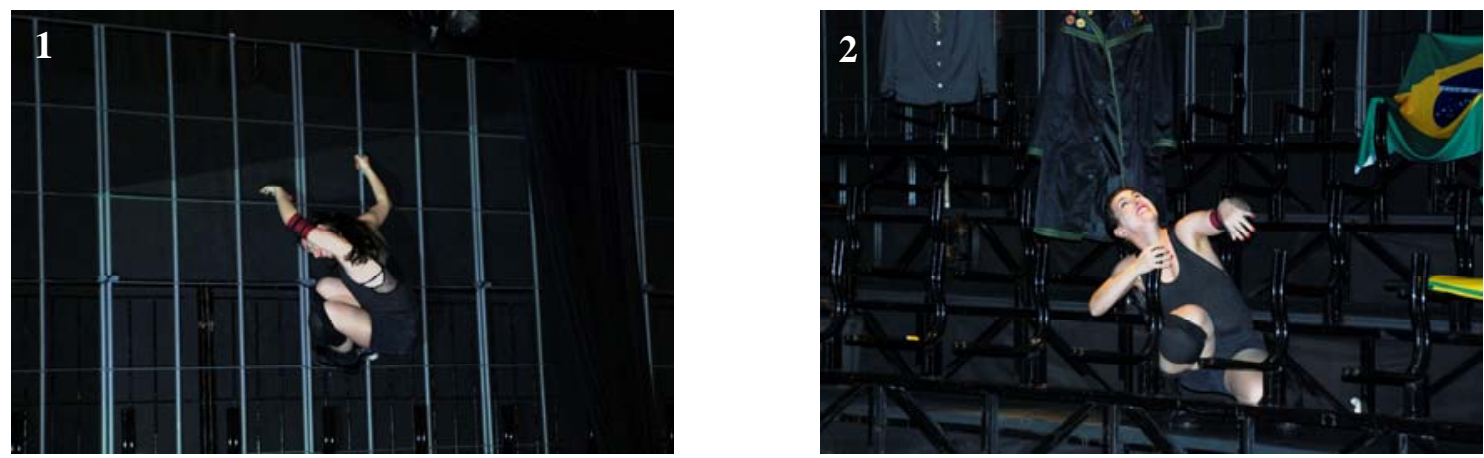

Observação: as cenas de fuga da Iara, embora tenham uma marcação espacial geral no palco (inicio do lado esquerdo e posteriormente corro para o lado direito, bem próxima ao proscênio), são exploradas as possibilidades que cada espaço de apresentação oferece. As fotos aqui reproduzidas foram são de apresentação realizada no Engenho Teatral: à esquerda havia grades (utilizadas no espetáculo daquele grupo) - nas quais subi, e à direita, estruturas de cadeiras (que tiveram sua função alterada, já que optamos por manter público somente à frente) que serviram como suporte de objetos que remetem aos militares (vistos ao fundo) e também exploradas como espaço de fuga, enquanto a personagem era perseguida por helicópteros.

Sequência de fotos 7: foto número 1 - em fuga subindo pelas estruturas do teatro

Período: agosto/2010. foto número 2 - sendo perseguida por helicópteros (ouve-se o som)

Local: Engenho Teatral / São Paulo

Crédito: Marisa Quintal 


\section{Cena de Iara criada a partir da relação com o bastão}
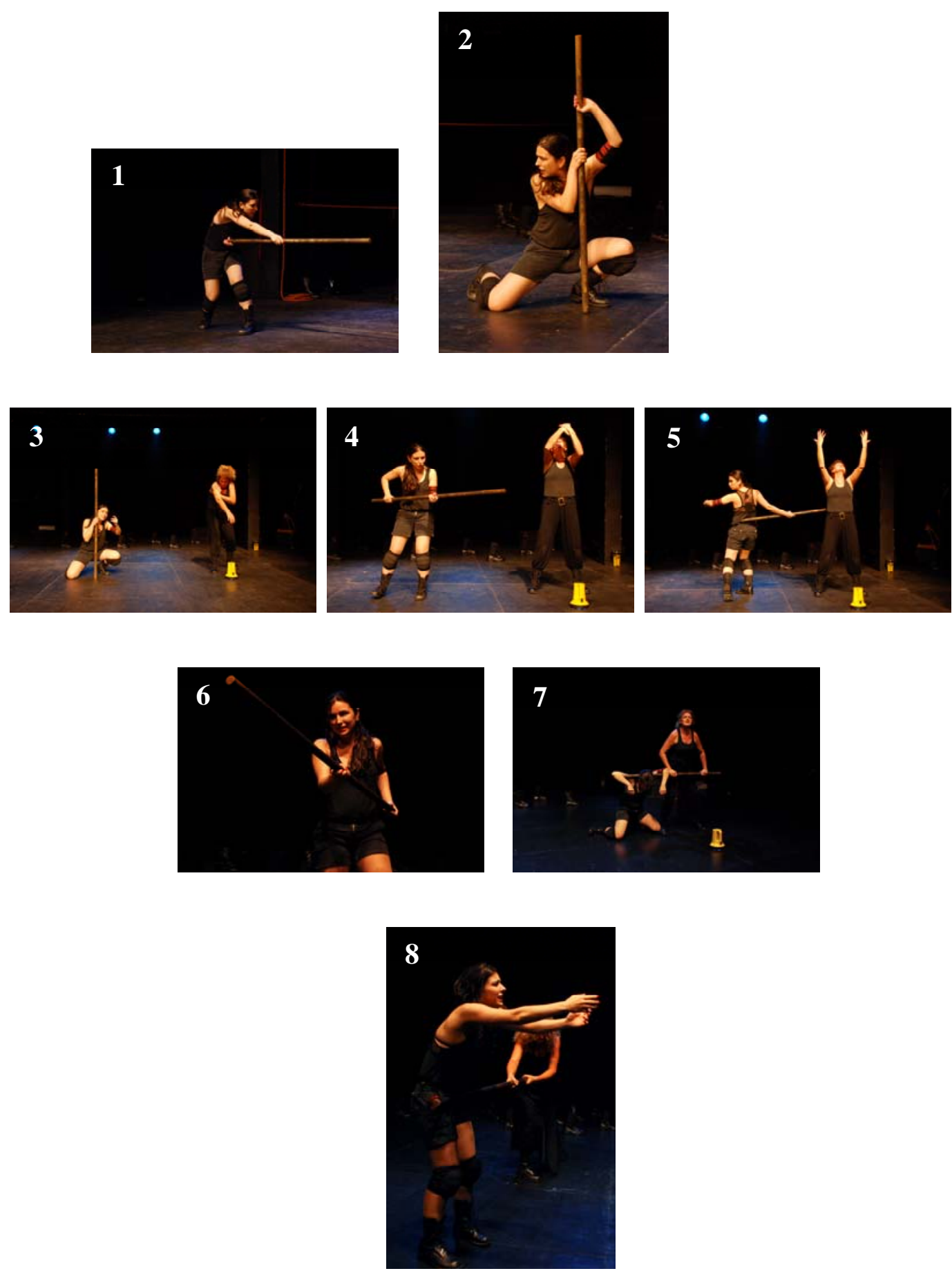

Sequência de fotos 8: as fotos acima apresentam os diferentes momentos da personagem: manejando o bastão em treinamento (fotos 1 e 2), momento de deslizamento para narradora que descreve a situação na qual se encontra a personagem (foto 3), e novamente a personagem recordando-se de fases de sua vida e vivenciando situações de tortura (levando paulada) (fotos 4,5,6,7 e 8).

Nas fotos: Camila Scudeler e Ana Maria Quintal

Período: maio/2010.

Local: Teatro Coletivo / São Paulo

Crédito: Marisa Quintal 
Em fevereiro de 2011, durante recesso de 15 dias do Arlequins, decidi participar de workshop sobre a técnica de representação desenvolvida por Michael Chekhov ${ }^{157}$. Buscava encontrar ali alguns subsídios complementares que me ajudassem a desenhar as nuances de Iara... Foram apenas 3 dias, mas que se mostraram instigantes. Das vezes em que tinha lido Para o ator, livro escrito pelo ator sobrinho do dramaturgo Anton Chekhov, senti que os exercícios ali descritos me soavam paradoxalmente compreensíveis e desinteressantes - tinha a impressão de não haver ali centelha nova, estimulante. Lia e remetia aqueles aos exercícios feitos tantas vezes na escola de teatro, diversas oficinas... Provavelmente seja mesmo tirado dali muito do que se apresenta aos iniciantes, e que haviam sido importantes quando eu dava meus primeiros passos nesse universo, mas já não me estimulavam mais.... No entanto, a abordagem proposta por Hugo Moss trouxe colorido mais intenso. E reler o material após vivência desde essa nova perspectiva passou a ser mais instigante.

E foi a partir do primeiro exercício descrito no livro, que sugere ao ator que se feche

[...] cruzando os braços sobre o peito e colocando as mãos nos ombros. Ajoelhe-se em um ou ambos os joelhos, inclinando a cabeça para frente e para baixo. Imagine que está ficando cada vez mais pequenininho, enroscando-se, contraindo-se como se quisesse desaparecer corporalmente dentro de si mesmo e como se o espaço à sua volta estivesse encolhendo ${ }^{158}$. 159

Daí defini e experimentei a sensação que queria imprimir à cenas de Iara presa relação direta com o exercício, sem muitas nuances criativas em princípio... Foi a partir dessa definição que delimitei, inclusive espacialmente, a exploração da movimentação que estava criando. Para deixar mais claro no que tais escolhas resultaram (a primeira vez em que Iara se apresenta com texto ${ }^{160}$ e inclusive relata seus dias de tortura), optei por restringir o espaço de movimentação ao da superfície de uma folha de zinco - para apresentações em escolas e demais espaços alternativos - e a um pequeno praticável de madeira posto próximo a um baú. Em ambos os casos a movimentação é a mesma: no plano baixo, raivosa, mordida, - rente ao chão e girando em círculos remete à movimentação de um cão ao redor de si mesmo. Uma raiva que corrói Iara e a coloca próxima a um sentido mais ancestral... O final do texto

\footnotetext{
157 O workshop "Qualidades do gesto: o universo de Michael Chekhov" foi ministrado por Hugo Moss no Centro Cultural b_arco, na cidade de São Paulo, nos dias 15, 16 e 17 de fevereiro de 2011, com carga de $10,5 \mathrm{~h}$.

${ }^{158}$ Grifo nosso.

${ }^{159}$ CHEKHOV, Michael. Para o ator. São Paulo: Martins Fontes, 1996, p. 7.

${ }^{160}$ Ver texto completo da cena na página 95 (Anexo B).
} 
antecipa cena que só ocorrerá bem mais adiante: “crio sombras e me relaciono com elas... eu mesma, nem sei..." 161 - remete à criação da "Dita".

Em outro fragmento, Iara aparece no plano baixo, enlouquecendo em cela solitária e corroída pela tristeza. A movimentação é visceral, num processo que remete à invocação de deuses. Uma Medeia transtornada, buscando energia da terra, sentencia:

Você é real porque minha vontade quer. Mesmo aqui, lambendo feridas que não querem cicatrizar, não quero as faces animalescas dos que nos torturam... De animais andamos fartos! A humana, a mais dignamente humana face: coloca! Coloca e vem me dizer. Vem! Do inferno que te pariu, vem! Porque eu preciso... Eu preciso falar com alguém... Já que mataram meus amigos, vem inimigo, vem! E me diz o nome maldito da sua razão! Vem e me diz o que é que te fez! ${ }^{162}$

É criada a "Dita". Uma relação ambígua e desigual se estabelece entre as duas personagens e "[...] a nossa Dita, que não hesitou em matar seus filhos, só lamenta que os MORTOS (do passado e do futuro: estes não perdem por esperar) não tenham entendido sua lição de AMOR, empenhada a ponto de usar todas as armas disponíveis, inclusive a tortura, para demonstrá-la". 163

\footnotetext{
${ }^{161}$ MIRANDA, Éjo da Rocha; QUINTAL, Ana Maria. Os filhos da Dita. São Paulo, 2011. (Anexo B)

${ }^{162}$ Ver texto completo da cena na página 104 (Anexo B).

163 COSTA, Iná Camargo. Filhos da indigna Dita. Crítica à peça publicada na página da internet http://geracaoai5.blogspot.com/p/filmes-que-temos-visto.html.
} 


\section{Primeira aparição de Iara na solitária}
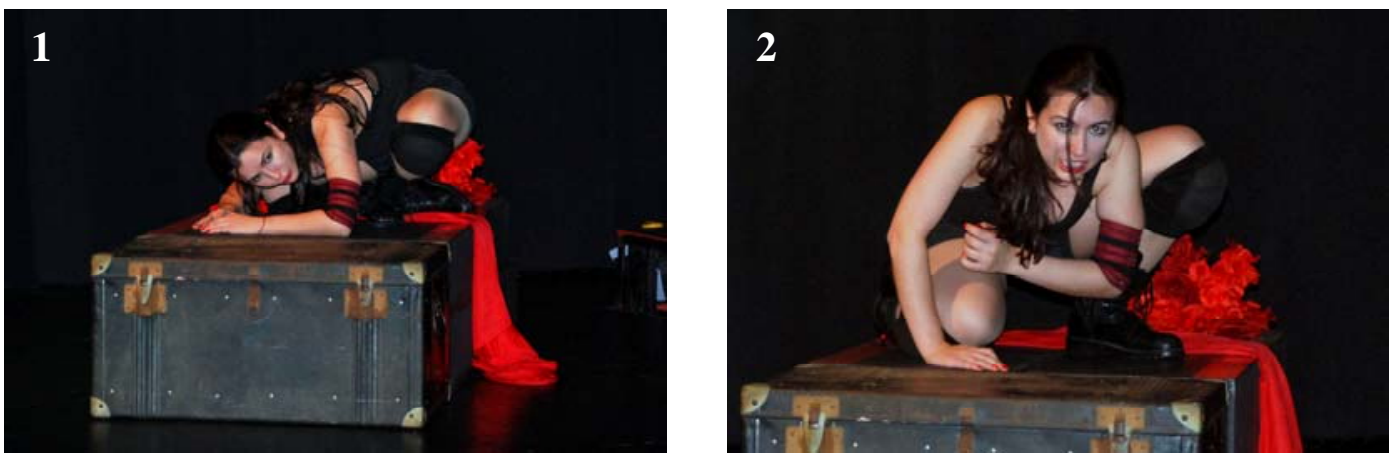

Sequência de fotos 9: as fotos acima retratam o momento em que Iara desabafa acerca de sua dor, física e emocional após tortura a que foi submetida e declara criar "sombras", por estar isolada, na solitária.

Período: maio/2010.

Local: Teatro Coletivo / São Paulo

Crédito: Marisa Quintal

\section{Desabafo na solitária e criação da Dita}
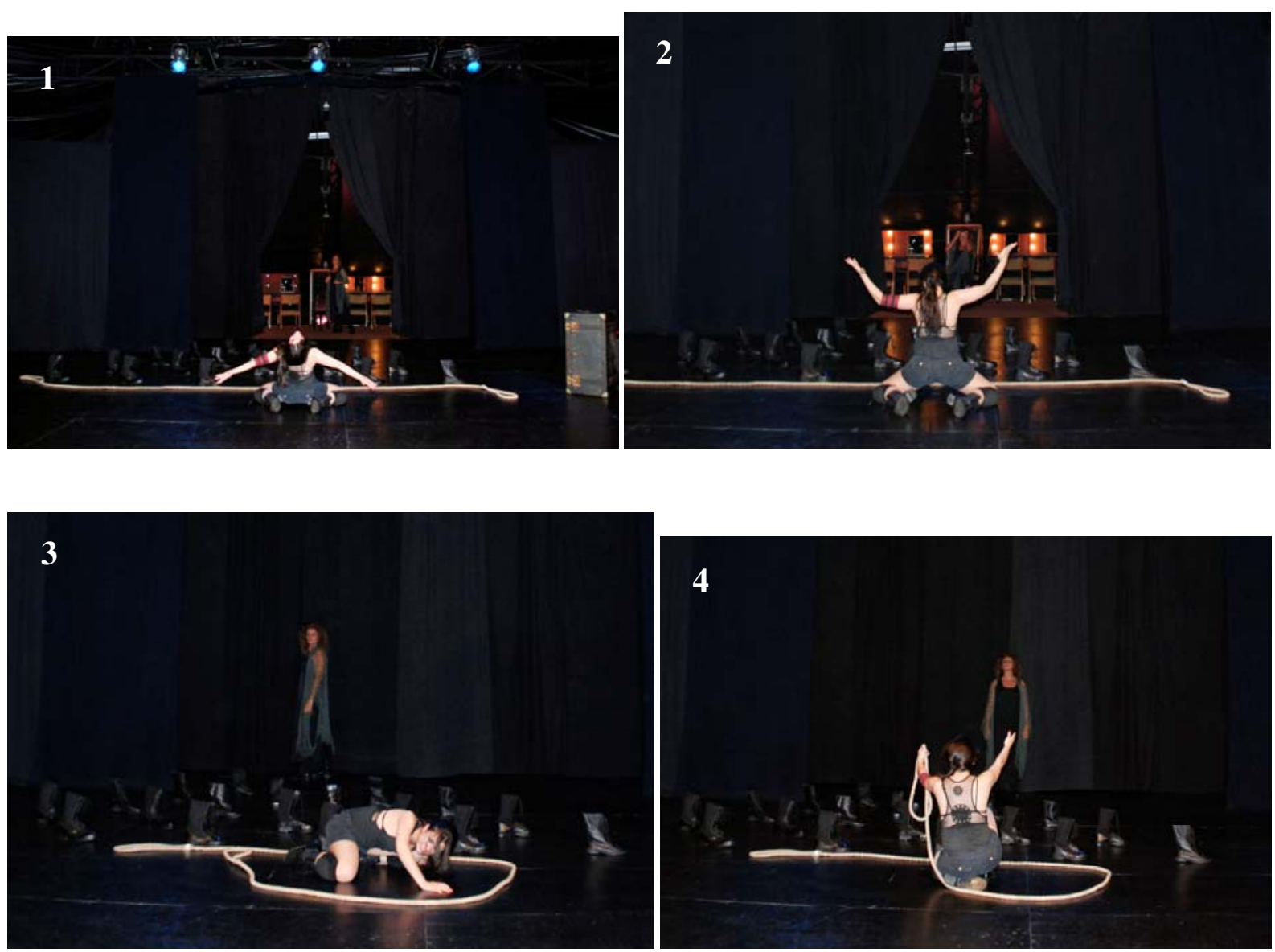

Sequência de fotos 10: as fotos apresentam Iara desabafando e criando a Dita (fotos 1 e 2 a Dita aparece ao fundo e refletida no espelho, já em 3 e 4 se aproxima de Iara).

Nas fotos: Camila Scudeler e Ana Maria Quintal

Período: maio/2010.

Local: Teatro Coletivo / São Paulo

Crédito: Marisa Quintal 
O mesmo exercício proposto por Hugo Moss ${ }^{164}$, a partir das indicações de Michael Chekhov, foi utilizado para criar outra cena da personagem Iara em que esta se encontra numa solitária, partindo principalmente da 'sensação de estar sendo tragada pelo entorno'. Seguia a opção por criar a partir de um espaço físico limitado e demarcado no palco - neste caso uma das faces do baú de metal. Após inúmeros jogos em que me propus explorar o objeto, sustentar-me no alto do baú posicionado na vertical foi o modo escolhido para compor esse momento, alterando inclusive a utilização corriqueira deste objeto. Embora em cima do baú, a movimentação tem início no plano baixo (em relação à superfície do objeto) e conforme o grau de divagação apresentado pelo texto ganha consistência, também passa a existir espaço para a expansão física - outra vertente do mesmo exercício proposto por Chekhov: "Abra-se 165 completamente, escancarando os braços e espalmando as mãos como se estivesse abrindo as asas para alçar vôo, com as pernas bem separadas”. ${ }^{166}$ Enquanto fala da dor física, sentida nas seções de tortura, abre o peito para expressar outra dor, em suas palavras, ainda pior: "Não só a dor material que dói com um choque elétrico no cu, que faz a dor aparecer ridícula! Dói mais a dor de estar perdendo um mundo!" ${ }^{167}$ E é com este texto que a movimentação dialoga, numa possibilidade de abertura... De uma dor lancinante que obriga a personagem a abrir o peito, buscar asas e alçar vôo. Não por acaso nos referimos a essa cena, no grupo, como a "cena do avião".

\footnotetext{
${ }^{164}$ Exercício descrito na página 55.

${ }^{165}$ Grifo do autor.

${ }^{166}$ CHEKHOV, Michael. Para o ator. São Paulo: Martins Fontes, 1996, p. 6.

${ }^{167}$ MIRANDA, Éjo da Rocha; QUINTAL, Ana Maria. Os filhos da Dita. São Paulo, 2011. (Anexo B)
} 


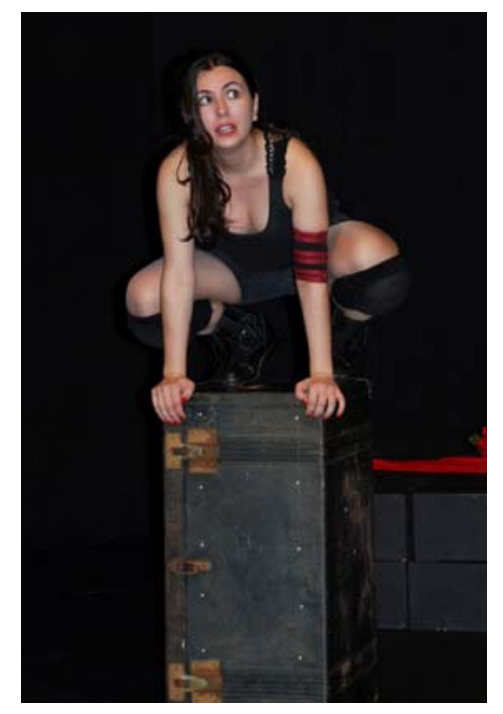

Iara na solitária: desabafo
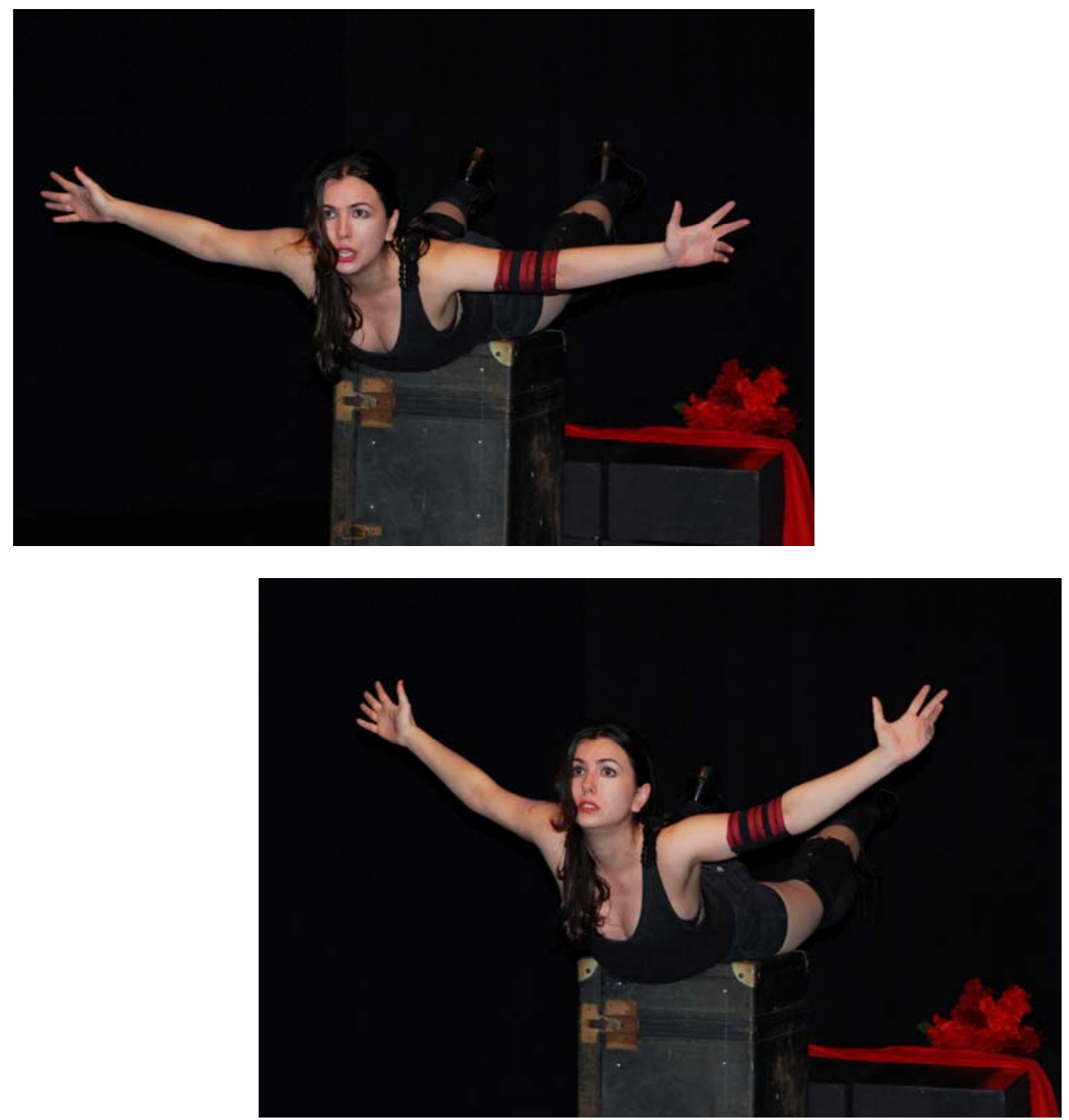

Sequência de fotos 11: Iara desabafando e abrindo suas feridas, expondo sua dor, "[...] a dor de estar perdendo um mundo!"

Período: maio/2010.

Local: Teatro Coletivo / São Paulo

Crédito: Marisa Quintal 
Exatamente a partir desse ponto, de peito aberto e dilacerado, tem início a sequência que vai servir como um tributo a nossos heróis da resistência caídos em combate, aqueles que foram barbaramente aniquilados. E isso se dá a partir de uma homenagem a Carlos Marighella ${ }^{168}$, que aqui representa a tantos e tantas...

A partitura física da cena (intitulada pelo grupo de "dança da morte de Marighella") foi criada anteriormente à concretização deste momento. Durante o treinamento de biomecânica junto ao Arlequins eu vinha criando novas sequências a partir dos études "o arremesso da pedra" e "golpe com adaga". Quando foi apresentada a proposta de movimentação ao diretor, optou-se por utilizá-la neste momento. As fotos na próxima página ilustram toda a movimentação.

Chegas de longa caminhada a este teu chão natal, território de tua infância e adolescência. Vens de um silêncio de dez anos, de um tempo vazio, quando houve espaço e eco apenas para a mentira e a negação. Quando te vestiram de lama e sangue, quando pretenderam te marcar com o estigma da infâmia, quando pretenderam enterrar na maldição tua memória e teu nome. Para que jamais se soubesse da verdade de tua gesta, da grandeza de tua saga, do humanismo que comandou tua vida e tua morte. Trancaram as portas e as janelas para que ninguém percebesse tua sombra erguida, nem ouvisse tua voz, teu grito de protesto. Para que não frutificasses, não pudesses ser alento e esperança. Escreveram a história pelo avesso para que ninguém soubesse que eras pão e não erva daninha, que eras vozeiro de reivindicações e não pragas, que eras poeta do povo e não algoz. Cobriram-te de infâmia para que tua presença se apagasse para sempre, nunca mais fosse lembrada, desfeita em lama. Esquartejaram tua memória, salgaram teu nome em praça pública, foste proibido em teu país e entre os teus. [...] Aqui estás e todos te reconhecem como foste e serás para sempre: incorruptível brasileiro, um moço baiano de riso jovial e coração ardente. [...] Tua luta foi contra a fome e a miséria, sonhavas com a fartura e a alegria, amavas a vida, o ser humano, a liberdade. ${ }^{169}$

Jorge Amado

\footnotetext{
${ }^{168}$ Carlos Marighella nasceu em Salvador, Bahia, em 5 de dezembro de 1911. Era filho de um imigrante italiano com uma negra descendente dos haussás, conhecidos pela combatividade nas sublevações contra a escravidão. Militante do PCB durante muitos anos, passou a vida entre legalidade e clandestinidade, desde a Era Vargas, tendo sido eleito Deputado Federal. Após o golpe de 1964, não concordando com os rumos do PCB e convencido da necessidade de partir para a luta armada, sai do partido e cria a ALN - Ação Libertadora Nacional. Foi assassinado no dia 4 de novembro de 1969, na Alameda Casa Branca, na cidade de São Paulo, em ação coordenada pelo delegado Sérgio Paranhos Fleury. Carlos Marighella foi sepultado por seus algozes como indigente no cemitério de Vila Formosa, onde permaneceu praticamente incógnito. Somente em dezembro de 1979, três meses após ter sido promulgada a Anistia e há dez anos de seu assassinato, seus familiares conseguiram resgatar seu corpo e transportá-lo para a Bahia. No cemitério de Quintas, em Salvador, há uma lápide desenhada pelo arquiteto Oscar Niemeyer, em que está gravada uma figura humana em posição de luta e uma frase muito cara a Carlos Marighella: "Não tive tempo de ter medo".

169 Texto escrito por Jorge Amado, amigo de Marighella e seu companheiro na bancada comunista da Assembléia Nacional Constituinte e na Câmara dos Deputados entre 1946 e 1948. Lido por Fernando Santana em 10 de dezembro de 1979 por ocasião do sepultamento dos restos mortais de Marighella em Salvador.

Fonte: http://marighellavive.blogspot.com/
} 
Sequência da cena Iara e dança da morte de Marighella
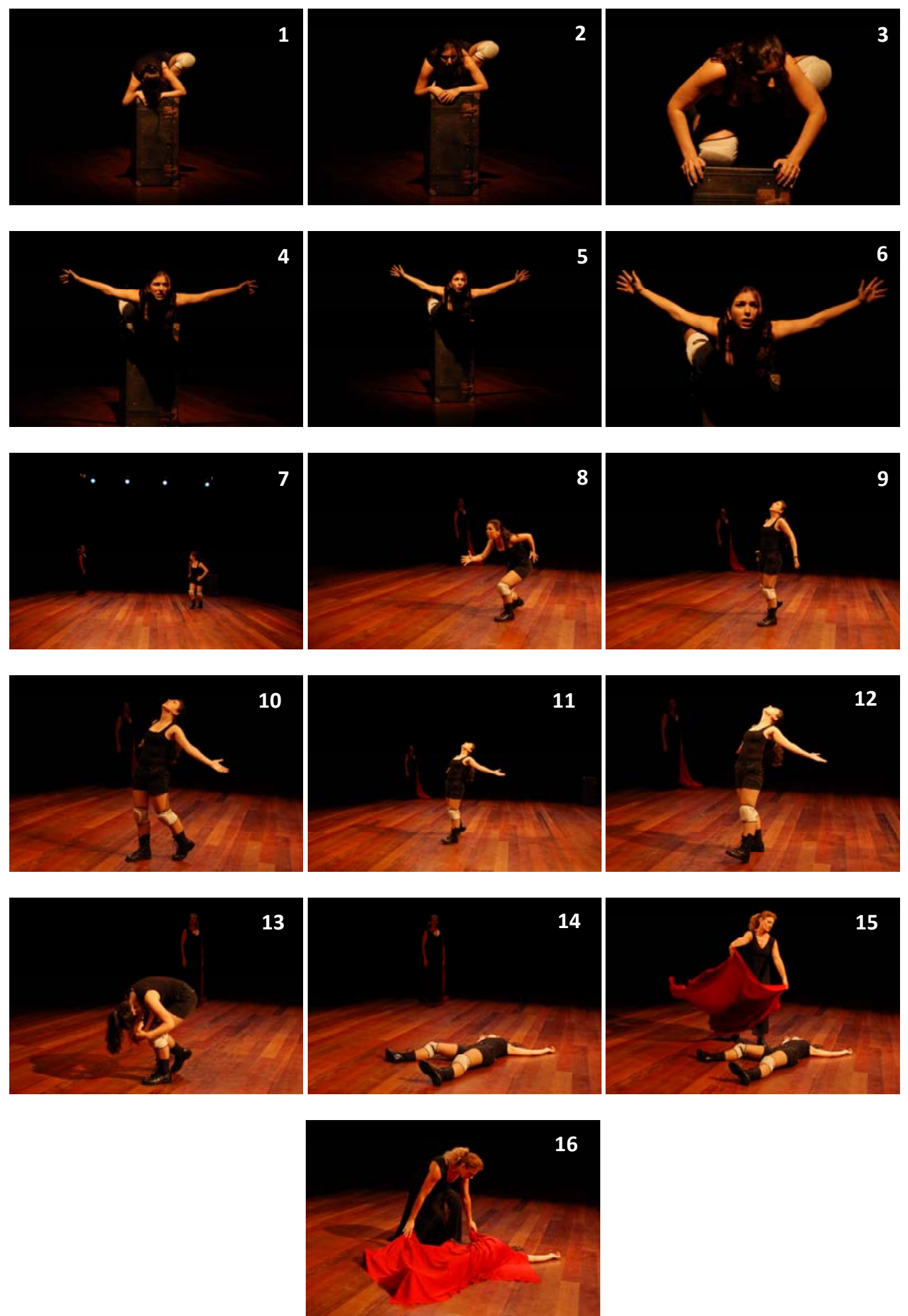

Sequência de fotos 12: cena de Iara: desabafo (fotos 1 a 6), preparação e corrida movimentos do étude "atirando a pedra" (fotos 7 e 8), caminhada em direção à morte e morte estilizada - inspiradas em movimentos do étude "golpe com adaga" (fotos 9 a 14), cobrindo o cadáver (fotos 15 e 16).

Data: 07 abril/2010.

Local: TUSP (Teatro da USP) / São Paulo

Evento: VII Mostra Experimentos TUSP/SP - participação do CEPECA - ECA/USP

Crédito: Marisa Quintal 
PRIMEIRO DE ABRIL

No dia em que se descobriu, como num primeiro de abril, o tudo que se mentiu, o tudo que se mentiu foi mentido de novo. Primeiro de abril! ${ }^{170}$

Esse pequeno poema cheio de ironia apresenta a piada feita: o golpe civil militar se deu no dia da mentira! Mas era o país que havia caído em fase de terror e escuridão.

A solução cênica que encontramos para essa "vinheta de ligação" ${ }^{171}$ foi recuperar e ressignificar uma partitura cênica que eu havia criado no processo de montagem de pra Não dizer que Não falei das Flores. Esta movimentação surgiu da relação e experimentação com o objeto: um paralelepípedo de isopor, envolto por uma manta de espuma, coberto por uma capa de malha. Ao buscar outras formas de utilização deste objeto (sempre presente nas obras do Arlequins) experimentei fazer um rolamento sobre o paralelepípedo e cair sentada - desse processo surgiu a cambalhota em que objeto e atriz se unem num determinado percurso.. Utilizar essa movimentação para a cena chamada $1^{\circ}$ de abril atendia a duas demandas: servir como citação a outra obra do grupo ${ }^{172}$ e carregar no tom de jogo, brincadeira, fazendo coro com o trocadilho proposto pelo texto.
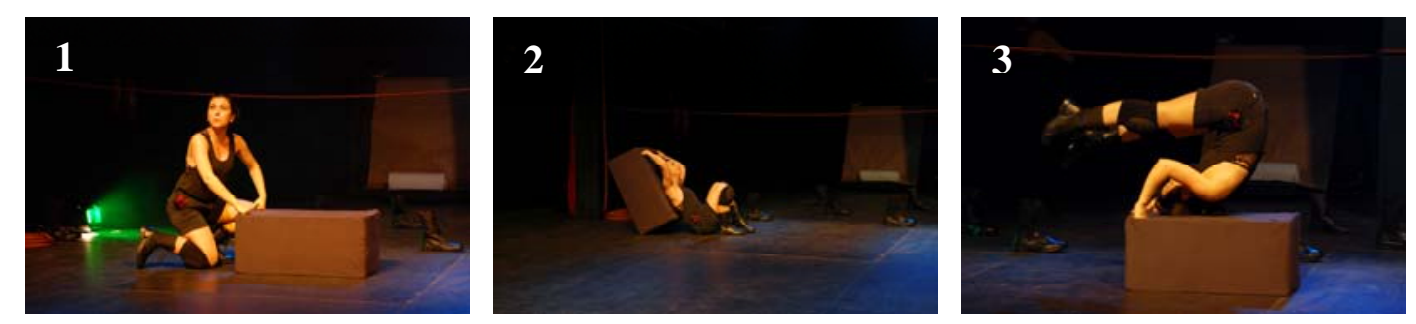

Sequência de fotos 13: preparação e início do texto (foto 1), sentando após rolamento (foto 2) e durante rolamento sobre paralelepípedo (foto 3 ).

Período: maio/2010.

Local: Teatro Coletivo / São Paulo

Crédito: Marisa Quintal

\footnotetext{
${ }^{170}$ MIRANDA, Éjo da Rocha; QUINTAL, Ana Maria. Os filhos da Dita. São Paulo, 2011. (Anexo B)

${ }^{171}$ Termo que usamos para designar cenas curtas que servem para ligar dois fragmentos distintos do espetáculo.

172 O Arlequins tem como hábito recuperar uma ou mais cenas e/ou efeitos de um espetáculo e utilizar em outro. O objetivo é fixar alguns paradigmas de linguagem do grupo, que podem ser facilmente identificados pelo público que acompanha a trajetória.
} 


\section{A EQUILIBRISTA}

Na borda da laje eu passava, trajando branco, com fumaça ao fundo, luz vermelha, segurando antiga sombrinha de renda no alto, ao som do início da música "O bêbado e a equilibrista" ${ }^{173}$ : esta é a descrição de uma cena criada para o exercício cênico Aquilo deu nisso em dezembro de 2007, realizado no CUCA, na sede da $\mathrm{UNE}^{174}$ em São Paulo.

$\mathrm{Na}$ montagem de Os filhos da Dita a música continuou a me rondar e me estimular e criar diálogo cênico com ela. Partindo do ilustrativo, busquei experimentar situações de desequilíbrio/equilíbrio típicos daqueles que caminham sobre cordas bambas... Então coloquei os coturnos que usávamos na primeira cena formando uma corda bamba simbólica. De início a cena foi criada em dupla (Bruno Garcia ainda fazia parte do elenco e nós dois criamos a primeira partitura em parceria): a "equilibrista" (eu) pisava sobre os coturnos (corda bamba na diagonal do palco) segurando um guarda-chuva com as cores do Brasil, o "bêbado" (Bruno) tentava, sem muito sucesso e com muitas trapalhadas, dar suporte a essa "equilibrista" decidida, em busca de outro horizonte. Com a saída dele a cena foi repensada, reestruturada e passou a haver somente 3 pés de coturnos, colocados por Ana Maria Quintal em cena que se configurou como 'vinheta de ligação' (ver nota 171) entre as cenas "Missa negra" e "Milagre brasileiro". Costa descreve a utilização de ícones da resistência cultural na concretização desta cena:

[...] os criadores deste trabalho adotaram a música de João Bosco e Aldir Blanc - O bêbado e a equilibrista na sonoplastia [...] para lhes dar régua e compasso nesta verdadeira operação-resgate da nossa memória: dos feitos truculentos para assegurar a continuidade de nossa condição de quintal do imperialismo à luta contra aquela violência, pelo fim daqueles tempos tenebrosos. Que, entretanto, como indicam os coturnos e a "operação sigilo eterno", persistem em larga escala. ${ }^{175}$

Iná Camargo Costa

\footnotetext{
${ }^{173}$ Composta por João Bosco e Aldir Blanc, a música de 1979 adquiriu ares de clássico da MPB na interpretação de Elis Regina.

${ }^{174}$ CUCA - Circuito Universitário de Cultura e Arte da União Nacional dos Estudantes (UNE) / São Paulo.

175 COSTA, Iná Camargo. Filhos da indigna Dita. Crítica à peça publicada na página da internet http://geracaoai5.blogspot.com/p/filmes-que-temos-visto.html.
} 


\section{Cena inspirada em "O bêbado e a equilibrista”}
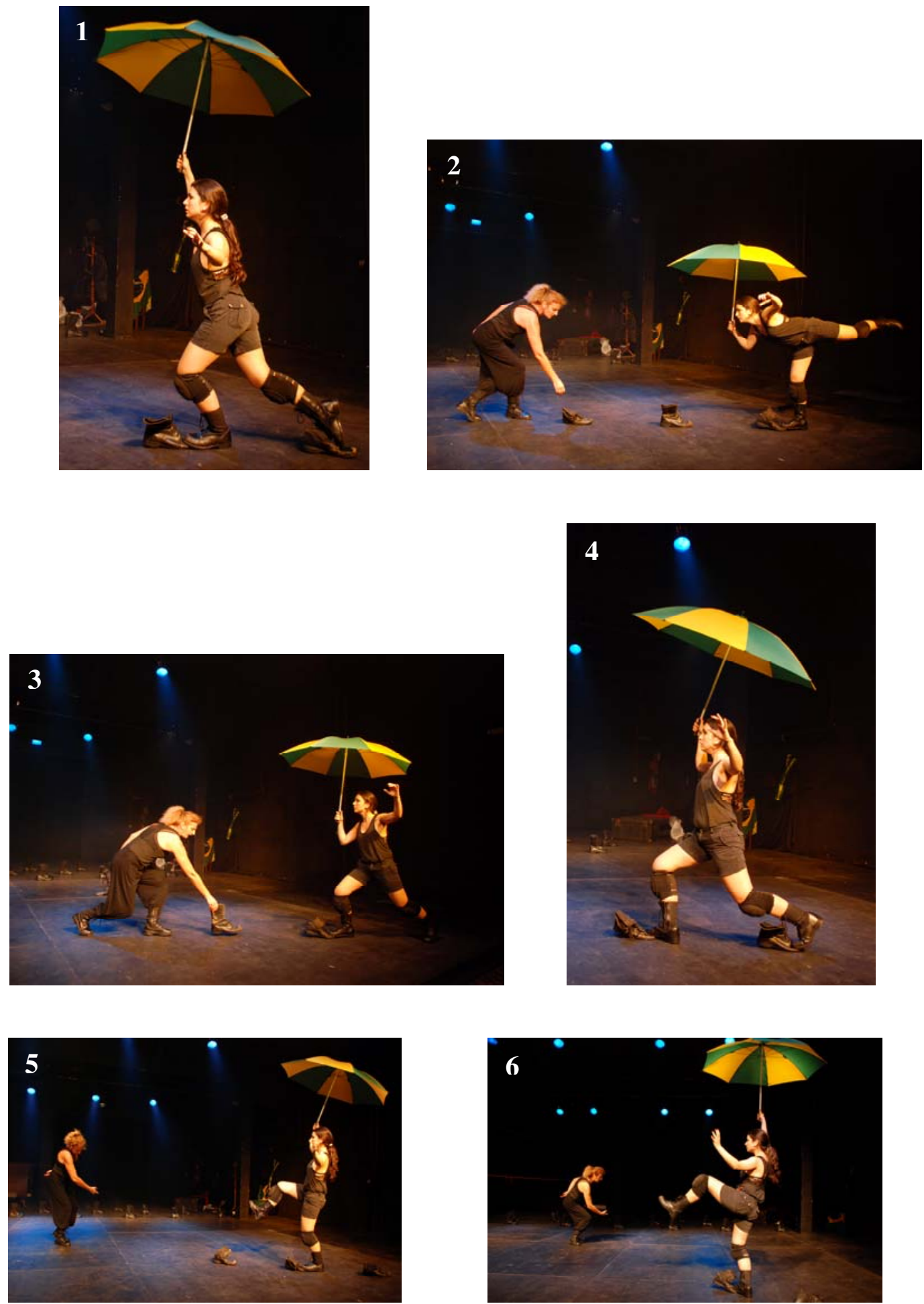

Sequência de fotos 14: a cena foi construída a partir da exploração de equilíbrio/desequilíbrio, tendo como objetivo pisar somente sobre os coturnos que são colocados em diagonal, no palco (fotos de 1 a 6 )

Nas fotos: Camila Scudeler e Ana Maria Quintal

Período: maio/2010.

Local: Teatro Coletivo / São Paulo

Crédito: Marisa Quintal 


\subsubsection{CRIAÇÃO COLETIVA}

A criação cênica do Arlequins surge, em grande medida, a partir da relação estabelecida entre todos os artistas diretamente relacionados com o projeto, principalmente entre os atores participantes. Podemos notar que, também no trabalho desenvolvido por Meyerhold, a criação partia, em grande medida, das relações. Leach afirma que:

Parte do recurso para um novo 'colorido emocional' no trabalho de Meyerhold é resultado de base sólida que os atores tinham em trabalhar com parceiros. Os atores de Meyerhold trabalhavam extremamente bem juntos[...]. As personagens de Meyerhold [...] às vezes pareciam existir somente na relação com outra personagem e acontecimentos externos. ${ }^{176} 177$

Por esse motivo justifica-se incluir aqui, além das descrições de cenas criadas individualmente, algumas descrições de criação coletiva.

\section{COTURNOS}

Uma das primeiras cenas que improvisamos no início do processo foi a do "Dia $1^{\circ}$ de abril". Buscávamos sugerir no palco a possível/provável confusão de militares - com seus tanques, caminhões, armas e cavalos - tumultuando a Avenida Brasil (o nome do local não é mera coincidência, como é de se esperar) na cidade do Rio de Janeiro, e a população que se deparava com tal situação.

O desenho da cena foi tomando outros caminhos, mas um elemento que surgiu nesse processo manteve-se e mantém-se inclusive do início ao fim do espetáculo: inúmeros pares de coturnos que povoam um canto do palco e deixam ativada a pergunta: o quê daquele ontem permanece vivo ainda hoje?

\footnotetext{
${ }^{176}$ LEACH, Robert. Stanislavsky and Meyerhold. Bern: Peter Lang, 2003, p. 155, 156.

${ }^{177}$ Part of the source for the new 'emotional colouring' in Meyerhold's work sprang from the solid basis the actors had in working with partners. Meyerhold's actors worked supremely well together (...). Meyerhold's characters, on the other hand, sometimes seemed to exist only in relation to other characters and external happenings. The question they were now addressing, therefore, was how to build an acceptable individual character, while retaining the ensemble's strengths of Biomechanics?
} 


\section{CONGESTIONAMENTO TELEFÔNICO}

Depois de inúmeras tentativas de solução para a cena que denominamos ‘congestionamento telefônico' começamos a improvisar com um telefone antigo. O texto que enunciamos com variação tonal nesta cena faz referência a conversas por telefone - verídicas e/ou imaginadas - entre alguns detentores das mais altas patentes das Forças Armadas (Exército, Marinha e Aeronáutica) no momento de definições do movimento golpista durante o dia $1^{\circ}$ de abril de 1964 , trechos de notícias de rádio e termina com a apresentação do que recebeu o nome de "Brother Sam Operation" - a participação ativa do Estados Unidos da América no planejamento, estabelecimento e continuidade do golpe civil militar no Brasil. Uma das experimentações sugeria a utilização do telefone, ou melhor, do fio buscando reproduzir a representação do movimento das ondas sonoras ${ }^{178}$ se propagando no ar exercício que utilizamos na Oficina Boas Falas, ministrada pelo grupo. Optamos então por ter como foco principal da cena a exploração de possibilidades de emissão vocal. A partir de uma trajetória simples: as atrizes atravessam o palco - da direita para a esquerda do espectador paralelamente ao proscênio, uma segurando o aparelho telefônico e outra, apenas o fone.
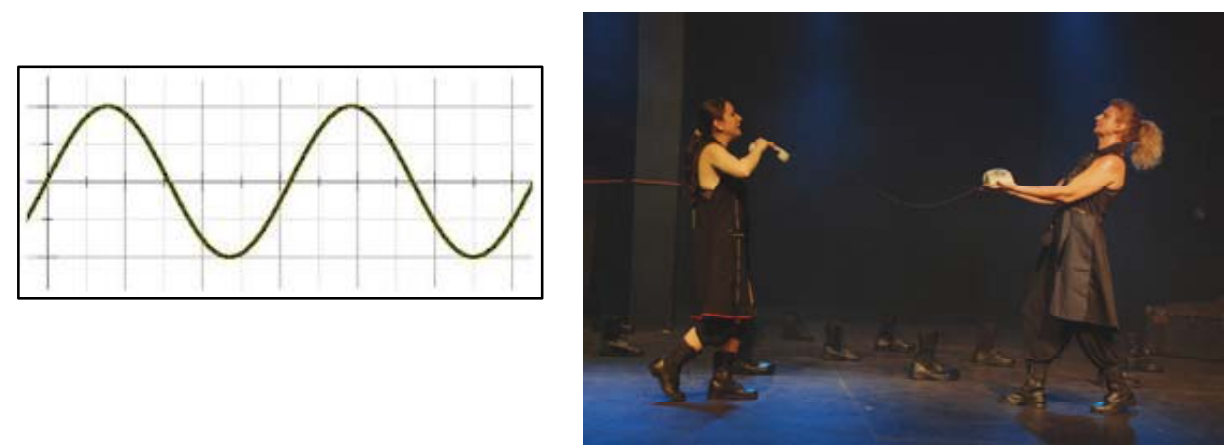

Sequência de fotos 15: o gráfico à esquerda é uma representação da onda sonora e mostra dois ciclos completos de oscilação de uma onda senoidal. O eixo horizontal representa a passagem do tempo enquanto que o vertical representa a variação de pressão em um determinado ponto do meio. Na foto à direita as atrizes buscam reproduzir, com o fio do telefone, tal reprodução e metaforizar o congestionamento telefônico.

Nas fotos: Camila Scudeler e Ana Maria Quintal

Período: maio/2010.

Local: Teatro Coletivo / São Paulo

Crédito: Marisa Quintal

\footnotetext{
178 “Som pode ser entendido como uma variação de pressão muito rápida que se propaga na forma de ondas em um meio elástico. Em geral, o som é causado por uma vibração de um corpo elástico, o qual gera uma variação de pressão corresponde no meio à sua volta. Qualquer corpo elástico capaz de vibrar rapidamente pode produzir som e, nesse caso, recebe o nome de fonte sonora. Em geral percebemos o som através de variações de pressão no ar que atingem nosso ouvido. Para que possamos perceber o som é necessário que as variações de pressão que chegam aos nossos ouvidos estejam dentro de certos limites de rapidez e intensidade. [...] Uma onda sonora pode ser representada em um gráfico bidimensional onde o eixo horizontal representa a passagem do tempo e o vertical a variação de pressão. Esse tipo de gráfico pode fornecer várias informações sobre o som."

Fonte: http://www.eca.usp.br/prof/iazzetta/tutor/acustica/introducao/som.html
} 


\section{PÊNDULO}

A cena e o efeito surgiram de experimentos com lanternas. As 4 lanternas que tínhamos em mãos foram amplamente testadas, experimentadas, exploradas... Dessa pesquisa e aproximação livre - feita fizemos com todos os objetos utilizados em cena - surgiu um efeito que reproduz um pouco do ar e tom das seções de tortura a que foram expostos tantos brasileiros que lutavam contra o regime de exceção: a luz pendular, geralmente resultante da movimentação de spots de luz que se encontravam nas salas de tortura. $\mathrm{O}$ pêndulo, conseguido com um recurso simples - um bastão fino de madeira encaixado na alça da lanterna - serve como apoio de mão e a lanterna fica 'livre', criando a movimentação pendular. Estava marcada aí, no desenrolar desta cena, a primeira quebra efetiva, a primeira saída em direção ao público. Pela própria dinâmica e demanda de uma cena de contato direto com os espectadores, por mais que se ensaie, ela só passa a existir quando existem efetivamente esses interlocutores. As relações que o ator estabelece com um espaço vazio, uma plateia imaginária durante o período de ensaio ganham forma e textura a partir do primeiro dia em que esse outro, com quem ele busca estabelecer diálogo, se materializa: na estreia. Após o início da temporada em escolas, essa cena tomou dimensões até então não provocadas. A ida ao 'lado de lá' do palco com uma lanterna nas mãos, entoando nosso coro dodecafônico ${ }^{179}$, se revelou intimidadora, incômoda, desconfortável para o público. ${ }^{180}$ Tratase de uma mulher com uma lanterna forte direcionada aos rostos, mãos, pés, o que pode haver abaixo, ao lado, atrás, uma sensação de revista, de vistoria, de exposição. Com isso passei a ter consciência - e então a ampliar e jogar - de que ali, naquele momento, reproduzíamos de alguma forma uma rotina à qual estavam expostos os cidadãos durante os anos de chumbo: revista, vistoria, com lanternas na cara, blitz de automóveis por toda cidade, tensão. Esse incômodo provocado nos interessa porque é mobilizador, instigante.

\footnotetext{
${ }^{179}$ O dodecafonismo é um sistema de organização de alturas musicais criada na década de 1920 pelo compositor austríaco Arnold Schoenberg. Como o esgotamento do sistema tonal no início do século XX os compositores buscaram maneiras alternativas de organização das notas musicais, posteriormente denominadas atonalismo, que não fossem baseadas na polarização de um eixo harmônico central como ocorre no tonalismo. Schoenberg compôs algumas peças desta maneira, porém, logo considerou o atonalismo demasiadamente sem regras. Construiu, então, um método para organizar os doze tons da escala cromática igualmente. Essa técnica foi apresentada como "sistema dos 12 tons", que logo ficou conhecida como dodecafonismo serial.

180 Às vezes como canto a ser ouvido e compreendido, outras como paisagem sonora, o coro dodecafônico criado pelo grupo em parceria com o músico Gregory Slivar dá o tom de inúmeras cenas do espetáculo. Aparece desde a primeira entrada das narradoras, com distintos andamentos. $\mathrm{Na}$ cena das lanternas em pêndulo aparece integralmente: "Ou, ou é, ou é, ou é, é, ou. Ou é, ou é, ou é, é, ou. Ou é, ou é, ou é, é, eoeoeo eoeoeo eoeoeoééée... Filhos da pátria Brasil, filhos da Dita. Filhos da Dita, filhos da pátria, filhos. Filhos da pátria Brasil, filhos da Dita!"
} 


\section{Cena na plateia com lanterna}
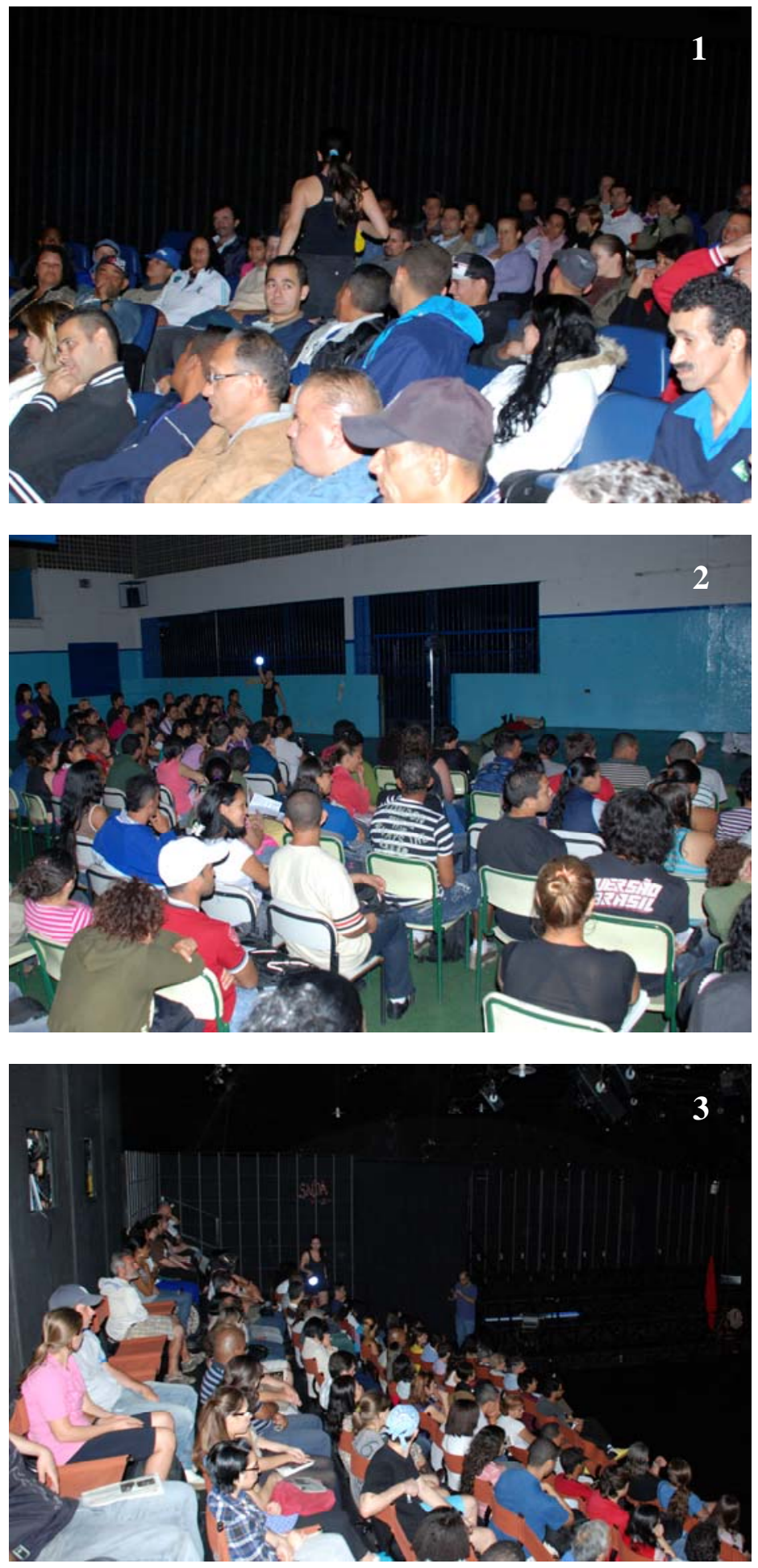

Sequência de fotos 16 :

Foto 1 - Apresentação para alunos do CIEJA Sapopemba realizada no CEU Sapopemba / São Paulo (maio/ 2011)

Foto 2 - Apresentação para alunos na E.E. Prof ${ }^{\text {a }}$ Zenaide Vilalva de Araújo / São Paulo. (abril/ 20110 Foto 3 - Apresentação no VI Engenho mostra um pouco do que gosta / São Paulo (13 ago. /2011) Crédito: Marisa Quintal 


\section{LAVARAM A RUA}

Para cena final do espetáculo, optamos por recuperar, adaptar e ressignificar texto que esteve presente na peça Marotinho, de $1976^{181}$. Interessava suscitar o questionamento, inquietar o espectador, deixar no ar o estado de coisas. Desnaturalizar a situação para que fique evidente sua condição de mutável. A poesia escrita em meados da década de 1970 nos parece ainda muito atual:

- Lavaram a rua!

- Dia novo, rua nova.

- Mesmo a poeira é outra. Nenhuma coisa fica nessa calçada, onde todo dia se compra o pão com suor do rosto.

- É gente que vai pro trabalho, gente que vai pra feira... Quando volta é tão escuro o caminho que não vê as pedras no chão, não vê a lua no céu...

- Não vê mesmo a indiferença com que passa todo dia no mesmo lugar, sem, contudo nada ver. É desse jeito que dorme, que pensa, que vive, dessa maneira se esquece de desconfiar do cheiro bom que vem da rua, da poeira nova da rua.

- Assim se passam as coisas durante o dia, até que de madrugada, antes de todo mundo, o lixeiro venha varrer o sangue, esguichar água onde só o sereno deveria bastar prá lavar a noite.

- Lavaram a rua...

- Que teria havido?

- Alguém viu?

- Ninguém viu?

- O sereno apagou a noite, e a gente que passa vai cuidar da vida, ler no jornal a notícia que bem debaixo dos seus pés foi palco de crime na escuridão.

Definido o texto, o estímulo para criação da cena foi um exercício proposto por Yedda Carvalho Chaves em nosso treinamento de biomecânica: saltar poças d'água imaginárias. Naquele momento, o objetivo do jogo era deixar os pés se deslocarem, sem antecipar a movimentação, criar espaços, deixar o corpo todo em alerta, criar "olhos nos pés", deixar que o corpo se reorganize durante a movimentação, reaja ao desequilíbrio. As poças d'água que deveriam ser saltadas transformaram-se em poças de sangue. A enunciação do texto surge, a cada apresentação, a partir da movimentação.

\footnotetext{
${ }^{181}$ Espetáculo montado pelo Grupo Pespectiva de Teatro Amador - grupo que passa a se chamar Arlequins
} em 1986. 


\section{Lavaram a rua}
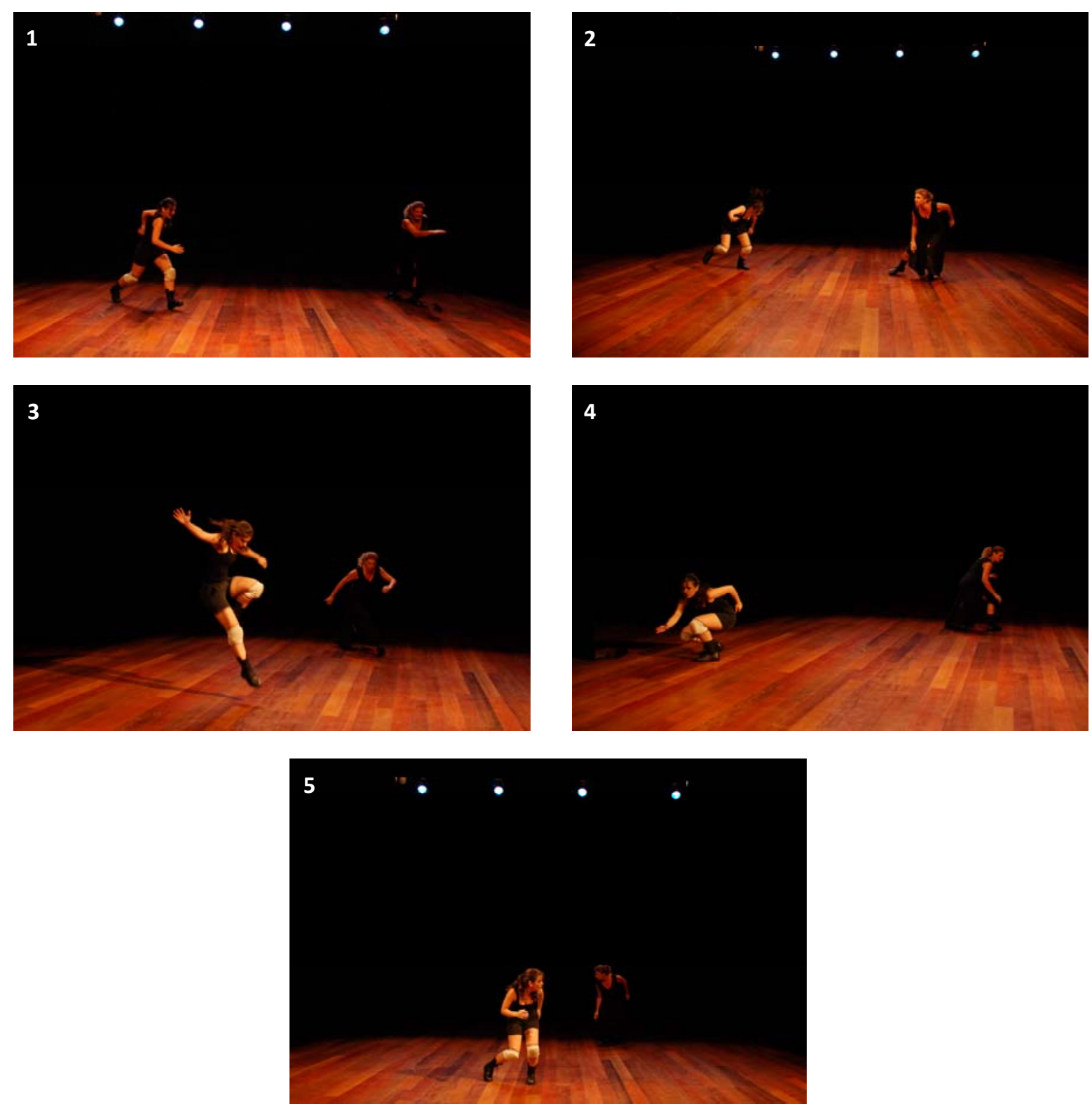

6

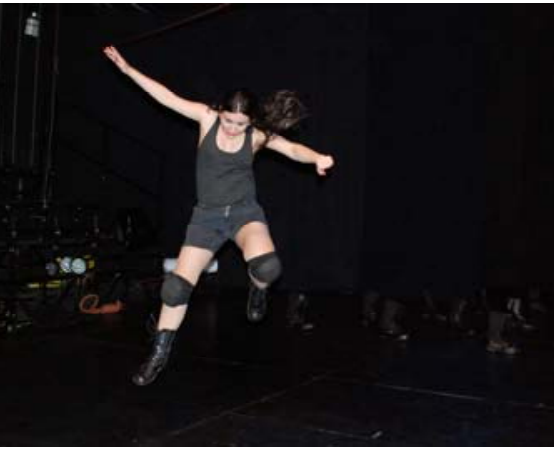

7

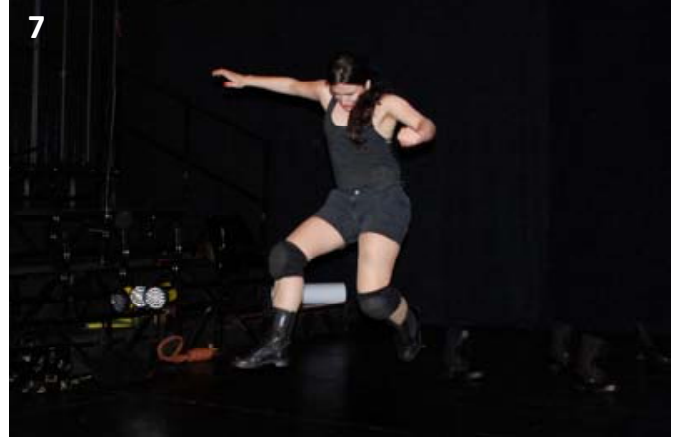

Sequência de fotos 17 :

fotos 1 a 5 - VII Mostra Experimentos TUSP/São Paulo (07 abril/2010).

fotos 6 e 7 - VI Engenho mostra um pouco do que gosta / São Paulo (13 ago/2011)

Nas fotos: Camila Scudeler e Ana Maria Quintal

Crédito: Marisa Quintal 


\subsection{REGISTRO FOTOGRÁFICO DE CENAS DO ESPETÁCULO}

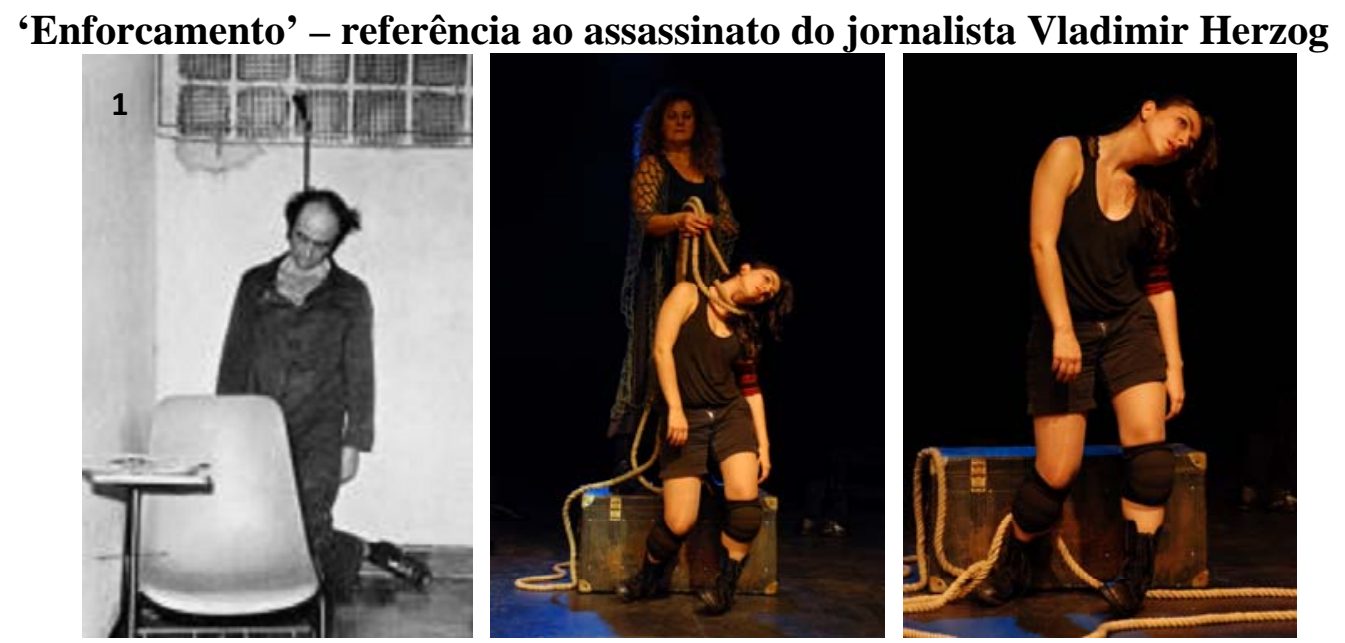

No dia 25 de outubro de 1975 o jornalista e professor Vladimir Herzog foi encontrado morto, enforcado no DOICODI de São Paulo. Embora a causa oficial do óbito, divulgada pelo governo, seja suicídio por enforcamento, há consenso na sociedade brasileira de que ela resultou de tortura. Nas fotos divulgadas há várias inverossimilhanças. Uma delas é o fato de que ele se enforcou com um cinto, objeto que os prisioneiros do DOICODI não possuíam. Além disso, suas pernas estão dobradas e no seu pescoço há marcas de estrangulamento.

Sequência de fotos 18: foto 1 - Vladimir Herzog já morto;

foto 2 - a personagem Iara é enforcada em construção física que remete à foto de Vladimir;

foto 3 - mesmo sem a corda no pescoço, mantendo a postura.

$\mathrm{Na}$ foto 2: Camila Scudeler e Ana Maria Quintal

Período fotos 2 e 3: maio/ 2011 - Teatro Coletivo / São Paulo

Crédito fotos 2 e 3: Marisa Quintal

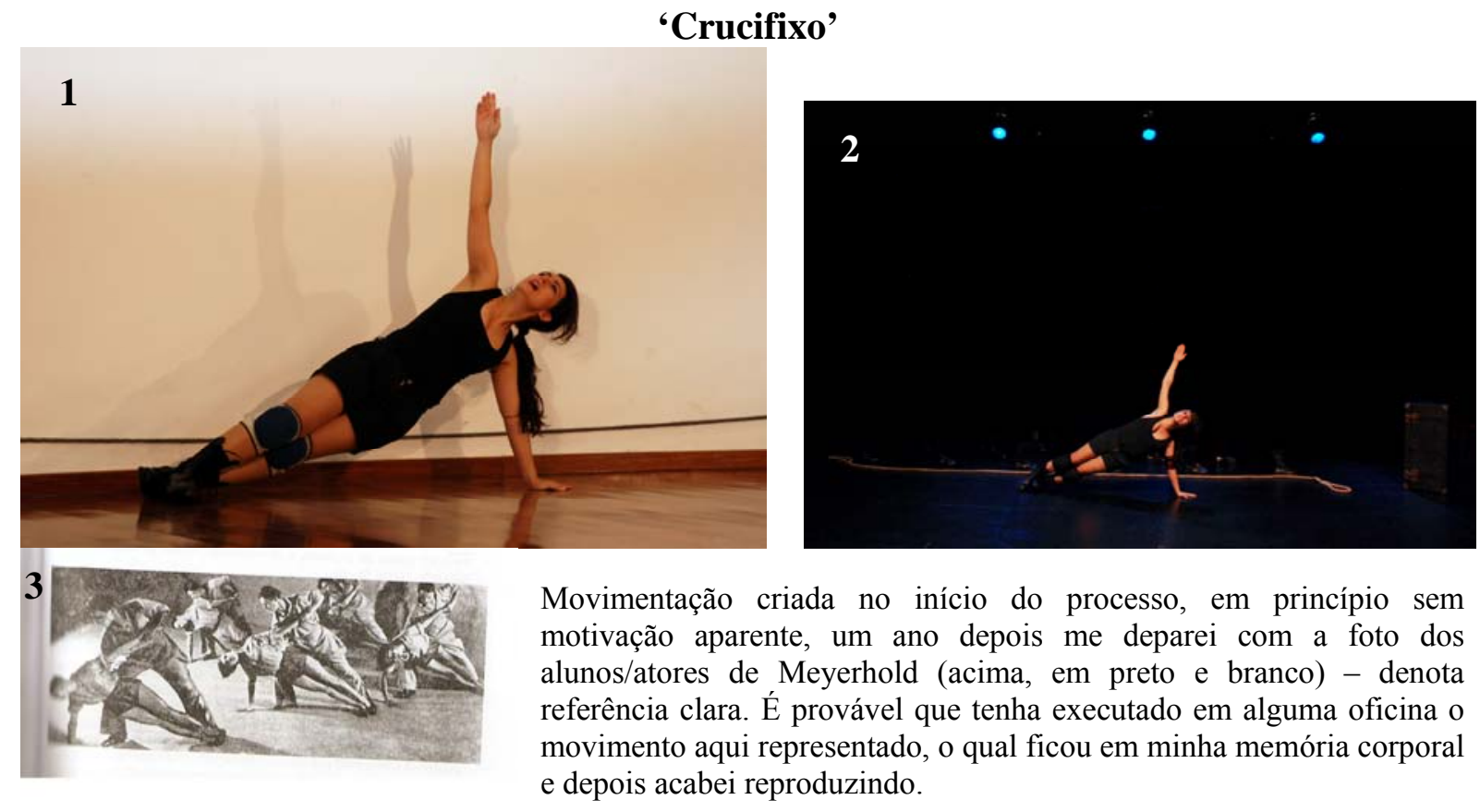

Sequência de fotos 19:

foto 1 - estreia da temporada experimental na ETEC Prof. Aprígio Gonzaga /São Paulo (16 mar/2011)

foto 2 - Engenho mostra um pouco do que gosta VI / São Paulo (13 ago/2011)

foto 3 - Exercício de biomecânica executado por alunos/ atores de Meyerhold.

Crédito fotos 1 e 2: Marisa Quintal. 


\section{Torções}
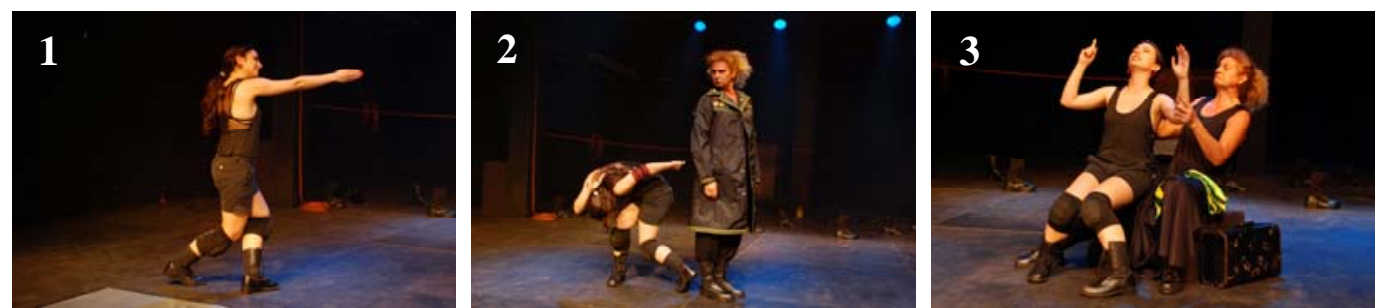

Sequência de fotos 20:

Nas fotos 2 e 3: Camila Scudeler e Ana Maria Quintal

Período: maio / 2011

Local: Teatro Coletivo / São Paulo

Crédito: Marisa Quintal.

\section{Oposições}
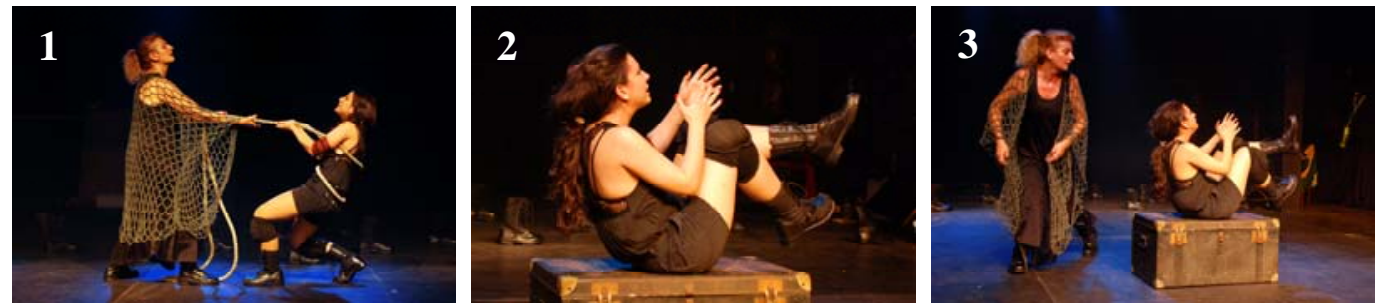

Sequência de fotos 21:

Nas fotos 1 e 3: Camila Scudeler e Ana Maria Quintal

Período: maio / 2011

Local: Teatro Coletivo / São Paulo

Crédito: Marisa Quintal.

\section{Marionete - Tancredo}
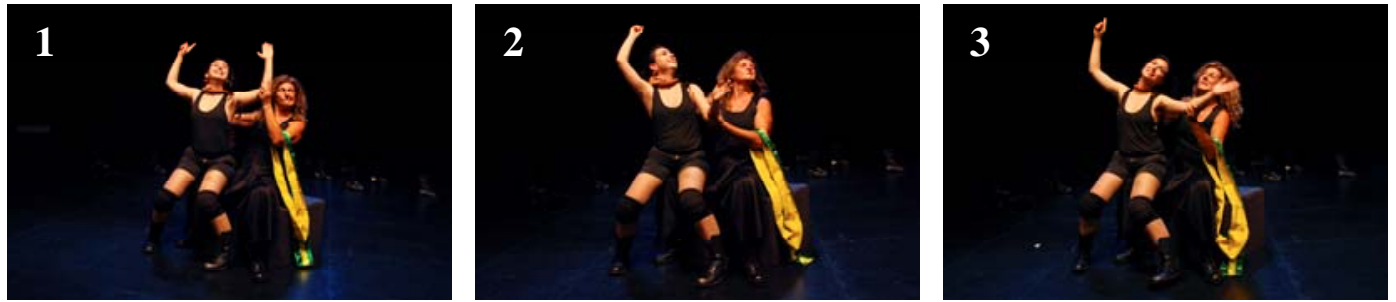

A despeito do que se ouve principalmente dos detratores do teatro épico-dialético - e muitos, por preconceito esperam - o espetáculo teatral que tem como norte um olhar crítico da sociedade e que espera inquietar o espectador com sua obra de arte, não pode resumir-se a uma sequência séria e desinteressante do ponto de vista técnico e estético. Muito pelo contrário. O riso é um elemento essencial no processo de fruição da obra. Benjamin ressalta: "As vibrações físicas produzidas pelo riso oferecem melhores ocasiões para o pensamento que as vibrações da alma. O teatro épico só é luxuriante nas ocasiões que oferece para o riso." 182 A cena acima, que apresenta a figura de Tancredo Neves como uma marionete/ventríloquo é uma, entre várias no espetáculo, em que optamos pela veia cômica para expressar nossa inquietação e dialogar com os espectadores.

Sequência de fotos 22:

Nas fotos 1, 2 e 3: Camila Scudeler e Ana Maria Quintal

Período: maio / 2011

Local: Teatro Coletivo / São Paulo

Crédito: Marisa Quintal.

${ }^{182}$ BENJAMIN, Walter. O autor como produtor. In: Magia e técnica, arte e política: ensaios sobre literatura e história da cultura. São Paulo: Brasiliense, 2010, 1985, p. 134. 
Fases de experimentação cena “Jango” - posição da corrida da biomecânica

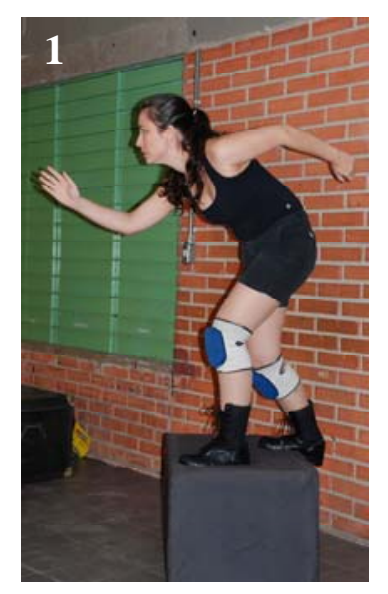

Sequência de fotos 23 :

Foto 1 - primeiras experimentações - Apresentação para alunos da E.E. Prof ${ }^{a}$ Carmelinda Marques Pereira/São Paulo (mar/2011)

Foto 2 - Demonstração da posição de corrida da biomecânica postura-base para cena do 'Jango'. TUSP/São Paulo (abril/2011)

Foto 3 - Posição na cena. TUSP/São Paulo (abril/ 2011)

Foto 4 - Posição na cena. Teatro Coletivo/São Paulo (maio/ 2011)

Crédito: Marisa Quintal
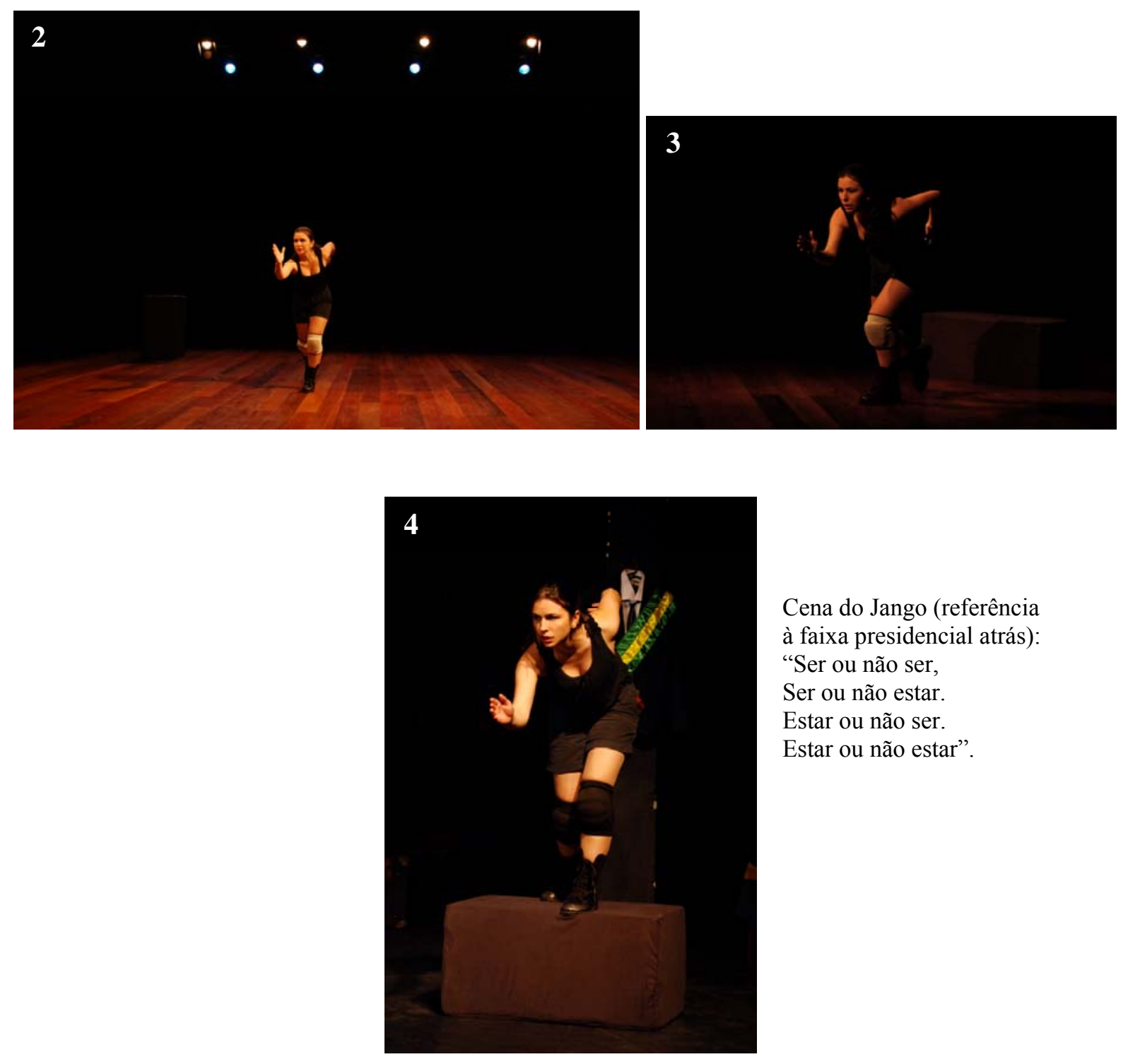

Cena do Jango (referência à faixa presidencial atrás):

"Ser ou não ser,

Ser ou não estar.

Estar ou não ser.

Estar ou não estar”. 


\section{RELAÇÃO ATOR/ESPECTADOR}

Mas o teatro que efetivamente desejo não é aquele que aspira à ação direta nem aquele realizado por uma pequena comunidade fechada nela mesma: é um teatro de representação e de reflexão sociais.

Bernard Dort ${ }^{183}$

Um ensinamento crucial vem também de Augusto Boal: recusa à ideia de cultura como privilégio de classe. Longe da ideia populista de "levar arte ao povo", a busca pela ampliação do diálogo apresenta-se como principal objetivo. A fruição da arte é elemento importante para o crescimento humano resultando na ampliação da consciência e autoconsciência. Peixoto apresenta:

[...] a arte exerce significativa função no processo de humanização do homem, por desencadear um processo de reflexão profundamente educativo, que só pode resultar em crescimento humano. Sobretudo quando se trata de obra que permite-privilegia a fruição estética ativa-interativa, por livre adesão do indivíduo e da coletividade presente, e, de modo especial, se isso tudo ocorre dentro do âmbito da vida cotidiana, no qual se dão as relações imediatamente humanas. Disponibilizada de modo gratuito, a arte inserida no cotidiano pode vir a ser um momento de veemente exercício da liberdade, de ampliação da consciência-autoconsciência e de intenso prazer sensóriointelectual desvinculado das relações de posse e dominação que permeiam a quase totalidade das relações humanas, na sociedade capitalista contemporânea. ${ }^{184}$

A partir disso podemos conceber que a ampliação de acesso ao fazer artístico é também responsabilidade do artista, sendo o Brasil um país que não tem uma tradição de participação dos trabalhadores no processo de produção e fruição dos bens culturais.

"Nos últimos 30 anos muitos trabalhos emergiram os quais falam com povos geralmente dominados e marginalizados [...] Muitos destes teatros emergentes conscientemente procuraram a centralidade do espectador como sujeito do drama, mas como um sujeito que pode pensar e agir" ${ }^{185}{ }^{186}$, um espectador produtivo e emancipado.

Embora haja espectadores que vão ao teatro para acompanhar os sucessos de uma personagem, Brecht propõe que o público deva estar distante, não se envolver totalmente a fim de analisar cientificamente, e verificar a causalidade. $\mathrm{O}$ espectador deve ter possibilidade

\footnotetext{
${ }^{183}$ DORT, Bernard. O teatro e sua realidade. São Paulo: Perspectiva, 1977, p. 57.

${ }^{184}$ PEIXOTO, Maria Inês Hamann. A arte no cotidiano: consciência e autoconsciência. In: Anais III Fórum de pesquisa científica em arte. Escola de Música e Belas Artes do Paraná. Curitiba, 2005, p. 164.

${ }^{185}$ BENNETT, Susan. Theather audiences: a theory of production and reception. London: Routledge, 1990, p. 1.

${ }^{186}$ Over the last thirty years many theaters have emerged which speak for dominated and generally marginalized peoples [...] Many of these emergent theaters have self-consciously sought the centrality of the spectator as subject of the drama, but as a subject who can think and act. That productive and emancipated spectator is my subject.
} 
de recuo, de espanto, de questionamento. Há duas formas de experiência para o espectador (informação verbal) ${ }^{187}$ :

- experiência 'carrossel': a pessoa está sofrendo as sensações de sobe-e-desce, mas não sai do lugar

- experiência 'planetário': a pessoa está aparentemente passiva, mas está vendo os corpos celestes ao mesmo tempo em que busca ordenar as informações ela mesma.

As proposições de Bertolt Brecht acerca da relação ator/espectador, precedido pelas propostas aportadas por Meyerhold, modificaram essa que é a condição sine qua non do teatro, e não se restringiram a ser modificações formais, mas redefiniram os papéis sociais de todos os participantes de tal expressão artística.

Propondo quebrar a quarta parede e colocando o espectador em posição crítica, responsável por completar com sua imaginação e seu repertório uma apreensão única da peça, Meyerhold abriu precedentes para estimular uma postura mais ativa do espectador.

Brecht ampliou e aprofundoua essa proposta, e afirmou: “[...] a relação entre o ator e seu público deveria ser a mais livre e direta possível. Ele simplesmente tem algo a comunicar e a mostrar e esta atitude, daqui em diante, deveria servir de base." 188

Buscando pensar o lugar do espectador à luz de um breve recorrido histórico acerca de seu papel- e o tratamento dado a ele pelos teatristas desde a Grécia antiga (ou seja, desde o início do desenvolvimento do teatro ocidental como o entendemos) - Susan Bennett ressalta, entre outros exemplos, apresentação de Aristóteles na Poética em que afirma que "[...] o espectador é principalmente de interesse na medida em que ele prova o poder dos bons textos trágicos / performances"189 190 . No entanto, Bennett ressalta que "[...]mais importante por sua influência imediata tanto na prática quanto na teoria teatral, é o trabalho de Meyerhold". ${ }^{191} 192$ Desde seus primeiros trabalhos, Meyerhold desafiou as convenções do teatro naturalista e focou sua atenção na criatividade dos espectadores questionando a necessidade de grandes aparatos que visavam o convencimento do público. "Meyerhold desmistificou o aparato técnico do teatro. Todas as armadilhas do teatro comercial foram evitadas em favor de montagens não-ilusionistas e optou por utilizar componentes cênicas

\footnotetext{
${ }^{187}$ Parágrafo escrito a partir de anotações feitas durante a disciplina "Aspectos do teatro dialético de Bertolt Brecht" ministrada pelo Prof. Dr. Sérgio Ricardo de Carvalho no programa de pós-graduação da ECA/USP durante o primeiro semestre de 2009.

${ }^{188}$ BRECHT, Bertolt. Estudos sobre teatro. Rio de Janeiro: Nova Fronteira, 1978, p. 168.

${ }^{189}$ BENNETT, Susan. Theather audiences: a theory of production and reception. London: Routledge, 1990, p. 4.

${ }^{190}$ The audience is chiefly of interest in so far as they prove the power of good tragic texts/performances.

${ }^{191}$ Ibidem, p. 5.

${ }^{192}$ [...] more important for its immediate influence on theater practice and theory, is the work of Meyerhold.
} 
politicamente relevantes (cartazes, folhetos, atores na plateia para guiar reações). A quebra da barreira tradicional do proscênio, como Edward Braun assinala, providenciou [...] uma vantagem adicional [...] e isso implicava em uma polêmica contra o teatro burguês de escapismo e ilusão'.”193 194

Walter Benjamin, filósofo alemão, ressalta que "[...] o teatro épico (brechtiano) se dirige a indivíduos interessados, que não pensam sem motivo" ${ }^{195}$. E segue citando Brecht ao afirmar que seu teatro já não é mais um “[...] agregado de cobaias hipnotizadas, e sim uma assembleia de pessoas interessadas, cujas exigências ele precisa satisfazer." 196

Esta introdução ao assunto, apresentando alguns dos principais instigadores de uma ampla e intensa relação entre ator e espectador, serve para enfatizar que este é um dos objetivos centrais no Arlequins, e que desperta em mim o maior interesse. Baseando seu discurso em pensamento elaborado por Agnes Heller em La revolución de la vida cotidiana, Peixoto afirma que "[...] os indivíduos e, em especial, educadores e artistas que vivem sua cotidianidade no seio da sociedade capitalista - marcados pela alienação - necessitam ter como meta o estabelecimento do exercício da reflexão e da crítica como tônica para a criação de um modus vivendi não alienado. Para tanto [...], não se pode intentar uma formulação teórica, simplesmente. Uma ação coletiva se impõe, aliada às ações dos indivíduos no seu campo de atuação específico. O artista, então, construirá sua obra nesse espírito."197

Este é o espírito que guia nossa atuação. Por esse motivo a relação entre ator e espectador está presente neste trabalho a começar pelo título. Mais do que me propor a escrever um capítulo sobre o tema, busquei discorrer acerca dessa relação ao citar exemplos de como ela ocorre nas distintas fases de montagem, produção e apresentação de um espetáculo: como um dos estímulos principais para que montássemos Os filhos da Dita (interesse do público expresso em debates durante temporada de outro espetáculo), participação dos espectadores nos eventos que ocorreram paralelamente a essa montagem (por exemplo, Segundas Opiniões), participação do público nas primeiras aberturas que fizemos do

\footnotetext{
${ }^{193}$ BENNETT, Susan. Theather audiences: a theory of production and reception. London: Routledge, 1990, p. 6.

${ }^{194}$ Meyerhold demystified the technical apparatus os theater. All the trappings of commercial theater were eschewed in favour of non-ilusionistic staging and politically relevant scenic components (placards, leaflets, actors in the audience to guide reactions). The breaking of the traditional barrier of the proscenium provided, as Edward Braun points out, 'an additional advantage...that this implied a polemic against the bourgeois theater of escapism and illusion'.

${ }^{195}$ BENJAMIN, Walter. Magia e técnica, arte e política - Ensaios sobre literatura e História da cultura. São Paulo: Brasiliense, 1986, p. 81 .

196 Ibidem, p. 79.

${ }^{197}$ PEIXOTO, Maria Inês Hamann. A arte no cotidiano: consciência e autoconsciência. In: Anais III Fórum de pesquisa científica em arte. Escola de Música e Belas Artes do Paraná. Curitiba, 2005, p. 162.
} 
processo (ainda em fase de desenvolvimento intermediário da dramaturgia) e principalmente (e de maneira ainda mais efetiva) durante a temporada experimental - cujo objetivo era debater e escutar de nossos primeiros interlocutores do outro lado da ribalta como a peça estava chegando até eles.

Dificuldade - ou não - de se compreender as obras do Arlequins: uma análise

Frequentemente ouvimos comentários, em geral por parte de professores e artistas, sobre a dificuldade encontrada por um público não habitué de teatro - em geral, alunos de escolas públicas localizadas na periferia da cidade de São Paulo - em compreender as obras do Arlequins, argumentando que o grupo trata de assuntos difíceis, com referências sofisticadas, o que demandaria amplo conhecimento prévio acerca do assunto para serem compreendidas. Interessante notar, no entanto, que este público do qual esses professores pretendem ser porta vozes, buscando assim 'protegê-los' das supostas dificuldades de leitura, é exatamente aquele que reage com maior vivacidade à maioria das provocações que as peças do grupo - e em particular Os filhos da Dita - propõem. Cabe aqui fazer um parênteses e contar uma anedota que ilustra bem uma dessas situações vivenciadas pelo grupo.

O ano era 2006, e estávamos em cartaz com a peça pra Não dizer que Não falei das Flores ${ }^{198}$ em um teatro na cidade de São Paulo. Após a apresentação lotada de alunos do EJA ${ }^{199}$, nós, atores, e o diretor nos sentamos, como de costume, à beira do palco e iniciamos o debate/conversa e convidamos a todos os presentes para participarem com comentários, perguntas, críticas, divagações... O objetivo do grupo com essa atividade é instaurar uma conversa coletiva, deflagradora de discussão. A certa altura, com a conversa acontecendo e o debate já estabelecido, levanta-se uma das professoras que acompanhavam os alunos no teatro e começa a elogiar a montagem, a grandiloqüência do texto, o conteúdo crítico, mas lamenta o fato de tratar-se de matéria de difícil compreensão, o que impossibilitava aos alunos acompanhá-la. Um dos alunos, sentado em outro extremo da sala, levanta-se num rompante e começa a argumentar com ela. Questiona o lugar de porta-voz dos alunos que ela buscava ocupar, salientando que ele tinha sim acompanhado e entendido muito bem a peça, e isso porquê aquilo que a obra planteava ele vivenciava na pele, no dia-a-dia, assim como os

\footnotetext{
${ }^{198}$ A peça, escrita por Éjo de Rocha Miranda e Ana Maria Quintal, estreou em setembro de 2005 e ficou em cartaz até dezembro de 2009, tendo sido assistida por mais de 20 mil pessoas nas cidades de São Paulo, interior e litoral do estado. Foi um dos espetáculos convidados da III Mostra de Referências Teatrais de Suzano em 2007 e do XIII Festival de Teatro de La Habana, Cuba em 2009. Foi apresentada ainda em Santa Clara, Cuba e Caracas, Venezuela também no ano de 2009. Durante esse período participaram do elenco Ana Maria Quintal, Camila Scudeler (atrizes que se mantiveram no elenco durante todo o processo), Alexandre Garcia, Carlinha Passos, Danielle Agostinho, Luis Vitor Maia (músico) e Sérgio Garcia.

${ }^{199}$ Ensino de Jovens e Adultos, antigo Supletivo.
} 
demais colegas ali presentes. Foi ovacionado por seus pares que, nesta fala, se sentiram representados. Tal evento não deixa de revelar a luta entre os dois grupos, pelo contrário, deixa explícita a existência da luta de classes

Trata-se de um exemplo entre tantos outros que vimos tendo nos últimos anos a fim de ilustrar as motivações de nossas escolhas no palco, uma escolha radical de não facilitar desmedidamente em busca de uma possibilidade de acompanhamento vago. Até porque, como ressalta o diretor alemão Mathias Langhoff, “[...] não é preciso clarear as coisas que não são claras. A confrontação deve ser feita com um mundo que não é claro. Uma confrontação é mais importante do que a tentativa de esclarecer ou de criar uma única lógica." 200

\subsection{ALTERAÇÕES A PARTIR DO CONTATO COM O PÚBLICO}

Em obras de teatro como Os filhos da Dita, o caráter quase 'aberto' e 'inconcluso' é determinante e possibilita que ela sofra modificações constantes, que vêm a contribuir com um melhor encaminhamento das funções propostas. Nesse sentido, qualquer relação com o espectador é passível de influenciar o resultado.

Assim, dada a necessidade de comprovação de maneira direta inerente a um trabalho acadêmico dessa natureza, optamos por descrever três alterações que ocorreram durante temporada experimental (projeto escola), cujo objetivo principal foi, deliberadamente, confrontar o objeto que tínhamos construído a portas fechadas com nosso interlocutor: o espectador. ${ }^{201}$ "A finalização dos espetáculos dá-se necessariamente no contato com a comunidade. É a partir das reações do público durante a peça, das enquetes, entrevistas e debates que o espetáculo vai sendo aparado, transformado, aforado." 202

1) Alteração da ordem de cenas

A cena em que a personagem Iara encontra-se na solitária ${ }^{203}$ vinha, num primeiro recorte, na sequência da cena do Milagre brasileiro. Pensada desta maneira para, inclusive, fazer a ponte com 'alguns' dos efeitos colaterais do pseudo desenvolvimentismo que ocorria

\footnotetext{
${ }^{200}$ Entrevista com Mathias Langhoff publicada em CARVALHO, Sérgio de e colaboradores. Atuação crítica Entrevistas da Vintém e outras conversas. São Paulo: Expressão Popular; Companhia do Latão, 2009, p. 130. ${ }^{201}$ Cabe registrar que o ponto chave, e mais prazeroso, resultante do fato deste projeto ter sido patrocinado, foi a possibilidade de apresentarmos o espetáculo gratuitamente em escolas públicas da cidade - durante temporada experimental - e também disponibilizar $40 \%$ dos ingressos gratuitamente aos alunos durante temporada oficial, no Teatro Coletivo, ambos na cidade de São Paulo.

${ }^{202}$ GARCIA, Silvana. Teatro da militância - A intenção do popular no engajamento político. São Paulo: Editora Perspectiva, 2004, p. 187.

${ }^{203}$ Descrita no item 4.2.1.
} 
no Brasil naquele momento - 1968-1973 - o caráter cômico da cena dificultava em muito o contato com a seriedade que a cena seguinte propunha. Desta maneira, começavam a acompanhar às gargalhadas a descrição que a personagem faz das barbáries às quais tem sido exposta por ser presa política. O problema não ocorreu em função do riso simplesmente (como se quiséssemos manipular as reações dos espectadores), mas em função de que alteração tão intensa se dava de maneira brusca, o que impedia que o espectador percebesse a situação apresentada em sua complexidade. Após verificarmos duas ou três vezes essa situação se repetir, optamos por trocar de lugar uma cena que ocorria à posteriori, que passou a servir como conexão menos brusca entre os dois momentos.

\section{2) Plano $B$}

Situação distinta ocorreu em relação a uma cena que envolvia participação dos espectadores. Quando a personagem Iara é morta enforcada, a atriz mantém essa posição de "morta em pé" - para inverter o sentido habitual, até que são convidados voluntários da platéia para movê-la de lugar. Uma vez que nem sempre há voluntários dispostos em todas as apresentações, é necessário que os atores tenham um 'plano B', uma opção para o caso de seu chamado não ser atendido. Após recusa de vários grupos de jovens em participar, Ana Maria Quintal resolveu a situação, tirando partido inclusive de certa ironia ao mandar a morta mover-se com suas próprias pernas: "Depois não venham me cobrar verossimilhança".

\section{3) Exclusão de cena}

Em outro momento de relação direta com o público, propúnhamos, no início do $3^{\circ}$ tempo, que pensássemos juntos o que identificávamos, ou não, em dias atuais que fossem "herança" dos chamados anos de chumbo. A ida à platéia era introduzida com esse argumento: apresentamos alguns fatos e dados históricos, mas é melhor pensarmos o presente a partir de um exercício coletivo. Claro que as reações eram as mais diversas: alguns davam opiniões variadas, outros grupos ficavam sem reação - então propúnhamos a leitura de um texto que dava mais subsídios ao debate, feita por um espectador, e, posteriormente retornávamos ao palco para finalização do espetáculo. A proposição era acender ali uma centelha de debate, construção coletiva de pensamento crítico, que seria depois, no debate propriamente dito, estimulada. Qual não foi nossa surpresa quando, numa apresentação para alunos do EJA de uma escola localizada na extrema periferia de São Paulo, onde os alunos e professores são bastante ativos em sua comunidade e o debate acerca dos problemas que os 
afligem são constantes, no momento dessa pequena abertura o debate se instaurou de maneira tal, que quase se tornou impossível a retomada da parte final da peça. Na verdade, optamos por abertamente explicar que ainda tínhamos duas cenas para mostrar e que, ao final, abriríamos novamente o espaço para a discussão, apesar da imensa satisfação que todos sentíamos naquele momento, por considerarmos importantes as opiniões finais para incrementar o debate. A partir desse dia, o terceiro tempo passou a ocorrer somente no palco, com a proposta de debate ao final, mantida.

\section{Participação da plateia - ajuda do espectador é solicitada para se mover a “morta” de lugar}
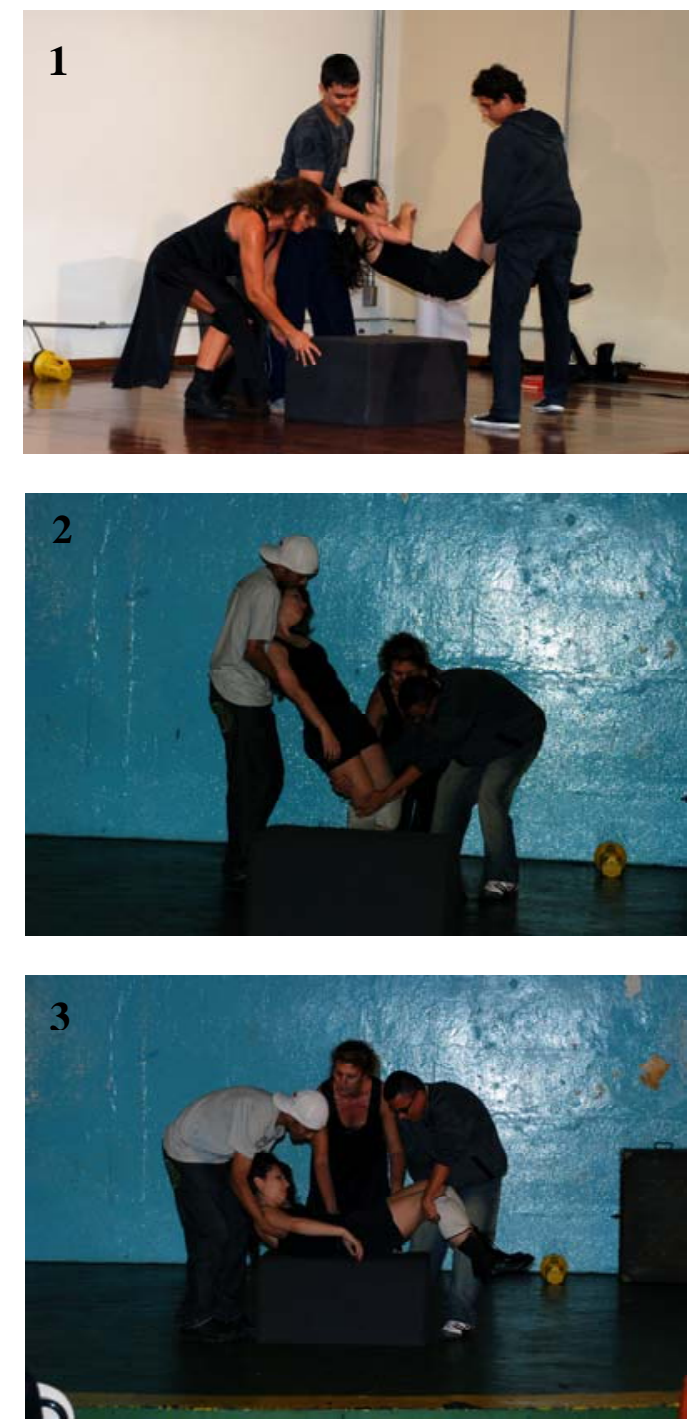

Sequência de fotos 24 :

Foto 1 - participação de alunos da ETEC Prof. Aprígio Gonzaga / São Paulo (março / 2011). Fotos 2 e 3 - participação de alunos da E.E. Prof ${ }^{\text {a }}$ Zenaide Vilalva de Araújo / São Paulo (abril / 2011).

Nas fotos: Camila Scudeler, Ana Maria Quintal e espectadores.

Crédito: Marisa Quintal. 


\section{Debates com o público}
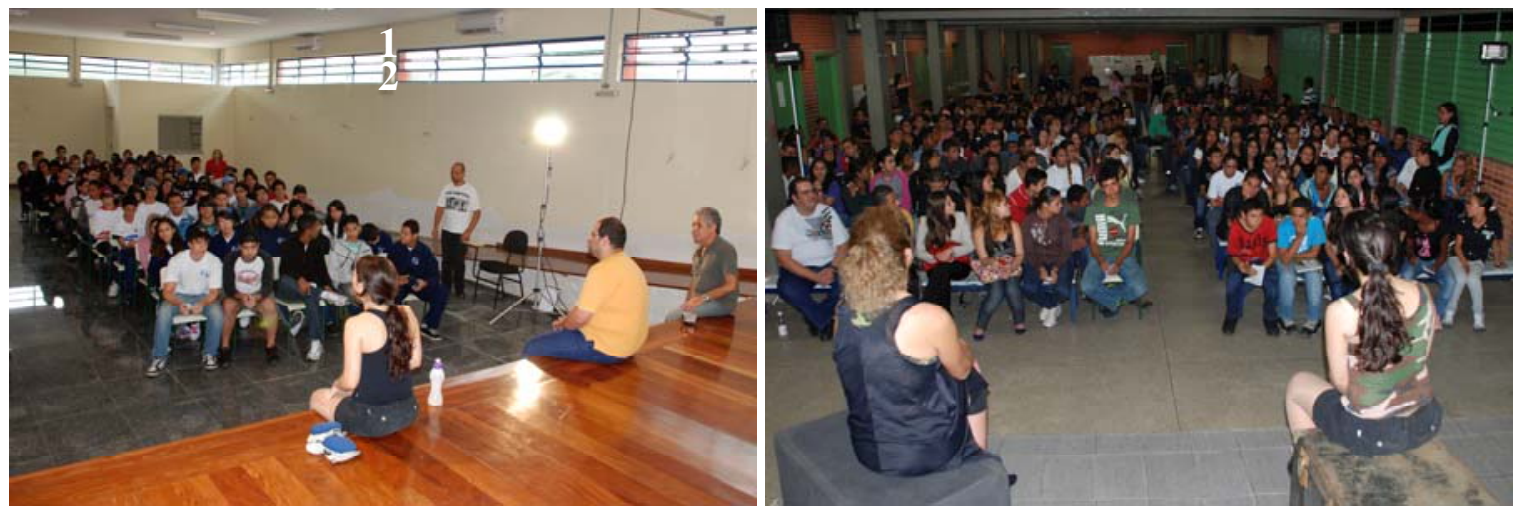

Sequência de fotos 25 :

Foto 1 - debate com alunos da ETEC Prof. Aprígio Gonzaga / São Paulo (março / 2011).

Na foto - (palco) Camila Scudeler, Luiz Soares e Sérgio Santiago e público

Foto 2 - debate com alunos da E.E. Prof ${ }^{\text {a }}$ Carmelinda Marques Pereira / São Paulo (março / 2011)

$\mathrm{Na}$ foto - (palco) Ana Maria Quintal e Camila Scudeler

Crédito: Marisa Quintal.

\section{Participação da plateia}

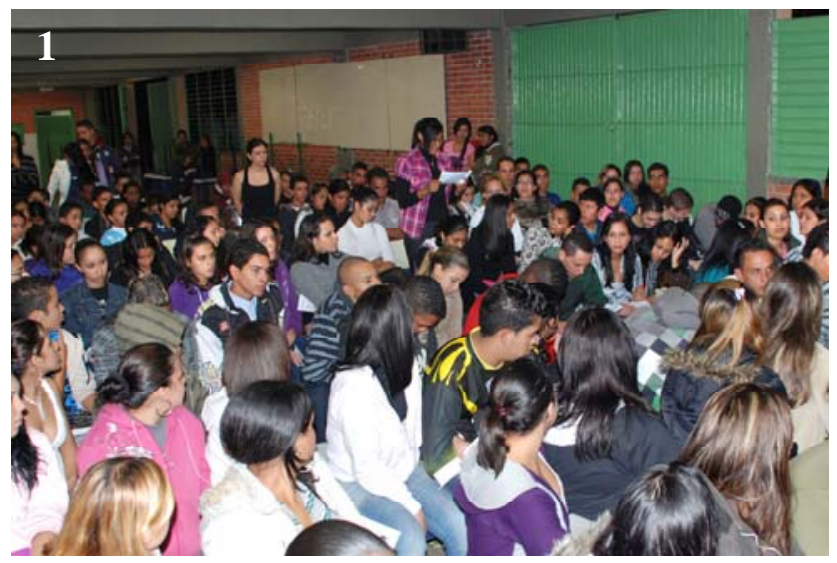

Cena de participação da plateia com intervenções: acabou sendo alterada após apresentação na E.E. Limoeiro III (São Paulo) uma vez que durante essa interrupção e motivado pelo clima de incentivo de participação, expressão, os espectadores acharam que o espetáculo já tinha terminado. Empenharam-se num amplo debate, que precisamos interromper em certa altura para podermos concluir a peça. Após essa experiência (muito prazerosa e marcante), optamos por incentivar o debate após a conclusão da peça, até para podermos juntos analisar a conjuntura depois de termos apresentado todos os nossos argumentos.

Sequência de fotos 26 :

Foto 1 - aluna lê trecho do livro $\mathbf{O}$ que resta da ditadura ${ }^{204}$ para incentivar o debate e ampliar elementos para argumentação.

Local: E.E. Prof ${ }^{\mathrm{a}}$ Carmelinda Marques Pereira / São Paulo (março / 2011)

Na foto - Camila Scudeler e público

Crédito: Marisa Quintal.

${ }^{204}$ TELES, Edson; SAFATLE, Vladimir (Org). O que resta da ditadura: a exceção brasileira. São Paulo: Boitempo, 2010. 


\section{CONSIDERAÇÕES FINAIS}

O processo aqui descrito foi responsável por ampliar em mim a consciência dos meandros da criação cênica, tendo a convicção de que a criação compartilhada enriquece os caminhos.

À luz do que apresentei nestas páginas, consolido a convicção no teatro como experimento estético social, no qual o aprofundamento da vivência coletiva (e, portanto política), faz reverberar novas possibilidades de compreensão do mundo em que vivemos. Os princípios estéticos que subjazem ao teatro têm em comum a concepção do homem como construtor de si, enquanto construtor da história e da sociedade, pelo trabalho.

A relação com o espectador sela esse ciclo de troca, construção e busca pela emancipação humana de todos os envolvidos. 


\section{BIBLIOGRAFIA}

ABREU, Luís Alberto de. Processo colaborativo: relato e reflexões sobre uma experiência de criação. $\mathrm{S} / \mathrm{R}$ (artigo não publicado).

ADORNO, Theodor W. Notas de literatura. Capítulo Engagement. Rio de Janeiro: Tempo Brasileiro, 1991.

ARAÚJO, Antonio. A Encenação no Coletivo: desterritorializações da função do diretor no processo colaborativo. Tese de doutoramento. ECA-USP, São Paulo, 2008.

ARTAUD, Antonin. O teatro e seu duplo. São Paulo: Martins Fontes, 1999.

BAKHTIN, Mikhail. Marxismo e filosofia da linguagem: problemas fundamentais do método sociológico na ciência da linguagem. São Paulo: Hucitec, 1981.

BENNETT, Susan. Theather audiences: a theory of production and reception. London: Routledge, 1990.

BENJAMIN, Walter. Magia e técnica, arte e política - Ensaios sobre literatura e História da cultura. São Paulo: Brasiliense, 1986.

. Documentos de cultura, documentos de barbárie: escritos escolhidos. São Paulo: Cultrix: Editora da Universidade de São Paulo, 1986.

BERTHOLD, Margot. História mundial do teatro. São Paulo: Perspectiva, 2001.

BONFITTO, Matteo. O ator-compositor: as ações físicas como eixo - de Stanislávski a Barba. São Paulo: Perspectiva, 2002.

BRAUN, Edward. Meyerhold - a revolution in theatre. London: The Bath Press, 1995.

BRECHT, Bertolt. Estudos sobre teatro. Rio de Janeiro: Nova Fronteira, 1978.

Diário de trabalho - Volume I 1938-194. Rio de Janeiro: Rocco, 2002.

BURNIER, Luís Otávio. A arte de ator: da técnica à representação. Campinas,SP: Editora da Unicamp, 2001.

CARVALHO, Sérgio de e colaboradores. Atuação crítica - Entrevistas da Vintém e outras conversas. São Paulo: Expressão Popular; Companhia do Latão, 2009.

CHAVES, Yedda Carvalho. Dissertação de mestrado. A Biomecânica como princípio constitutivo da arte do ator. ECA/USP, 2001.

V. Meyerhold: um percurso através do processo de incorporação - Traços de uma herança. Tese de doutoramento. No prelo. 
CHEKHOV, Michael. Para o ator. São Paulo: Martins Fontes, 1996.

COSTA, Iná Camargo. A hora do teatro épico no Brasil. Rio de Janeiro: Paz e Terra, 1996. . Sinta o drama. Petrópolis, Rio de Janeiro: Vozes, 1998.

; CARVALHO, Dorberto. A luta dos grupos teatrais de São Paulo por políticas públicas para a cultura: os cinco primeiros anos da lei de fomento ao teatro. São Paulo: Cooperativa Paulista de Teatro, 2008.

DALLARI, Dalmo de Abreu. O que é participação política. São Paulo: Brasiliense, 1999. DEBORD, Guy. A sociedade do espetáculo. Rio de Janeiro: Contraponto, 1997.

DORT, Bernard. O teatro e sua realidade. São Paulo: Perspectiva, 1977.

EAGLETON, Terry. Marxismo e crítica literária. Porto: Editora Afrontamento, 1976.

EATON, Katherine Bliss. The theater of Meyerhold and Brecht. Westport: Greenwood Press, 1986.

GARCIA, Silvana. Teatro da militância - A intenção do popular no engajamento político. São Paulo: Editora Perspectiva, 2004.

GASPARI, Elio. A Ditadura Envergonhada, volume 1. São Paulo: Companhia da Letras, 2002.

A Ditadura Escancarada, volume 2. São Paulo: Companhia da Letras, 2002.

A Ditadura Derrotada, volume 3. São Paulo: Companhia da Letras, 2003.

A Ditadura Encurralada, volume 4. São Paulo: Companhia da Letras, 2004.

GONÇALVES, Vanessa. Eduardo Leite Bacuri. São Paulo: Plena Editorial, 2011.

GONZALEZ, Rafael. GTE - Grupo Teatro Escambray (1968-1988). Manicaragua, 1988.

HARDT, Michael; NEGRI, Antonio. Multidão: guerra e democracia na Era do Império. Rio de Janeiro: Record, 2005.

JAMES, William. What's an emotion. [?]

KAYSER, Wolfgang. O grotesco- configuração na pintura e na literatura. São Paulo: Perspectiva, 1986.

LEACH, Robert. Vsevolod Meyerhold. Cambridge: University Press, 1993.

. Stanislavsky and Meyerhold. Bern: Peter Lang, 2003 
MARIA THAIS. Na cena do Dr. Dapertutto: poética e pedagogia em V.E.Meierhold: 1911 a 1916. São Paulo: Perspectiva: FAPESP, 2009.

MATE, Alexandre. Trinta anos da Cooperativa Paulista de Teatro - uma história de tantos (ou mais quantos, sempre juntos) trabalhadores fazedores de teatro. São Paulo, 2009 .

PATARRA, Judith Lieblich. Iara: reportagem biográfica. Rio de Janeiro: Rosa dos Tempos, 1992.

PAVIS, Patrice. Dicionário de Teatro. São Paulo: Perspectiva, 2003.

PAZ, Carlos Eugênio. Viagem à luta armada. Rio de Janeiro: BestBolso, 2008.

PEIXOTO, Maria Inês Hamann. A arte no cotidiano: consciência e autoconsciência. In: Anais III Fórum de pesquisa científica em arte. Escola de Música e Belas Artes do Paraná. Curitiba, 2005.

RAGO, Luzia Margareth; MOREIRA, Eduardo F. P. O que é taylorismo. São Paulo: Brasiliense, 1984.

REYES, Carlos José. La creación colectiva: uma nueva organización interna del trabajo teatral (1974). In: El Teatro Latinoamericano de Creación Colectiva. Ciudad de La Habana: Casa de Las Américas, 1978.

RIPELLINO, Ângelo Maria. O truque e a alma. São Paulo: Perspectiva: 1996.

ROSENFELD, Anatol. O teatro épico. São Paulo: Perspectiva, 2006.

ROUBINE, Jean-Jacques. A linguagem da encenação teatral. Rio de Janeiro: Jorge Zahar, 1998.

SCUDELER, Camila Ladeira. Criação do experimento cênico "a Mulher e o Cisne": o trabalho individual na amplitude da criação coletiva - um relato. In: SILVA, Armando Sérgio da (Org.). CEPECA: uma oficina de pesquisatores. São Paulo: Associação Amigos da Praça, 2010. p. 229-244.

SILVA, Armando Sérgio da. Oficina da essência. In: SILVA, Armando Sérgio da (Org.). CEPECA - Uma oficina de PesquisAtores. São Paulo: Associação Amigos da Praça, 2010.

TAKEDA, Cristiane Layher. O cotidiano de uma lenda: Cartas do Teatro de Arte de Moscou. São Paulo: Perspectiva: FAPESP, 2003.

TELES, Edson; SAFATLE, Vladimir (Org). O que resta da ditadura: a exceção brasileira. São Paulo: Boitempo, 2010. 


\section{Periódico}

REVISTA CAROS AMIGOS. O Golpe de 64: Edição dedicada à juventude que deseja conhecer em detalhes esse episódio da história política brasileira. Edição Especial 019 Outubro 2004. Ed. Casa Amarela.

\section{Vídeo:}

Meyerhold's Theatre and Biomechanics - A film by the Mime Center Berlin in collaboration with Gennadi Bogdanov / Item: Improvisation with mask and voice

\section{Palestras e Seminários}

Palestra proferida por Iná Camargo Costa ao Núcleo Arlequins da Cooperativa Paulista de Teatro, na União da Juventude Socialista (UJS) dia 12 de dezembro de 2008, cujo tema principal era: Meyerhold no processo revolucionário russo / Ser ou não ser comunista.

Palestra de Iná Camargo Costa e João das Neves intitulada "O teatro épico no Brasil", durante Ciclo de debates de Dramaturgia Crítica promovido pela Companhia do Latão no dia 29 de abril de 2010, na sede da Companhia, na cidade de São Paulo.

Seminário com Béatrice Picon-Vallin durante a oficina: Iniciação à biomecânica ministrada por Alexey Levinskiy e Béatrice Picon-Vallin durante o ECUM - Centro Internacional de Pesquisa Sobre a Formação em Artes Cênicas, Belo Horizonte de 23 a 30 de outubro de 2010.

\section{Sítios da internet}

GRIGOLO, Gláucia. O ator do futuro: por Meyerhold. Artigo disponível no site: http://www.portocenico.com.br/artigos/O_ator_do_futuro_por_meyerhold.pdf

Acesso em: 20 dez. 2011.

COSTA, Iná Camargo. Filhos da indigna Dita. Artigo disponível na página: http://geracaoai5.blogspot.com/p/filmes-que-temos-visto.html Acesso em: 10 jul. 2011.

Entrevista com Robert Kurz disponível no site http://www.ihuonline.unisinos.br Acesso em: 21 ago. 2009.

$<$ http://doloresbocaaberta.blogspot.com> Acesso em: 02 ago. 2011.

$<$ http://www.eca.usp.br/prof/iazzetta/tutor/acustica/introducao/som.html $>$ Acesso em: 18 dez.2011.

$<$ http://engenhoteatral.wordpress.com> Acesso em: 02 ago. 2011.

$<$ http://marighellavive.blogspot.com/> Acesso em: 20 jul. 2011.

$<$ http://www.sergiodecarvalho.com.br> Acesso em: 10 ago. 2011. 


\section{Filmes}

- A Culpa é do Fidel - direção: Julie Gravas (2006)

- A Idade da Terra - direção: Glauber Rocha (1980)

- A Onda - direção: Dennis Gansel (2008)

- $\mathrm{ABC}$ da Greve - documentário projeto de Leon Hirszman (1990)

- Adeus, Lênin! - direção: Wolfgang Becker (2002)

- Batismo de Sangue - direção: Helvécio Ratton (2007)

- Bom dia, noite - direção: Marco Bellocchio (2003)

- Cidadão Boilesen - documentário/direção: Chaim Litewski (2009)

- Condor - documentário/direção: Roberto Mader (2007)

- Daens - Um grito de Justiça - direção: Stijn Coninx (1994)

- Deus e o Diabo na Terra do Sol - direção: Glauber Rocha (1964)

- Em Nome da Segurança Nacional - direção: Renato Tapajós (1984)

- Entreatos - documentário/direção: João Moreira Sales (2004)

- Estado de Sítio - direção: Costa Gravas (1973)

- Greve - direção: João Batista de Andrade (1979)

- Hércules 56 - documentário/ Silvio Da-Rin (2006)

- Jango - como, quando e porque um presidente é deposto - (1984), Direção Sílvio Tendler

- Lamarca - direção: Sérgio Rezende (1994)

- Meu Irmão é Filho Único - direção: Daniele Luchetti (2007)

- O Velho - direção: Toni Venturi (1997)

- Os Sonhadores - direção: Bernardo Bertolucci (2003)

- Tempo de Resistência - documentário/direção: André Ristum (2003)

- Três Irmãos de Sangue - documentário/direção: Ângela Patrícia Reiniger (2006)

- Vlado, 30 anos depois - documentário/direção: João Batista de Andrade (2005) 
ANEXOS 
ANEXO A- FICHA TÉCNICA DO ESPETÁCULO Os filhos da Dita

Texto:

Dramaturgia:

Direção:

Elenco:

Fotos e Artes Gráficas: Edson Frank

Figurinista:

Assistente Corporal: Bruno Garcia

Treinamento de Biomecânica: Yedda Carvalho Chaves

Consultor Musical: Gregory Slivar

Assistente de produção: Luiz Soares

Produção DVD projeto: Danielle Agostinho

Produção: Marisa Quintal

Os filhos da Dita

Éjo de Rocha Miranda

Ana Maria Quintal

Sérgio Santiago

Ana Maria Quintal

Camila Scudeler

Éder Lopes

\author{
Arlequins \\ Cooperativa Paulista de Teatro
}




\section{Os filhos da Dita}

de Éjo de Rocha Miranda e Ana Maria Quintal

\section{Saguão}

Mulher parindo numa prisão de vidro

Narradora - Teatro, tudo tudo teatro! 0 que haveria de igual naquele ontem e no hoje nosso de hoje-em-dia. 0 que é que havia lá que aqui também há? Eram tempos sombrios de ditadura militar e o nosso espetáculo, o Marotinho, para ser liberado os censores fizeram vários cortes. Essa experiência com a censura vivida pelo Arlequins, e por tantos outros artistas parece perdida no tempo. Hoje a censura foi substituída pela ditadura do mercado: cultura é subproduto, o que interessa é entretenimento e dinheiro, gerar lucro e ponto final! Portanto quem não se enquadrar nessa nova ordem não vai dispor das condições mínimas necessárias para desenvolver o seu ofício, o que fazer? 0 Arlequins preferiu se responsabilizar por construir suas escolhas e isso tem um preço: dispomos apenas de meios pobres, (procura) de meios precários, para contar nossas histórias. Esse teatro se constrói na imaginação de seus criadores e dela se apropria. E por isso resolvemos enriquecê-lo com outros elementos: a imaginação de vocês. Não pra imaginar o inimaginável, mas pra raciocinar como se a vida continuasse sempre. Contamos com sua participação. E já que estamos juntos nessa. Relaxem. Gostaríamos que vocês se divertissem como nós nos divertimos. Vem vamos embora!

Prólogo

Na entrada, uma bandeira: "não vire à esquerda"

um cravo no centro do palco

invasão de coturnos orientados numa mesma direção e sentido 
Narradoras (em cânone) - eu sou de um tempo que, - assim - quando alguém falava já não era fala de gente era fala da "sociedade civil"

eu sou do tempo em que a tragédia e a dor já tinham se transformado em discurso

a década perdida e a dor - ridícula - a ser esquecida

eu sou do tempo em que o próprio tempo ia acabar, num nunca mais ser de novo qualquer coisa e qualquer coisa ia acabar antes da noite que ia descer, que ia descer

Eu sou do tempo feito de mais valia

Narradora - Esses olhos são seus?

a realidade é irrecuperável

mas ficam as marcas

ficam(os) filhos

os filhos da Dita!

\title{
$1^{\circ}$ tempo
}

\section{Coturnos}

Narradora - $1^{\circ}$ de abril/ 1964/ Rio de Janeiro/ Av. Brasil, poderia ser qualquer outra. Um clima apressado, opressivo. Tanques nas ruas, oficiais de óculos escuros gritam com seus soldados.

\section{o Golpe/ Canção do Expedicionário}

\author{
Você sabe de onde eu venho \\ Venho do morro do engenho \\ Das selvas dos cafezais \\ Da boa terra do coco \\ Da choupana onde um é pouco \\ Dois é bom três é demais...
}

P1

Sargento A - Detenham o movimento das tropas/ não vamos avançar, por enquanto

Venho das praias sedosas

P2

Das montanhas alterosas

Sargento C - Cessar o avanço. Espalhem-se

Dos pampas do seringal

Das margens crespas dos rios

P3

Cabo A - Parar, por que???? 
P4

Dos verdes mares bravios

Cabo C - Coluna de blindados, alto!

P5

Da minha terra natal

Cabo A - Senhora, não ultrapasse, é área militar. A senhora é louca?

Por mais terras que eu percorra

Não permita Deus que eu morra

P6

Sem que eu volte para lá

Dita Louca - (passou a barreira) ... mas ela entrou que eu vi. Tá tendo um filho a desgraçada. O filho já tá saindo pela barriga. E o povo levando ela pra dentro da guerra. É guerra não é. Eu sei. Eu conheço. Desde antes... (passagem do bastão)

Sem que leve por divisa

Esse "vê" que simboliza

A vitória que virá

Nossa vitória final

Que é a mira do meu fuzil

A ração do meu bornal

PAULADA/GOLPE

A água do meu cantil

As asas do meu ideal

PAU DE ARARA

A glória do meu Brasil!

a - (off) mantenham os congestionamentos.

cb Ladeira - Coronel tem uma mulher aí dando a luz - não sei nem se já num deu

cb Quintal - consegui parar o trânsito do lado de lá também... maior congestionamento!

cb Ladeira - Esse coronel precisa fazer um curso de trânsito: como é que nós vamos chegar logo se ele manda a gente provocar esse puta congestionamento

cb Quintal - mas quem é que quer chegar logo

cb Ladeira - uai! nós, ué...

cb Quintal - ce deixa de ser besta. Os oficiais não estão querendo brigar entre si não. Hoje mesmo eles se 
encontram e vão lá tirar o presidente na bala. Então é melhor se encontrar aqui em baixo mesmo, né

Narradora C - 0 Gal. Mourão decidiu descer a serra com suas tropas para depor o presidente Jango. 0 golpe ia acontecer de qualquer maneira, mas a besta do general antecipou em dez dias. Os americanos ainda estavam a caminho.

cb Ladeira - eu heim!... e como é que... você fica sabendo disso... dessas coisas todas -/não é comunista não?: é?! Sabe que tem até general...

Narradora A - ameaça comunista - foi a desculpa usada para dar o golpe

cb Quintal - ...cabo Ladeira ...acho que você... - nunca! vai chegar a sargento...

cb Ladeira - também, diz que é tudo amigo do Goulart... Afinal, de que lado você está?

cb Quintal - Não sei, ainda não recebi ordens!

\section{A Louca}

\section{Entra o sargento puxando a louca por uma corda}

Sargento - trata-se de uma louca, major. Fui eu que amarrei ela assim, não senhor, posso sim, é só mandar ela mesma ficar segurando (dá a corda pra louca) (sussurrando) Ela é louca

Dita Louca - (canta) Sou louca! Sou louca por você... Sou louca/ (Tom) Sabe por quê?! Louca porque cada vez que eu rodo o mundo dá meia cambalhota e tudo volta e reviravolteia...eu sou a dita cuja. Sim, sou louca. Louca pelo poder. Poder ser dona de coisas e todas. Todas as coisas. São para meus filhos. Não para todos. (cantarola) Já podeis da pátria filho ver contente a mãe gentil... Não. Não. Não são para ser contabilizadas, nem mortes, nem dor. 0 que há é política. E política não é o poder: mas é muito perto do poder. Então fica um pode. Não-pode. Que o poder diz, aos berros poderosos: - Pode o que eu puder... Não pode o que eu não quiser. E fica o dito pelo bendito e pelo maldito 
c - ...uma louca! Soldado! Uma louca! ...amarrada pelo pescoço? Faça o que quiser... fuzila, esgana, só não me enche o saco!

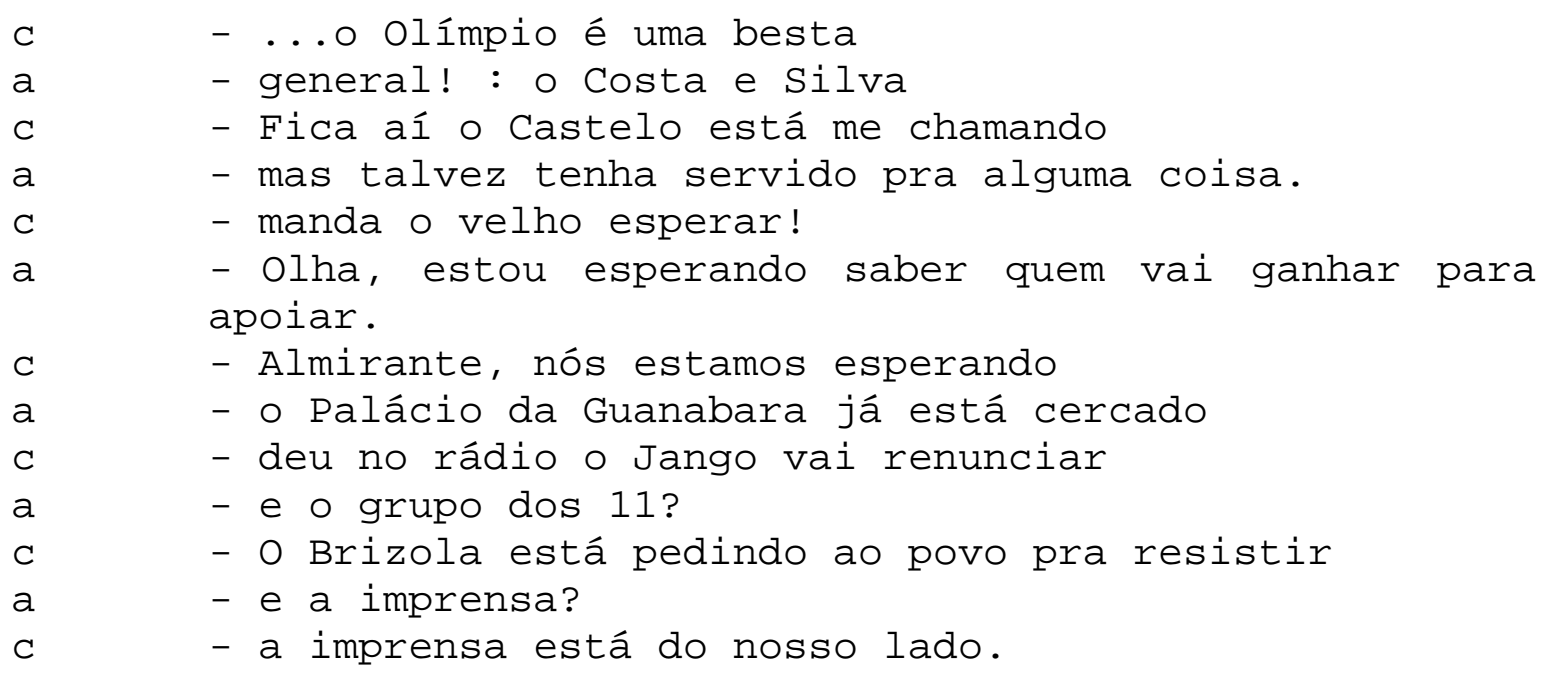

\section{voz americana ao telefone}

- Yes, Operation Brother Sam, in progress. - (corte narrativo informa: uma força-tarefa americana para garantir a deposição do Presidente Jango) (misturando inglês e português) Essa guerra é contra um "inimigo interno". Special forces, os Green Berets para lowintensity wars... Pode não haver outro momento tão bom como esse. Ok

(off) - o dispositivo militar do Jango, tem que acionar o mais rápido possível. Senão não dá mais!...

C - no dia em que se descobriu

como num primeiro de abril

o tudo que se mentiu,

0 tudo que se mentiu

foi mentido de novo.

Primeiro de abril!

\section{Jango}

Gen Kruel - Presidente João Goulart, feche a CGT, a UNE, demita esses "comunistas" do governo que eu ponho minhas tropas na rua, agora.

Jango - A crise que se manifesta no país foi provocada pela minoria de privilegiados que vive de olhos voltados para o passado e teme enfrentar o luminoso futuro que se abrirá à democracia pela integração de milhões de patrícios... 
1 - 0 presidente Jango ainda estava em território nacional. Mesmo assim: Declaramos vago o cargo de presidente da República!

Jango - Ser ou não ser.

Ser ou não estar

Estar ou não ser.

Estar ou não estar(?)

1

- esqueça... esqueça...

Black out

\section{Lanternas}

Helicóptero. o foco da lanterna explode em várias direções. Perseguição. Informação codificada.

Iara - já se foram os meus dias de tortura. TORTURA... Bem! ...agora é isso aqui... Presa nesta cela imunda, úmida, nojenta... E os dias passando. Nenhum contato e é isso: fico aqui, construo sombras, e me relaciono com elas... Eu mesma, nem sei...

Tempestade. Raios. Ruídos. C prepara a procissão da História

A

- ...deixa passar toda a tempestade do ódio, contra a opressão. Do rancor pelas perdas, da dor desmerecida de perdedor... desde o princípio, é sempre, o espaço e a gravidade. A luz é o espaço.

A

- o fardo do tempo torna pesada a memória... Um momento histórico conturbado: auge da Guerra Fria, revolução vitoriosa em Cuba, o assassinato de Kennedy, esses acontecimentos provocaram um estado de histeria anticomunista nas classes dominantes...

Procissão:

C $\quad-1954$

a - os golpistas foram frustrados pelo tiro no coração de Vargas

c $\quad-1955$

a - nova tentativa: JK não teve maioria absoluta nas eleições

c $\quad-1961$

a - após a renuncia de Jânio tentaram de novo e só permitiram a posse do vice Jango inventando um parlamentarismo de ocasião

a $\quad-1964$

c - Vitória! após uma intensa campanha anticomunista com o apoio da sociedade civil o golpe vitorioso 
Ritmo claro-escuro. Fogueira

c $\quad$ - os golpistas insistem em encobrir sua responsabilidade. Nós não demos o golpe.

a - Fomos obrigados a dar o contragolpe pelo povo brasileiro.

c - Queríamos preservar o regime democrático

a - e para preservar a democracia a destruíram. (atirando livros na fogueira) Material subversivo

c - pequeno-burguês conspira, conspira, não toma uma medida de organização, fracassa tudo, todo mundo é responsável, menos ele.

a - e na imprensa(02 de Abril de 1964): Fugiu Goulart e a democracia está sendo restaurada. Atendendo aos anseios nacionais de paz, tranqüilidade e progresso, as Forças Armadas chamaram para si a tarefa de livrar a Nação dos trapos vermelhos.

C

- Caminhos se bifurcam, é claro. Mas caminhos também se entrecruzam. E tendo entrecruzado a possibilidade do Brasil ser o assim ou o assado

a - foi o assado que ficou e assim sendo o que era pra ser, não seria... Com todos os não, que o seria tem

c

- Procura: procura o quê?

a

- eu queria fazer teatro assim, sobre o mundo que virá, mas aí, pensei, sei lá, vou fazer sobre esse mundo mesmo, que ainda nem virá, mas veio.

C

- nascida teatro está aqui ...e agora conosco procurando também esse lugar onde está guardada a mesma pergunta:

"Como foi que chegamos aqui?"

a

- Queremos reconstruir o nosso passado (não meu não seu) dele somos ...filhos. Filhos da Dita

\section{o Coro Dodecafônico}

Cantam - ou ou é ou é ou é é ou...

ou é ou é ou é é ou...

ou é ou é ou é é

E o e o e e o e o e e o e o e o eeeeee...

- Filhos da pátria Brasil! Filhos da dita

Filhos da dita. Filhos da pátria, filhos

Filhos da pátria Brasil! Filhos da dita 
- ou ou é ...
ou é . é . ou

Narradora - A lagoa dos sapos verdes.

Diálogo de 2 sapos (sons)

Sapo 1 - Rabit! Qurec!

Sapo 2 - Frog! E aí? Qurec! Frog!

Sapo 1 - Rabit! Qurec! Eu bato!

Sapo 2 - Eu arrebento!

Sapo 1 - Eu bato!

Sapo 2 - Eu arrebento!

Sapo 1 - Dops!

Sapo 2 - Con dor!

Sapo 1 - Dops!

Sapo 2 - Fleury!

Sapo 1 - Pega!Fleury!

Sapo 2 - C

Sapo $1-$ C

Sapo 2 - C

Sapo 1 - Dói!

Sapo 2 - Codi!

Sapo 1 - Oban!

Sapo 2 - Oban!

a - Dizem que eu sou de direita, mas isso é uma injustiça. Nunca fui e não sou de direita. (pausa) Eu sou de extrema direita.

C

- A esquerda é boa para duas coisas: organizar manifestações de rua e desorganizar a economia. 
a

C

a

C

\section{Humilhação do trabalhador}

$C$

- garçom desgraçado, eu te arrebento. Vou deixar o desgraçado se levantar, mas vai ter que pagar pedágio

o Trabalhador - E aí eu paguei, né... A classe trabalhadora ficou sozinha até o último momento.

\section{CRISE}

Narrador $c$ - Um retrato tão grande não poderia ser feito só com essas fichas. Prá alguma coisa a dor serviu. Alimento de algum mal? Qual? o mal. Qual?! temos que ir lá

Narrador a - Tá. Nós vamos seguir você.

Iara/narradora/Iara - (girando marcialmente $o$ bastão se pergunta narrativamente. A fala não acompanha a marcialidade a não ser em alguns momentos finais em que o físico puxa o vocal. Está apenas preparando) É... penso assim... esse texto... se é a Iara pensando nisso... e agora ela já ta aqui... (pausa maior) presa... falando... alguma coisa... assim na minha cabeça...não é alguém batendo nela, é a Iara. Com raiva, pensando nisso aqui... ela bateu e aí ela apanhou... é ela: Iara na prisão. (pausa.como que responde)Não! (continua) Acho que o público nem precisa saber que o nome dela é Iara. Isso serve pra quê? Pra quê?!... Mas quando ela tá aqui, pra descer, é que diz então:(fala "narradorosamente") Trago suspiros guardados, graças à brutalidade dos nossos tempos que não permitem nem a infelicidade. Só a luta e a dor. Ninguém me viu desembarcar na unânime noite, 
mas, estava ali, como aqui estou, e onde estivesse, ouviria sempre esse, assim, lamento longo. Que arrepia a pele de quem ouve. Sabia: eu sabia: o que era. A dor: das mortes, dos sofrimentos, de toda essa trajetória sangrenta dessa raça de macacos assassinos. Assassino: genocida.

A - Esses olhos são seus?

Iara - (desliza "pra dentro" da personagem)...quando eu tinha seis anos de idade, não pude ver o fim da festa de São João... E de meus sonhos de igualdade humana vi nascerem covas que jamais verei serem descobertas e crânios esfacelados no exílio. E dor de nunca mais. E o que ia ser não vai mais. Choro porque não era pra ser assim. Choro porque foi assim.

\section{Missa Negra}

a

- ou é ou será ou seria

místico caminho se abria

que defendia a democracia

da própria democracia

C

- mística burguesia

de tortuosa contradição

numa mão a constituição

e na outra ditadores armados

\section{Exorcização}

c - direito político! deixa esse corpo que não te pertence! Chega. Já tá bom
a - só isso?
c - era só um aquecimento pra missa
a - Missa?
c - é pra missa negra.
a - Missa Negra!

Missa Negra

Narradora c - sexta feira, 13, dezembro, 1968, ditador presidente: marechal Arthur da Costa e Silva

o marechal - hoje ou a revolução continua, ou a revolução se desagrega. (pausa) vinte minutos, para que todos leiam 0 ato institucional $n^{\circ} 5$. (aplausos)

Narradora $c$ - Todo ato institucional que modifique a Constituição existente, é um ato revolucionário. - Às favas, senhor presidente, com todos os escrúpulos de 
consciência. - Aprovo o texto com bastante
satisfação.

C

- sim, senhor presidente

a

- CADEIA... nacional

\section{Concomitante:}

Narradora c - Fica instituído:

- fechamento do Congresso Nacional

- intervenção nos estados e municípios

- cassação dos mandatos políticos

- proibição de reuniões

- suspensão do habeas corpus

- civis julgados por juntas militares

Narradora a - Essa noite durou dez anos e dezoito dias

Aí sim começa "oficialmente" a ditadura

aí sim, com a ajuda da sociedade civil o terror se instaura

aí sim, com brutal repressão todas as liberdades

individuais foram suprimidas

\section{Diagonal da equilibrista}

Narradora a - quero convidar-vos para velarmos juntos não por essa ou por aquela democracia - seria injusto - mas por todas as democracias que ficaram sem seus povos. (pegando o guarda-chuva) Deixai aqui fora toda esperança ó vós que entrais

0 Milagre

Templo dos Contemplados

C

a

C

- (canta: introdução de pra frente Brasil)

- O Milagre brasileiro ocorreu entre 1968 e 1973. Não se conhece o milagre se não se conhecer os contemplados. Senhoras, senhores!: 0 TEMPLO DOS CONTEMPLADOS

- (canta) 90 milhões em ação, pra frente Brasil, do meu coração. Todos juntos vamos, pra frente Brasil salve essa nação...

Contemplados - 0 Brasil é uma ilha de paz, num mundo tumultuado. É um milagre. Ele ser nosso. É um milagre ele produzir tanta coisa. Isto só acontece em economias desenvolvidas:

- a economia cresceu em média $11 \%$ ao ano

- o PIB aumentou 
- a inflação se estabilizou abaixo dos 20\%

- aumentou a produção industrial

- obras faraônicas

- crescimento da indústria automobilística

- sesquicentenário da independência do Brasil

- governo arrecadou mais impostos

- as exportações cresceram

- as importações cresceram

C

- (cantando) De repente é aquela corrente pra frente, parece que todo Brasil deu a mão, tototototototodos ligados na mesma emoção, tudo é um só coração...

Mulher (com a geladeira) - Ela é minha. Eu, sou dona, sou proprietária (pausa de tensão) dessa geladeira! Tão limpinha, tão branquinha! Sabe o que tem dentro? (pausa tensão) Nada. Mas quando... (devaneia) um dia, eu for rica. Assim, rica que... nem sei, assim muito rica... Sabe o que vai ter dentro?

Geladeira - Fala, ô, proletariazinha metida a besta

Mulher - Eu, heim! Uma geladeira que fala...

Geladeira - Vê se deixa de ser besta.

Mulher - Besta! eu?

Geladeira - Você.

Mulher - bom... (meio se conformando) se você diz... Eu não vou ficar aqui discutindo com uma geladeira.

Geladeira - Eu sei que você me ama

Mulher - Amo sim

Geladeira - (barulhos de motor, engrenagem...)

Mulher - (satisfeita) É isso eu gosto quando você faz assim

Geladeira - (continua os barulhos)(algumas palavras em inglês: Yes, honey, Darling, come suck my dick you, Mother fucker, Yes, come, fuck me, Yes!)

Mulher - Ela fala inglês!

Geladeira - Yes

Mulher - Vem me possui. Sim. Sim. Sim. 
Geladeira - Impossible, honey. Impossible!

Mulher - por quê?

Geladeira - porque eu sou cria sua

Mulher - minha filha!...

Geladeira - deixa de melodrama. Nossa relação é apenas material

Mulher - Material!? (fim da novela)

Narradora a - o país vai bem, o povo é que vai mal. Essa gigantesca máquina. Verdadeiro milagre... Trabalho barato e importação "um pouco cara" mas de objetos que tornam a nossa vida tão milagrosamente maravilhosa. É um milagre...

c - (cantando) Todos juntos vamos, pra frente Brasil, Brasil, salve essa nação...

Narradora a (continuando) - Entram vidas. Saem mercadorias.

- Trabalho empacotado para vender.

- Não interessa o que vende, nem o que compra.

c - nós construímos, além do Brasil grande, a única ditadura que aposenta seus ditadores, com direitos e tudo... ... água de coco aqui, positivo

coro - cantam

é a ditadura

que eu sempre quis

Eu não sou livre

mas eu sou feliz

Jogo de cartas marcadas

A - ó... Tá aqui...: (gesto de jogar as cartas na mesa) Seus três padres torturados por um tenente morto a pauladas

C $\quad-2$ guerrilhas na selva e 800 pãezinhos na Ribeira... pelos atos de 1 a 5

A - Boilesen por Bacuri

C - Filho da puta!

A - Quantos você tem aí? 
A $\quad-492$

C

- 4 embaixadores seqüestrados. Um, inclusive, americano, por uma copa do mundo

A $\quad$ - Tricampeã!?!

C - Seus ditadores ridículos por nossos heróis épicos

A $\quad-$ Infeliz

C - - do país que não tem heróis

a - nos industrializamos sob botas - coturnos. E quando continuamos a produzir... continuamos a produzir miséria, junto com o minério e outras comodidades

\section{Alameda Casabranca}

\section{Porões da ditadura. Alameda Fatal}

Iara - que a paz esteja conosco. Mas não a paz dos cemitérios. Não a paz da dor! Aqui, neste cantinho, me extinguindo, alguém vai saber que eu existi. Acocorada... porque me acocoraram. Doída. Porque me fizeram doer. E a dor - pior - não não é só a dor material que dói como um choque elétrico no $\mathrm{cu}$ - que faz a dor parecer ridícula. Não. Dói mais como dor de estar perdendo um mundo.

A canta - As horas pela alameda/ Arrastam vestes de seda/Vestes de seda sonhada/ Pela alameda alongada

Marighela

A atravessa o palco com a corda pela frente de Iara, como se depositasse restos

Narrador - A direita matou você. Exatamente o momento da emboscada. Corinthians versus Santos no Pacaembu um clássico. Dispositivo armado: homens escondidos, o famigerado delegado Fleury de tocaia. o alvo na mira: fogo! Morreu Marighela... Morreu Sonia... Morreu Lamarca... Bacuri... Osvaldão... Diná... Antônio... Maria... Marcos...

\section{0 tempo}

Fantasmas 
C sai da última tortura nos porões. A repetição do cai-e-selevanta-sobre-um-braço.
Narrador c - O Milagre é o templo onde se ergue o nosso orgulho acumulativo. Tem pequenos defeitos... (procura longamente) ...estruturais. É... esse... barulho... aqui de baixo... nos porões. São gritos que só uma dita muito bem sucedida em seu furor destrutivo poderia abafar. Estrangular.

A canta - As horas pela alameda... (no fundo do palco, camarim, constrói a Dita)

Iara - (resmunga)As horas pela alameda... (Enquanto $\boldsymbol{C}$ "inventa" Dita)...você é real porque minha vontade quer. Mesmo aqui - lambendo feridas que não querem cicatrizar, não quero as faces animalescas dos que nos torturam. De animais andamos fartos/ ...a humana, a mais dignamente humana face, coloca: coloca e vem me dizer. Vem! Do inferno que te pariu. Vem! Vem! Vem porque eu preciso. Preciso falar com alguém. Já que mataram os meus amigos. Vem. Inimigo, vem. Vem me dizer o nome maldito da tua razão. Vem! E diz! 0 que é que te fez.

Dita - Você quer, minha filha. Vou lhe mostrar meu corpo desnudo de mãe, em carne viva.

Dita amarra $C$

Iara - Carne morta. Tira teus eura teus neura... tira tudo o que quiser. Mas não tira. Não queira tirar essa covardia, que é bater quando se está em maioria.

\section{A joga C dum lado pro outro figuras de dominação}

\section{Iara - Assassino! (repete)}

Dita passa a máscara para $C$. Construir um enforcamento lento. Do Herzog.

Desconstruir Herzog. Tirar as cordas.C no IML. Lavagem do cadáver. Relações pietá. Ação e fala são desconexas.

Dita - Não adianta nem tentar: me esquecer. Ah ah. Não! Quem se esquece de você sou eu. Ah Ah Estúpidos! Meus filhos! Quero que vivam para sempre, mas o que melhor sabem fazer é morrer para sempre.

Alguns não deixam nem história. 
Passam sugados sem saber nem do sim nem do não. Estúpidos!

\section{A conclama a platéia a participar.}

Dita - Por favor, preciso da força, do trabalho, de dois voluntários. Preciso dessa mão de obra excedente. Por que a relutância? Vamos lá. Ao trabalho. (ajudam a levar $\boldsymbol{c}$ até a maca) Aplausos. Os aplausos são sua paga! Eu chicoteio, por amor, minha intenção é educar filhos preguiçosos, em nome do progresso.

(se acaso ninguém ajudar: Dita para $C$ - Então vem, vem com as suas próprias pernas. (para a platéia) Depois, não venham exigir verossimilhança.)

Dita - (Tom) Não! Não! Não! Não fui eu quem inventou a dor. Meus filhos foram assassinados, muito antes, muito antes deles também começarem a matar. Eu não queria que meus filhos soubessem, que a herança não é tédio e desamor. Pesa mais: é barbárie. Vaga de paixões humanas, antes da humanidade. Minha filha! Acorda! Joga tua vida na cara da vida: vive.

Iara - Viver pra que?

Dita - pra mostrar que a vida, como a vida tem que ser, é viver pra esse modo de ser: Ser assim, que nem se é: indo e vindo do trabalho, que não é um divertimento feliz, mas felizes os que o possuem. Um modo de ser que é obrigatório. Quem não o aceitar tem a "alternativa" de ser massacrado. E não perde por esperar. Um modo de ser que espera, pra não perder. E perde, só, a vida. Que também não é lá essas coisas.(Tom) Que morte é essa que nos faz conversar?

Iara - A morte do teu sistema de pilhagem, morte da tua moeda, teu capital, morte do teu trabalho morto. Construindo a morte do homem

Dita - Manifeste, o seu descontentamento. Manifeste. Nós aqui continuamos com as condolências. E condolências ou sem dolências ganhamos. (pausa) Ganhamos a guerra contra vocês. Ganhamos e vocês se retiraram com arrotos de insolências. Ganhamos e desde então colocamos a história no lugar. Tenho saudades dos tempos antigos. Acumulávamos. Com muito suor, às vezes com sangue. Mas sempre heroicamente. E desse heroísmo construímos o nosso 
indivíduo que hoje percorre a terra como um tiranossauro rex: Vencedor!

Iara - Canibais!

Dita - Chega! Não se manifeste mais, eu lhe peço. Deixa eu continuar (procura) hum: onde estávamos:

Iara - Acumulando...

Dita - heroicamente acumulávamos a riqueza que ia fazer o mundo moderno. Quando a liberdade moderna chegou com clarões atômicos queimando nossos rostos. Vi, como meus filhos viam espantados essa nova aurora do deus capital, maior entre os maiores, e sua filha dileta: a mercadoria.

Uma mãe! 0 mundo é uma grande teta. As vezes duas... As vezes mais... As vezes um tetal, pra ser mamado!... Mamar é amor! Agora: tem uns que mama mais, outros que mama menos. Assim. Gente. E gente é assim. Não é igual. Então fica um zumzumzum na minha cabeça. E eu ouço: como se fosse eu mesma que falasse: "ordinária". Cadela ordinária! Você pare seus filhos pra que? Eu digo: Ora vá se cata no catuê do seu catitu. Meus filhos - é pro mundo, que pra vida se nasce de tantas formas. Uns vão ser rico, poderoso, vão ter tudo e outros não. Não vão ter nada e ser um fudido e morrer com os dentes arreganhado. Liberdade, igualdade, fraternidade! (tom) Eu não queria ter machucado você, mas era guerra. Então eu peguei sim, suas unhas, e arranquei. Tenho tristeza de que isso tenha sido necessário. (pausa) 0 hino! Não sei falar sem o hino; pior; não sei pensar sem hinos. (canta) Dos filhos deste solo és mãe gentil! (tom) Queriam ordem: ordem há. Queriam progresso: olha só! Agora, queriam que viesse sem miséria. Queriam que viesse sem dor! Queriam que viesse com justiça!... Ora. Alguma coisa tem que se perder: mas eis aí: ordem e progresso (repete várias vezes) Ordem, progresso!

ORDEM/PROGRESSO

Uma corda é esticada na diagonal fundo/frente do palco sobre a cabeça das atrizes

A

- Por uma questão de ordem e em nome do progresso, gostaríamos que todos vocês visualizem essa diagonal - a diagonal do acordo - ela começa na década de oitenta e vai até os dias de hoje. Um acordo na corda que nos conduz, tão de acordo pela ordem e pelo progresso. 


\section{Início da diagonal da bandeira}

A

c

A

C

A

Seleção. DERROTA. Jogadores cabisbaixos. Um disfarça choro

C

a

C

a

C

a

C

a

C

a

C

\section{Na diagonal da bandeira}

$\boldsymbol{A}$

- Vamos lá: abertura política mas de forma lenta, gradual

C

- e segura... Onde foi que eu deixei meus olhos?

- Abertura política. É pra abrir mesmo. Quem não quiser que abra, eu prendo e arrebento!

- conseguimos inverter alguns papéis mas andamos amarrados à mesma corda

- logo que vi me veio a certeza... certeza absoluta: foi essa essa! Essa a corda que enforcou Tiradentes. Isso muito antes dele ser despedaçado em infinitas praças e avenidas (pausa - confere)

- onde foi que deixei os meus olhos?

- Calma... Graças a esse "acordo histórico", ingressamos, triunfalmente, no regime democrático. Campanha das "diretas já".

- eu não devia ter cabeceado a bola pra você

- é. ...veio na minha frente e eu chutei

- e foi aquilo, né

- é

- Foi gol

- Fazê o quê?... né

- aí não teve jeito, né: ganhamos

- e o pior é que a oposição NEM reagiu

- é eles podiam, ter ganhado esse jogo

- puxa!...o povo brasileiro bem que merecia...

- (pra platéia, consternados) desculpem 
A

- calma... vem por aqui (apalpa o caminho) por aqui... cuidado/ (chegam num ponto da diagonal. Ventríloquo e seu boneco)

- o acordo. E com vocês o vencedor no colégio eleitoral o Sr. Tancredo Neves!

Tancredo - Vamos, com a graça de Deus, presidir o momento histórico, e o faremos com a cooperação e participação de todas as forças políticas, econômicas e sociais bem-intencionadas, sem qualquer preocupação de represálias quanto ao passado.

A - vamos trair uma vez mais... vamos embrulhar uma democracia pra presente, pro povo brasileiro

Tancredo - (se chicoteando) Eu mereço. (tenta cantar) Quero falar de uma coisa/ Adivinha onde ela anda/ Deve estar dentro do peito/ ou caminha pelo ar. (deitando) Eu não merecia isso...

PORTARIA HOSPITAL.

Dr Tancredo de maca é interrogado pra fazer ficha de entrada

A

Tancredo - Tancredo de Almeida Neves.

A

Tancredo - Presidente do Brasil/ sou presidente(?)/ não sou? E além do mais devo estar morrendo/ (crescendo) se não sou presidente nem estou morrendo então chama alguém aqui pra falar comigo

A

Tancredo - como ficha?!

A

Tancredo - que hospital?

a - das clínicas

Tancredo - Brasília,... não...

A

- não, São Paulo 
Tancredo - Não, São Paulo, não. Diga-me só uma coisa: eu sou presidente, não sou?! (resiste em entregar a faixa presidencial)

A - senhor, senhor. (toma a faixa presidencial) Não. Quem assumiu foi o vice. A partir de agora seremos governados por uma dinastia de vices. Do vice viemos ao vice tornamos. A história se repete como farsa. (tom) É é esse o ponto

Busão.

- (inumerar lugares por onde o busão passa) ..., ..., ..., tem lugar ainda. Aceita cartão, passe, vale transporte...

- ei

- pera aí

- passa no...(um lugar perto de onde o espetáculo está)

- passa, não.

- então eu vou descer

- cuidado aí na frente

- é o que isso? Será

- é um enterro

- Credo em cruz

- é, até aí morreu o Neves

- é, morreu mesmo

- quem morreu

Mãe e filho

$\mathrm{F}$

M

$\mathrm{F}$
- Aha mãe. Aha. Olha lá um enterro

- sei meu filho. Fala baixo.

- Aha. Aha. Si fudeu (canta) o morto se fudeu/ só porque o morto morreu/ si fudeu, si fudeu/ antes ele do que eu (a mãe dá um tapa) ai ai ai mãe. Num bate nim eu... (canta) se fudeu... ai ai eu não (canta 
mais) se fudeu... se fudeu. Ai ai...ai tá tá tá quem é que se fudeu mãe

M - Morreu, meu filho. É o doutor Tancredo, meu filho: ele morreu

$\mathrm{F}$

M

$\mathrm{F}$

M

$\mathrm{F}$

M

- ... que que ele era, mãe antes de se fuder?

- ...olha... (procura) acho que não era nada. Oposição. Era oposição. Ou seja: nada. Mas agora ia virar presidente. Presidente.

- presidente é bom, mãe?

- Mas quê, só bão: é bão demais.

- Mãe, eu quero ser presidente quando crescer

- ah, meu filho, às vezes você parece idiota

\section{Na borda do círculo da bandeira}

A

- Eis aqui o ponto, que não é central, porque não há centros. Na verdade não é um ponto, é um circulo. o Brasil a um passo do futuro, que já vem, que já vem

C

- 1989, o passo colorido

- (cantam) esse é um país que vai pra frente - não vai haver poesia...

C

- teve um momento em que a história acabou, tinha ficado soterrada debaixo de um muro, que caiu, me parece, e quando foram aos escombros, lá estavam:

a - olhos, não um, mas dois. Dois olhos enterrados no pó

C

- um serve pra olhar o passado, outro o futuro

No centro da bandeira

O Anjo da História

C

- lá

a

- vendedor de que?

c

- sorvete e picolé

a

- estranho... 
C

- muito mais que estranho: você vai ver ó: lá vem ele

\section{o Vendedor Buzina}

a

- óóó-óólha o sorvete... óóólha o algodão doce. Puro açúcar

C

- ué! : mas não era sorvete

a

- é café que você quer,?: café tem aqui... vendo qualquer coisa, qualquer coisa que quiser. Só bugiganga

Narrador c - Mas diga lá se tem como eu enriquecer...

Sorveteiro - De toda forma e qualidade tem. Já vendi pau brasil, açúcar, tabaco, algodão, borracha, café, vendi ouro e pedras, mas agora não é mais pro meu bico... sabe como é né: consenso de Washington, se quiser uma coisinha diferente, tipo uma estatal, tem aqui. tá.

Narradoras - (cantam) E tem sabiá, tem canário e curió...

Elas vão se afastando, resmungando:

a - ou seja, e é nesse ou seja que reside toda a questão, tornei-me a Dita.

c - Numa era de nacionalismos bem constituídos querem te internacionalizar

\section{Jogo de cartas marcadas}

A

- Vamos continuar jogando?! ó... Tá aqui...: (gesto de jogar as cartas na mesa) Três motoqueiros mortos por dia nas ruas de São Paulo pela precarização do trabalho

C

- Rios e córregos soterrados pelo fomento da especulação imobiliária

A

- Tolerância zero com moradores de rua pela segurança pública

C - Filho da puta!

A

- Quantos você tem aí? 
A $\quad-492$

C - - Transporte coletivo deficitário pela produção de automóveis em massa

A - Bom; então: 7942 favelas com pobre vendo a riqueza e rico com medo da violência.

\section{$3^{\circ}$ tempo}

FUNK DO PROGRESSO

$\begin{array}{ll}\text { C } & \text { - Eu vou comprar } \\ \text { A } & \text { - Eu vou vender } \\ \text { A } & \text { - Eu vou mandar } \\ \text { Ambas } & \text { - Eu vou mandar um papo reto, } \\ & \text { essa vai para a galera } \\ & \text { Pela ordem e progresso } \\ & \text { Os home ficaram fera } \\ & \text { Sabe o que que aconteceu? } \\ & \text { Ééé não deu... } \\ & \text { Esses olhos meus e teus } \\ & \text { o medo a gente aprendeu }\end{array}$

c - Consumado o aprendizado do medo com o Golpe de 64, nos submetemos a essa implacável cadeia produtiva: produzir injustiça que produz violência que produz medo que produz trabalho.

\section{C sendo violentamente golpeada com um pau}

A

C

C

C

A

C
- Infeliz/ do país/ que precisa de heróis

- queria que vocês soubessem (cai)

- (levantando-se) A vida da gente acontece na... (pausa, dúvida) ...dentro da história. Uma história que a gente não sabe... (pausa, dúvida) ...não tem como saber como acaba. E que às vezes nem acaba

- Lavaram a rua!

- Dia novo, rua nova.

- Mesmo a poeira é outra. Nenhuma coisa fica nessa calçada, onde todo dia se compra o pão com o suor do rosto. 
A

C

A

C

A

C

A

C

Cantam

- Amanhece..

É o dia que vem

das entranhas da noite

nos avisar: (a e a $e$ a)

quase nada mudou

neste lugar,

enquanto for como é

o que foi inda é

o que foi inda é

enquanto for como é

Narrador - Agora vocês sabem alguns fatos, e bem triste é narrá-los; para quem os viveu, como então vivemos nós, e esta lembrança é índice atroz de terrores inesquecíveis.

C (canta) - Filhos da pátria Brasil! Filhos da dita...

Narrador - ...choro, não a dor da carne sendo torturada. Não o medo e o desespero. Choro de dor, mas não a dor desqualificada da fome. Não a dor da vida que se foi... e vai. Choro o ódio que o inimigo me fez 
sentir.

Ambas - Filhos da puta!

MÚSICA

Cantam

- Filhos da pátria Brasil! Filhos da dita

ou ...ou é... ou é

ou é . é . ou

FIM 
ANEXO C - LISTA DAS ESCOLAS PARTICIPANTES DA TEMPORADA EXPERIMENTAL DE Os filhos da Dita (março a junho/2011)

Cidade de São Paulo (incluindo região da cidade onde a escola está localizada, número de apresentações e público atingido)

MARÇo/2011 - Escolas contempladas pelo Projeto Geração AI-5 Os filhos da Dita:

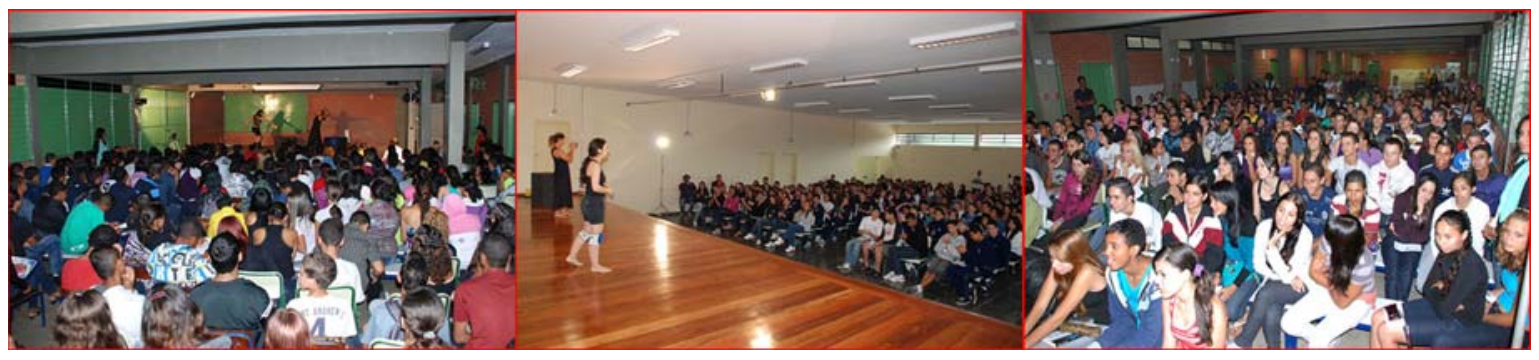

- ETEC PROF. APRÍgIo GONZAGA (Região Leste)

Foram realizadas 3 (três) apresentações na escola, perfazendo um total de 660 espectadores entre alunos e professores.

- E. E. PROFa . CARMELINDA MARQUES PEREIRA (Região Leste)

Foram realizadas 2 (duas) apresentações na escola, perfazendo um total de 523 espectadores entre alunos e professores.

- E. E. REPÚBLICA DA NICARÁGUA (Região Leste)

Foram realizadas 3 (três) apresentações na escola, perfazendo um total de 1052 espectadores entre alunos e professores.

- E. E. JARDIM LIMOEIRO III (Região Leste)

Foi realizada 1 (uma) apresentação na escola, perfazendo um total de 323 espectadores entre alunos e professores.

ABRIL - Escolas contempladas pelo Projeto Geração AI-5 - Os filhos da Dita:

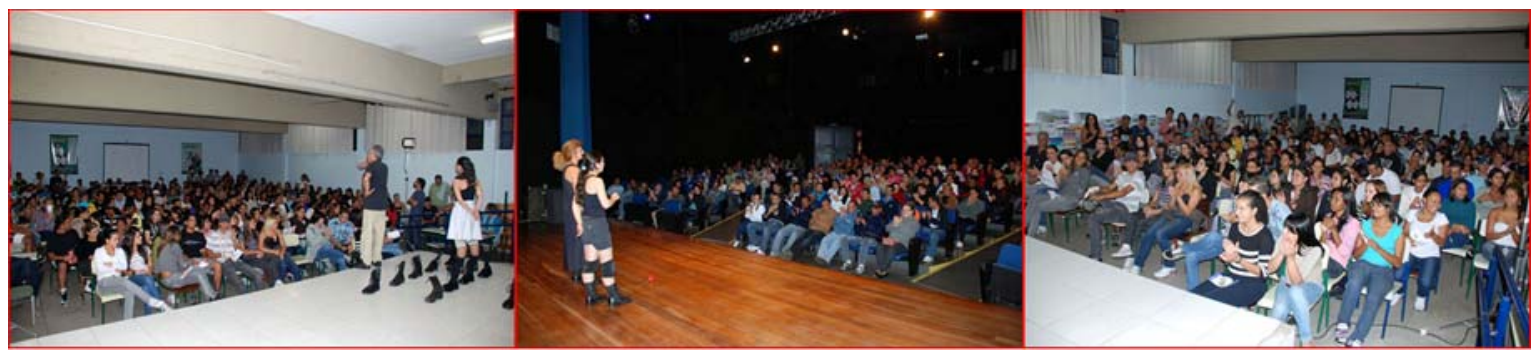

- E. E. DONA PILAR GARCIA VIDAL (Região Leste)

Foram realizadas 2 (duas) apresentação na escola, perfazendo um total de 642 espectadores entre alunos e professores. 
- E. E. PROFa. ZENAIde VIlalva DE ARAUjo (Região Norte)

Foram realizadas 2 (duas) apresentações na escola, perfazendo um total de 680 espectadores entre alunos e professores.

\section{- ESCOLA MUNICIPAL VEREADOR ANTONIO SAMPAIO (Região Norte)}

Foi realizada 1 (uma) apresentação na escola, perfazendo um total de 235 espectadores entre alunos e professores.

\section{- E. MUNICIPAL FREI GALVÃo (Região Norte)}

Foi realizada 1 (uma) apresentação na escola, perfazendo um total de 200 espectadores entre alunos e professores.

\section{- E. E. SENADOR ADOLFO GORDO (Região Oeste)}

Foi realizada 1 (uma) apresentação na escola, perfazendo um total de 120 espectadores entre alunos e professores.

\section{- E. E. MARTIM FRANCISCO (Região Sul)}

Foram realizadas 2 (duas) apresentações na escola, perfazendo um total de 760 espectadores entre alunos e professores.

MAIO - Escolas contempladas pelo Projeto Geração AI-5 - Os filhos da Dita:

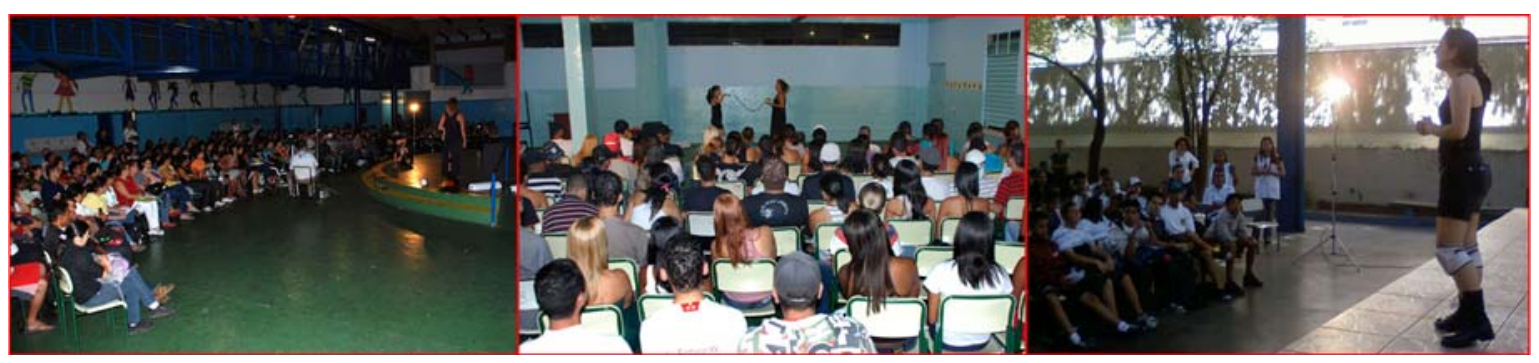

- CIEJA - SAPOPEMBA (Região Leste)

Foram realizadas 2 (duas) apresentações na escola (as apresentações ocorreram no CEU SAPOPEMBA), perfazendo um total de 552 espectadores entre alunos e professores.

- E. E. RECANTO VERDE SOL (Região Leste)

Foram realizadas 2 (duas) apresentações na escola, perfazendo um total de 300 espectadores entre alunos e professores.

- E. E. PEREIRA BARRETo (Região 0este)

Foram realizadas 3 (três) apresentações na escola, perfazendo um total de 1050 espectadores entre alunos e professores.

- E. E. BRASÍlIO MACHADO (Região Sul)

Foram realizadas 3 (três) apresentações na escola, perfazendo um total de 650 espectadores entre alunos e professores.

JUNHO - Escola contemplada pelo Projeto Geração AI-5 - Os filhos da Dita: 


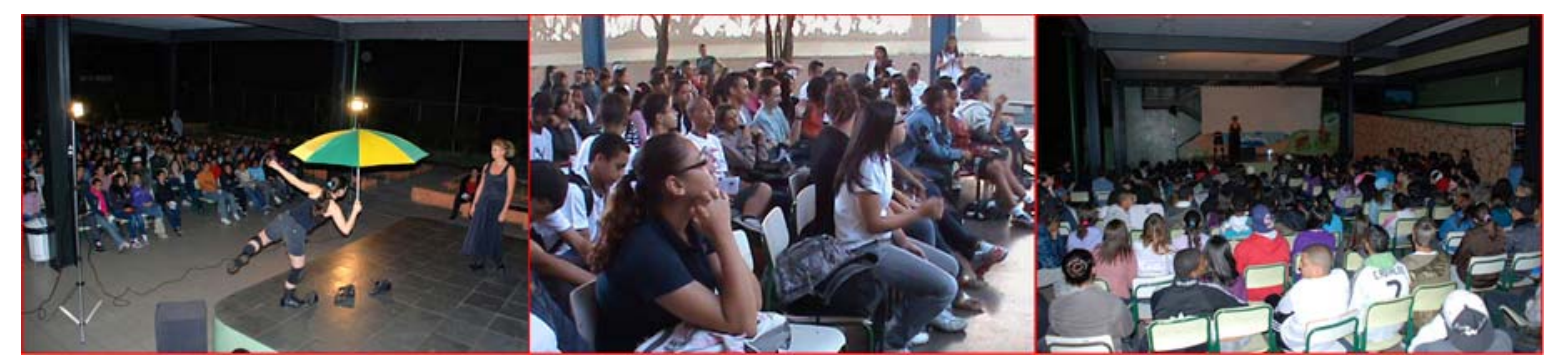

- E. E. ÂNGELO BoRtolo (Região Norte)

2 (duas) apresentações na escola, perfazendo um total de 1.202 espectadores entre alunos e professores.

RESUMO TOTAL DAS APRESENTAÇÕES NAS ESCOLAS:

(meses de Março / Abril / Maio e Junho de 2011)

TOTAL DE ESCOLAS CONTEMPLADAS $=15$

TOTAL DE APRESENTAÇÕES $=30$

TOTAL DE ESPECTADORES = 8.949

RESUMO DAS APRESENTAÇÕES POR REGIÃO DA CIDADE DE SÃO PAULO:

REGIÃO NORTE

Quantidade de apresentações $=6$

Quantidade de espectadores $=2.317$

REGIÃO SUL

Quantidade de apresentações $=5$

Quantidade de espectadores $=1.410$

REGIÃO LESTE

Quantidade de apresentações $=15$

Quantidade de espectadores $=4.052$

REGIÃO OESTE

Quantidade de apresentações $=4$

Quantidade de espectadores $=1.170$

TOTAL GERAL DE APRESENTAÇÕES $=30$

TOTAL GERAL DE ESPECTADORES = 8.949 